\title{
Hosts, Nesting Behavior, and Ecology of Some North American Spider Wasps (Hymenoptera: Pompilidae), II
}

\author{
Frank E. Kurczewski ${ }^{1, *}$, Glavis B. Edwards ${ }^{2}$, and James P. Pitts ${ }^{3}$
}

\begin{abstract}
This monograph is a continuation of a multiyear study of the genera and species of North American spider wasps (Pompilidae) and their spider host families, genera and species, nesting behavior, ecology, and natural communities. The study enlarges and enhances host preference, nesting behavior, and ecological information for 77 North American pompilid taxa. The first North American Pompilidae records for the families Tengellidae and Segestriidae, both from central coastal California, are reported herein. New host spider genera and species are listed for many of the pompilid species, including the first North American host record for Dipogon (Dipogon) g. graenicheri. The first detailed observations of male and female behavior in Arachnospila arcta are described.
\end{abstract}

\section{Introduction}

Pompilidae are long-legged, wing-flicking, highly active wasps that hunt for host spiders on the ground, on vegetation, on silken webs, and in water. The female spider wasp searches for and locates a suitable host spider, pursues it by running or in flight, subdues it with one or more venomous stings in the underside of its cephalothorax, usually transports it to a secretive location, eventually places it in a self-prepared or pre-existing nest, lays an egg on the spider's abdomen, closes the nest, and, sometimes, conceals the site. The egg hatches in a few days, and the wasp larva easily penetrates the spider's thin abdominal cuticle with its mandibles, consumes the edible portions of the host, grows relatively rapidly over several days, constructs a parchment-like cocoon, pupates, and emerges from the nest-site as an adult several weeks or a year later. The host spider must be of sufficient size to provide an adequate amount of food for the developing wasp larva. Large adult, penultimate, and subadult female spiders with a sizeable abdomen are the preferred host stages and sex for large spider wasp species, whereas small immature spiders are often captured and stocked as provisions by the small spider wasp species (Kurczewski and Edwards 2012; Kurczewski and Kiernan 2015; Kurczewski and Kurczewski 1968a, 1968b, 1972, 1973).

Many species in the tribe Pepsini build multi-celled nests underground or in series on plants or in aboveground cavities. Many species in the tribe Ageniellini construct mud cells above ground in concealed places and amputate most or all of the spider's legs at the coxa-trochanter joints before placing it in a cell. Species

\footnotetext{
${ }^{1}$ PO Box 15251, Syracuse, NY 13215. ${ }^{2}$ Curator, Arachnida and Myriapoda, Florida State Collection of Arthropods, FDACS, Division of Plant Industry, Gainesville, FL 32614-7100. ${ }^{3}$ Department of Biology, Utah State University, 5305 Old Main Hill, Logan, UT 84322.

*Corresponding author - fkurczewski@twcny.rr.com.
}

Manuscript Editor: Joseph Wilson 
of Pepsini and Ageniellini often prepare the depository before obtaining the spider. Many species of Pompilini capture their spider prey before excavating a singlecelled nest in the ground or other soft substrate. The majority of North American Pompilini (85\%) has a rake or comb on the forelegs for excavating a burrow in friable soil (Evans 1950, 1951a, 1951b; Kurczewski and Edwards 2012; Kurczewski and Kiernan 2015).

Evans and Yoshimoto (1962) presented the landmark paper on the ecology and nesting behavior of Nearctic pompilid wasps from the northeastern US. Krombein (1979) summarized host records and ecological information for the North American species in the family Pompilidae north of Mexico. More-recent host-record papers for the Nearctic species of Pompilidae include those by Kurczewski (1981), Wasbauer (1982), Kurczewski and Spofford (1986), Kurczewski et al. (1987), Wilson and Pitts (2007), Kurczewski (2010), Kurczewski and Edwards (2012), and Kurczewski and Kiernan (2015). Although nearly 3000 host records have been published for the $\sim 300$ North American species of Pompilidae, much remains to be learned about host selection and ecology of many of the species. Many pompilids, especially those with 2 or more generations per year living in woodlands, are much more polyphagous than previously believed and capture a multitude of cursorial-hunting and retreat-dwelling types of spiders (Kurczewski and Edwards 2012, Kurczewski and Kiernan 2015). Thus, any recent host record, even for a common species of pompilid, has the potential to be new.

\section{Methods}

This study, involving 77 North American taxa, is based on the observation, collection, and examination of $\sim 250$ spider wasps and their host spiders. Unlike the previous monograph on the same subject (Kurczewski and Edwards 2012) for a different set of spider wasp species, the present study is based mainly on online images and videos and accompanying descriptions made by numerous individuals. Subsequent emails or telephone conversations with these persons further expanded their field observations and descriptions and allowed us to present a more complete picture of the wasps' activities. The excellent photographs and videos and detailed observations provided by these persons were instrumental in aiding us in the identification of the spider wasp and host spider species. Such online images and videos, with associated predatory behavioral observations, immeasurably broadened the known host-spider species spectrum for many of the pompilid species.

Where field observations and actual collections were made, the spider wasps were hand-netted, freeze-killed, preserved, and labeled by the first author Frank E. Kurczewski (FEK) or his son, Keith E. Kurczewski (KEK). Females of Anoplius imbellis in New York State were hand-netted, brought inside and refrigerated for 10 minutes, identified, measured, taken back to the site of collection, and released live in the field. The spider wasp species were identified by the first and third authors or Matthias Buck (Royal Alberta Museum, Edmonton, AB, Canada: Dipogon sayi nigrior and Arachnospila f. fumipennis). The species of spider wasps are presented 
in taxonomic order following their arrangement in the family Pompilidae in the Catalog of Hymenoptera in America North of Mexico (Krombein 1979).

The paralyzed host spiders were collected, preserved in $70 \%$ alcohol, and labeled. Such spiders or online spider photographs were identified by the second author, Glavis B. Edwards, Robb Bennett (Royal British Columbia Museum, Victoria, BC, Canada: Amaurobiidae), David Bixler (Boreal Studies Research Labs, Tower, MN: Lycosidae), Kelly Kissane (Blinn College: Pisauridae), Joe Lapp (Instant Earth, Austin, TX: Eutichuridae), Robin Leech (University of Alberta, Edmonton, AB, Canada: Amaurobiidae, Araneidae, Liocranidae, Thomisidae), Laura Paxson (BugGuide [website]: Araneidae, Lycosidae), Darrell Ubick (California Academy of Sciences, San Francisco, CA: Lycosidae, Agelenidae, Anyphaenidae, Tengellidae), Rick West (Soothe, BC, Canada: Theraphosidae), and Chao Lun $\mathrm{Wu}$ (BugGuide [website]: Lycosidae). The families of spiders listed under the individual spider wasp species are arranged in taxonomic order following Platnick (2015).

The exact locality, date of collection and/or observation, collector or observer/ photographer, time of collection or observation, and type of habitat, if known, are delineated for each spider wasp-host spider record. The state, county, and exact location are alphabetized under each spider wasp species. Air and non-sand ground or sand surface temperature in degrees centigrade and behavioral descriptions are included for some of the spider wasp species. Body length of the wasp and spider, if measured, are given along with the species identification. The spider wasp specimens are deposited at Cornell University or Utah State University, and the spider specimens were given to Cornell University, Utah State University, or the Florida State Collection of Arthropods.

\section{Results}

\section{FAMILY POMPILIDAE}

\section{Subfamily PEPSINAE}

\section{Tribe Pepsini}

\section{Pepsis mildei Stål}

AZ: Cochise County, Huachuca Mountains, Miller Canyon; 9 July 2008; C.W. Melton. Host: Aphonopelma chalcodes Chamberlin (Theraphosidae) (Western Desert Tarantula) (Melton 2008; C.W. Melton, Hereford, AZ, 2016 pers. comm.).

CA: Los Angeles County, Altadena; 1 August 2009; A. Kiely. Host: Aphonopelma steindachneri (Ausserer). The wasp dragged the paralyzed tarantula backwards on the ground, grasping the base of its $2^{\text {nd }}$ left leg with her mandibles (Kiely 2009).

CA: San Diego County, San Diego, Naval Air Station Miramar; 14 July 1996, at dusk; R. Waayers. Host: Aphonopelma steindachneri (wasp, $\sim 30 \mathrm{~mm}$ ). The wasp dragged the paralyzed tarantula backwards across a road and into a hole in the ground (Waayers 2006). 


\section{Pepsis spp.}

TX: Cameron County, Bayview; 10 November 2007; D. Crispin. Host: Aphonopelma ?harlingenum (Chamberlin) (Harlingen Chocolate Brown Tarantula), adult or penultimate female. The wasp dragged the tarantula backwards, dorsal side upward, grasping the spider's left chelicera with her mandibles (Crispin 2007).

TX: Hidalgo County, Mission; 25 November 2008; R. Snider. Host: Aphonopelma ?anax (Chamberlin) (Texas Tan Tarantula), subadult female. The wasp dragged the tarantula backwards, dorsal side upward, grasping its right pedipalp with her mandibles. She dragged the spider from the middle of a paved road into a hole in the ground (Snider 2008).

TX: Hidalgo County, $7.2 \mathrm{~km}$ SW Mission, National Butterfly Center; 9 November 2013; 1642-1653 (CST); L.F. Cooper and G. Kessler. Host: Aphonopelma hentzi (Girard) (Texas Brown Tarantula), adult female. The A. hentzi female was first observed on the ground surface a short distance from the mouth of her burrow. She rapidly entered her burrow as a Pepsis sp. female searched nearby on the ground. The wasp likely followed a scent trail, probably using chemoreceptors on her antennae, leading eventually to the spider's burrow entrance, although other cues could have been involved, and chemical ecology studies are needed for spider wasps. After 1-2 minutes of searching in the vicinity, the wasp located the tarantula's entrance. The tarantula extended her front legs farther outward from her entrance as the wasp moved closer to the opening, perhaps sensing vibrations from the wasp's movements on the ground surface. The $A$. hentzi then exited her burrow, reared up on her hindlegs, raised her front legs in a threatening manner, and exposed her chelicerae (fangs) (Fig. 1). The wasp moved closer to the tarantula, examined

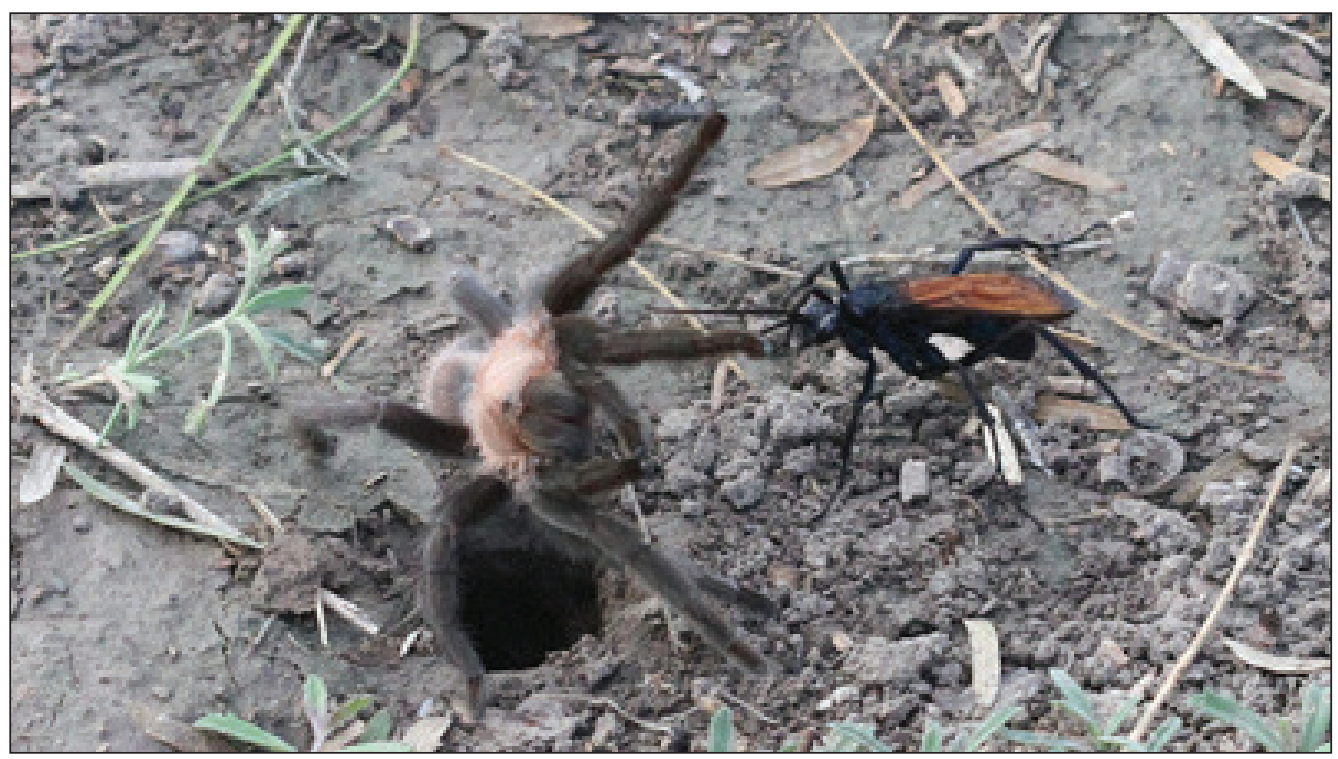

Figure 1. Aphonopelma hentzi adult female rears up on her hindlegs, raises her forelegs, and exposes her chelicerae (fangs) at the approach of a Pepsis sp. female (L.F. Cooper and G. Kessler, 2013 pers. comm.). 
it with her antennae, grasped it by a leg with her mandibles, released her grasp, and the 2 parried back and forth for several seconds. The wasp attempted to sting the spider at least 3 times during the back-and-forth interactions (Fig. 2). The spider made no attempt to bite the wasp but, instead, quickly turned away and ran through short grasses. The wasp followed, caught the spider, grasped it by a hindleg with her mandibles, braced her own hindlegs against the spider's pedipalps, turned it onto its back, and stung it in the underside of its cephalothorax. The spider's legs collapsed beneath its body as the wasp's venom took effect. The partly paralyzed tarantula acquiesced but rhythmically moved 3 of its legs. The wasp, perhaps bitten by the spider in the fray, slowly dragged her hindlegs on the ground, and then cleaned her face and antennae with her forelegs and mandibles. She continued to clean her face and antennae between periodic inspections of the spider (see Front Cover image). Eventually, the spider acquiesced totally at which time the wasp disappeared into a flowerbed with surrounding mulch surface cover (L.F. Cooper, Haines City, FL, and G. Kessler, Westborough, MA, 2013 pers. comm.).

\section{Priocnessus nebulosus (Dahlbom)}

WV: Greenbrier County, Ronceverte, overgrown lawn near deciduous woodland; 14 July 2014, 1550-1552 (EDT), $27^{\circ} \mathrm{C}$; FEK. Host: Agelenopsis sp. (Agelenidae), juvenile, $11.5 \mathrm{~mm}$ (wasp, $12.5 \mathrm{~mm}$ ). The wasp straddled the spider ventral side upward, grasped it with her mandibles by one or both chelicerae, and, retaining this grasp, walked forward across a lawn. The legs of the spider were not amputated by the wasp despite the cumbersome manner of prey transport (F.E. Kurczewski, 2014 pers. observ.).

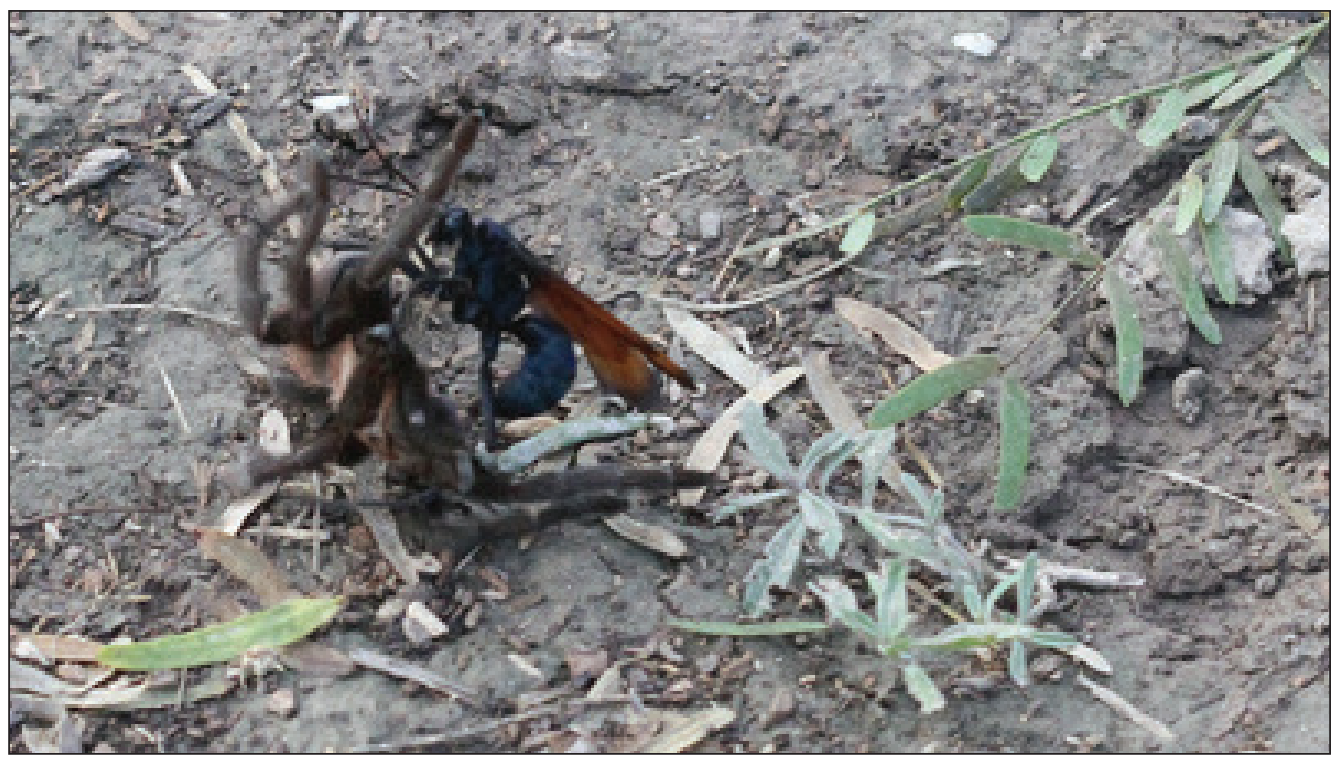

Figure 2. Pepsis sp. female turns an Aphonopelma hentzi adult female onto its side in an attempt to sting it in the underside of its cephalothorax (L.F. Cooper and G. Kessler, 2013 pers. comm.). 


\section{Entypus aratus (Townes)}

AZ: Cochise County, Texas Canyon, juniper savanna; 23 July 2013, 1633 (MDT), overcast; A.J. Abela and A. Schusteff. Host: Hogna carolinensis (Walckenaer) (Lycosidae) (Carolina Wolf Spider), adult female, $30 \mathrm{~mm}$ (wasp, $26 \mathrm{~mm}$ ). The wasp examined the recently paralyzed spider for several seconds with her mouthparts and antennae (see Front Cover image). The spider lay dorsal side upward with its legs folded underneath. The wasp then grasped the spider in that position by its right pedipalp or, alternately, in a ventral side upward position by the base of its left foreleg with her mandibles and dragged it backwards on the ground (Fig. 3; Abela 2013; A.J. Abela, Santa Maria, CA, and A. Schusteff, San Francisco, CA, 2013 pers. comm.; Schusteff 2013).

\section{Entypus fulvicornis (Cresson)}

AR: Washington County, Fayetteville; 7 July 2006; C.E. Trammel. Host: Rabidosa rabida (Walckenaer) (Rabid Wolf Spider), adult male, "large". The wasp grasped the spider's right front leg with her mandibles and proceeded slowly backwards, pulling it through tall grasses. She released the spider among the grasses and periodically examined it with her antennae before resuming transport (E. Trammel, Fayetteville, AR, 2014 pers. comm.).

TX: Collin County, Plano, Oak Point Park and Nature Preserve, abandoned field with tall grasses and forbs on a hillside; 1 July 2012; P. Assman. Host: Rabidosa rabida, adult female, $21.5 \mathrm{~mm}$ (wasp, $20 \mathrm{~mm}$ ). The wasp dragged the spider backwards across a path, grasping its left pedipalp with her mandibles (Fig. 4). She paused several times on the path, released her spider, walked in circles around it and in front of it, retrieved the prey, grasped it as before, and pulled it off the trail into high grasses (Assmann 2012; P. Assman, The University of Texas at Dallas, Richardson, TX, 2014 pers. comm.).

WV: Greenbrier County, Ronceverte, overgrown lawn near deciduous woodland; 13 July 2014, 1025-1040 (EDT), 23-24 ${ }^{\circ} \mathrm{C}$; FEK. Host: Dolomedes tenebrosus

Figure 3. Entypus aratus female grasps a paralyzed Hogna carolinensis adult female, ventral side upward, at the base of its left foreleg with her mandibles and attempts to drag it backwards on the ground (A. Schusteff, 2013 pers. comm.).

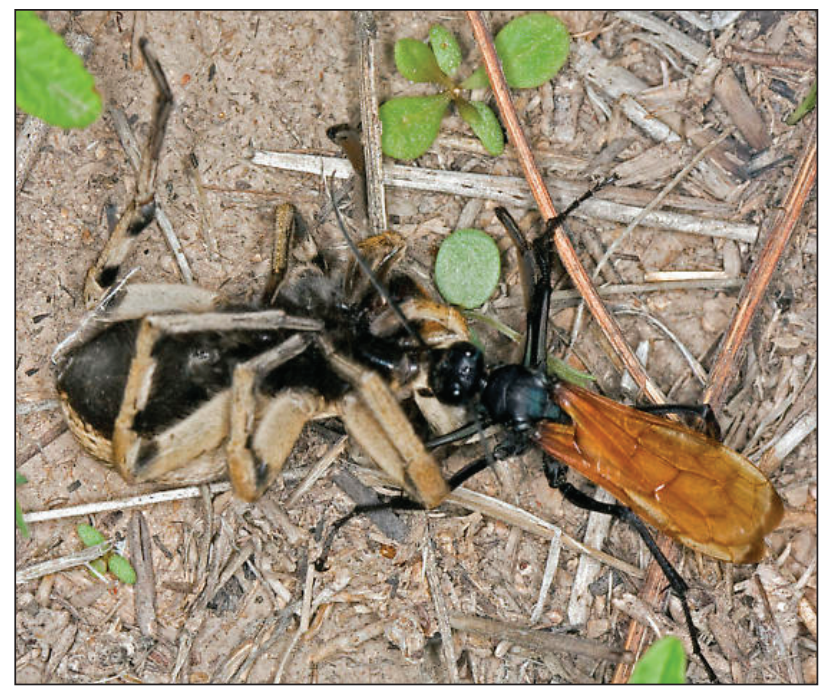


Hentz (Pisauridae) (Dark Fishing Spider), adult female, $26 \mathrm{~mm}$ ( $87 \mathrm{~mm}$ leg span) (wasp, $26 \mathrm{~mm}$ ). The wasp searched on the ground among high grasses at the edge of deciduous woodland, flicking her wings and tapping her antennae on the substrate. Fifteen minutes later, she dragged a large fishing spider backwards on the ground from the edge of the woodland, maintaining it in a dorsal side upward position while grasping a pedipalp with her mandibles. She abandoned the spider when chased by a Turdus migratorius L. (Turdidae) (American Robin; F.E. Kurczewski, 2014 pers. observ.).

\section{Entypus unifasciatus cressoni (Banks)}

NM: Otero County, Tularosa; 8 November 2009; R. Morris. Host: Hogna antelucana (Montgomery), adult female. The wasp examined the paralyzed spider's right chelicera and left pedipalp as it lay on its side, then grasped its right pedipalp with her mandibles and dragged it backwards on the ground (Morris 2009; R. Morris, Alamogordo, NM, 2014 pers. comm.).

\section{Entypus unifasciatus unifasciatus (Say)}

NY: Rockland County, Nyack to Haverstraw Trail; 19 July 2015; J. Lampkin. Host: Dolomedes tenebrosus, adult or penultimate female. The wasp dragged the paralyzed spider, dorsal side upward, backwards across dried leaves, plant litter, and stones, grasping its left pedipalp with her mandibles (see Front Cover image). She alternated between prey transport and releasing the spider on the ground, dorsal side upward, and flying ahead (Lampkin 2015; J. Lampkin, Suffern, NY, 2015 pers. comm.).

TX: [Northern] Liberty County, Big Thicket National Preserve, adjacent to a hiking trail, somewhat thick vegetation under a heavy canopy of large trees, and close to a small natural pond; 15 August 2009; J.M. Smith. Host: Dolomedes albineus Hentz (White-banded Fishing Spider), adult male. (Adult males of Dolomedes are usually smaller than the females and uncommon prey for this wasp species). The wasp

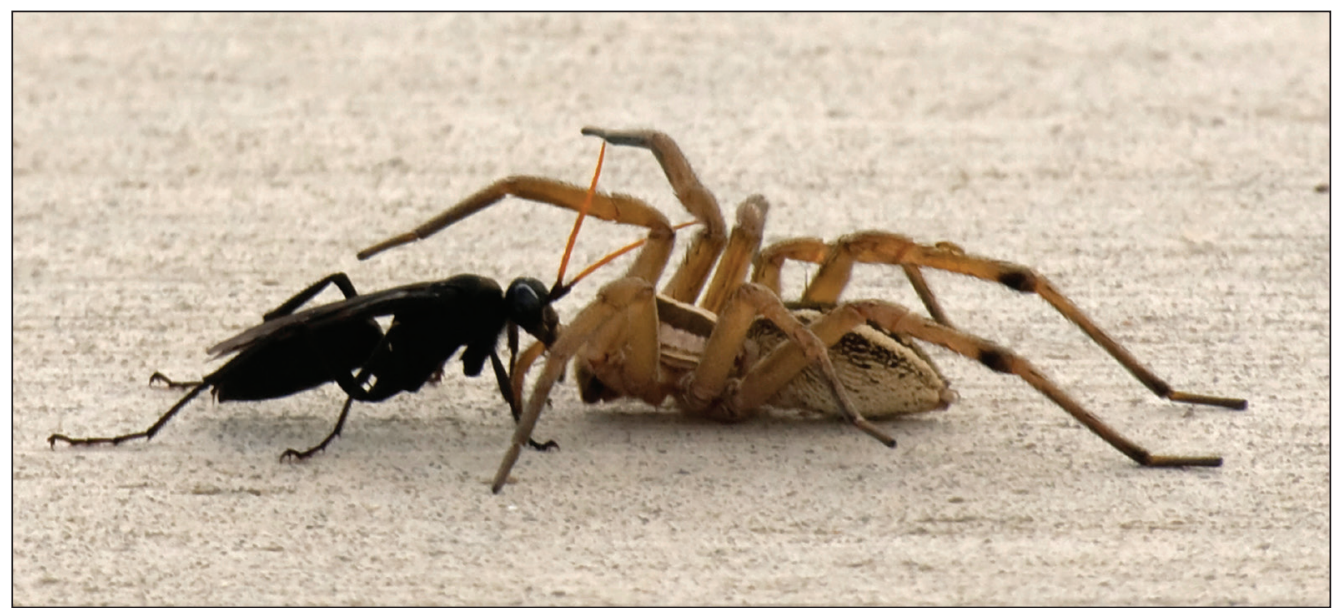

Figure 4. Entypus fulvicornis female drags a paralyzed Rabidosa rabida adult female, dorsal side upward, backwards across a path, grasping its left pedipalp with her mandibles (P. Assmann, 2014 pers. comm.). 
dragged the paralyzed spider rapidly backwards on the ground, dorsal side upward, grasping its right pedipalp with her mandibles (Fig. 5). The spider's long legs extended backwards and did not interfere with prey transport (Smith 2009; J.M. Smith, National Park Service, Big Thicket National Preserve, TX, 2014 pers. comm.).

WV: Greenbrier County, Ronceverte, overgrown lawn near deciduous woodland; 12, 14 July 2014, 1348, 1512 (EDT), 27-29 ${ }^{\circ} \mathrm{C}$; FEK. Host: Dolomedes tenebrosus, adult female, $22.5 \mathrm{~mm}$ (75 mm leg span) (wasp, $21 \mathrm{~mm}$ ); juvenile, 17.5 $\mathrm{mm}$ (58 $\mathrm{mm}$ leg span) (wasp, $18 \mathrm{~mm}$ ) (F.E. Kurczewski, 2014 pers. observ.).

A re-examination of 4 host spiders of $E$. u. unifasciatus from a previous study (Kurczewski and Edwards 2012; BugGuide 44748, 558852, pbase 116353825, jimmccormac.blogspot 2009/08) identified as Hogna sp. or Rabidosa sp. yielded the following revised tentative identifications: Tigrosa grandis (Banks), T. helluo (Walckenaer) (Field Wolf Spider), Rabidosa rabida, and T. ?georgicola (Walckenaer), respectively (L.L. Paxson, Williamstown, NJ, 2016 pers. comm.),

\section{Cryptocheilus attenuatus Banks}

IL: Champaign County, Rantoul, walking trail with tree cover near creek with sandy banks; 30 July 2014; J.P. Allen. Host: Alopecosa aculeata (Clerck) (Lycosidae), adult or subadult female, $10 \mathrm{~mm}$ (wasp, $12.5 \mathrm{~mm}$ ). The wasp dragged the

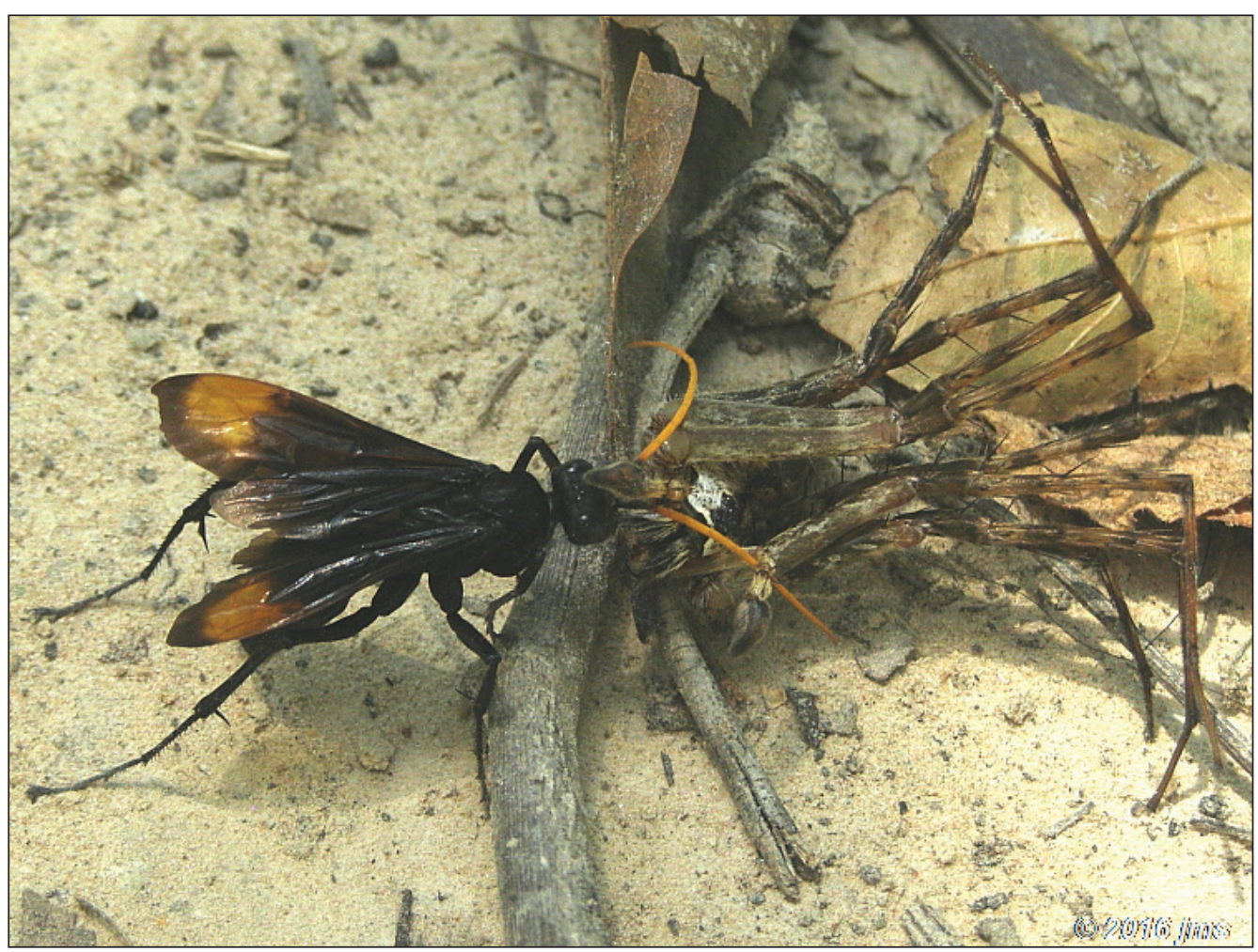

Figure 5. Entypus u. unifasciatus female drags a paralyzed Dolomedes albineus adult male, dorsal side upward, backwards on the ground grasping its right pedipalp with her mandibles (J.M. Smith, 2014 pers. comm.). 
spider backwards on rough ground, dorsal side upward, grasping its 2 nd left leg about midway from the end with her mandibles (Fig. 6). She eventually searched for a place to deposit the prey in openings on the sandy banks (Allen 2014; J.P. Allen, University of Illinois, Champaign, IL, 2015 pers. comm.).

\section{Priocnemis (Priocnemissus) minorata Banks}

AR: Washington County, Fayetteville; 1 May 2006; E. Trammel. Host: Schizocosa sp. (Lycosidae), subadult female. The wasp was noticeably larger (1.8 times longer in body length) than the spider. She inspected her paralyzed spider, which had been placed alternately in ventral and dorsal side upward positions on a dried leaf, with her antennae (Trammel 2006).

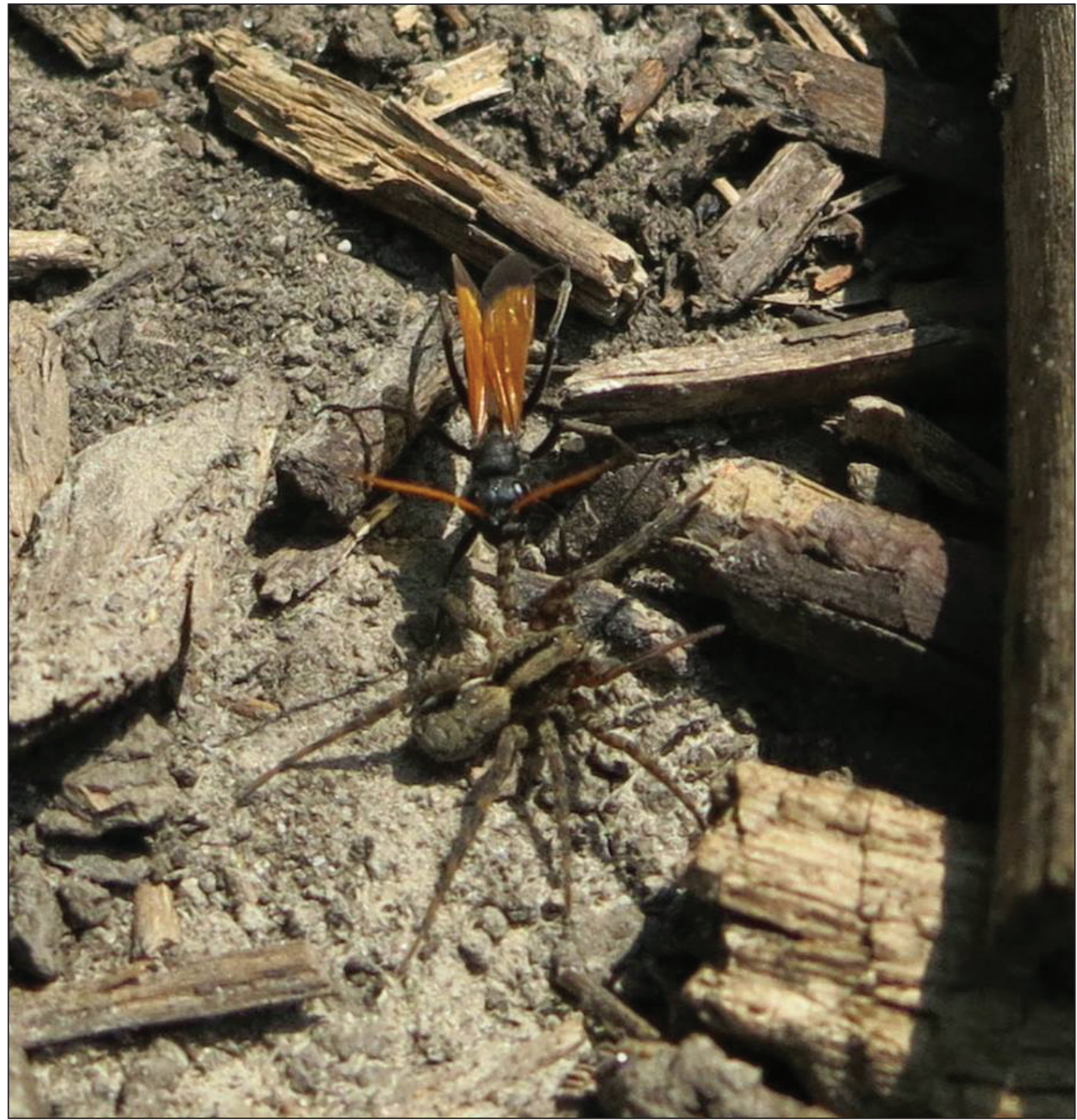

Figure 6. Cryptocheilus attenuatus female drags a paralyzed Alopecosa aculeata adult or subadult female, dorsal side upward, backwards on rough ground, grasping its $2^{\text {nd }}$ left leg about midway from the end with her mandibles (J.P. Allen, 2015 pers. comm.). 
IL: Cook County, Palos Park, McClaughry Springs Woods Forest Preserve; 26 April 2006; R. Curtis. Host: Trochosa terricola Thorell (Lycosidae) (Ground Wolf Spider). The wasp dragged the paralyzed spider backwards across fallen leaves, grasping the base of its $2^{\text {nd }}$ right leg with her mandibles while holding it upright in an almost vertical position. She released the spider periodically, dorsal side upward, and examined it with her antennae (R. Curtis, Chicago, IL, 2016 pers. comm.).

MA: Franklin County, Northfield, garden $6 \mathrm{~m}$ from woodland; 29 May 2016; C. Eiseman. Host: Trochosa ruricola (De Geer) (Rustic Wolf Spider), adult female (C. Eiseman, Northfield, MA, 2016 pers. comm.).

NE: Sarpy County, Bellevue, Fontenelle Forest; 17 April 2015; L. and B. Padelford. Host: Trochosa terricola, adult female. Two female wasps of about equal size fought vigorously over possession of the paralyzed spider, using their legs, mandibles, and stingers (Padelford and Padelford 2015).

NY: Onondaga County, Syracuse, Onondaga Hill, open deciduous woodland near swamp; 21 April-24 May 2014; 1044-1643 (EDT); 18-22 ${ }^{\circ}$ C; FEK. Hosts: Dysdera crocata C.L. Koch (Dysderidae) (Woodlouse Spider), juvenile, $11 \mathrm{~mm}$ (wasp, $12.5 \mathrm{~mm}$ ); Gladicosa gulosa (Walckenaer) (Lycosidae) (Forest Wolf Spider), adult female, 12.5, $13 \mathrm{~mm}$ (wasps, 12, $12.5 \mathrm{~mm}$ ); Pisaurina mira (Walckenaer) (Pisauridae) (Nursery Web Spider), penultimate female, $14.5 \mathrm{~mm}$ (wasp, 13 $\mathrm{mm}$ ); Wadotes hybridus (Emerton) (Amaurobiidae), adult female, $11.5 \mathrm{~mm}$ (wasp, $12.5 \mathrm{~mm}$ ), with left foreleg missing beyond coxa-trochanter joint (F.E. Kurczewski, 2014 pers. observ.).

NY: St. Lawrence County, Piercefield, Massawepie Mire; 1 June 2014; J. Gluth. Host: Arctosa ?rubicunda (Keyserling) (Lycosidae), immature female. The wasp dragged the spider backwards across a dirt road leading through a bog, grasping the base of its hindleg with the mandibles and holding it dorsal side upward at a nearly $45^{\circ}$ angle (Gluth 2014).

NY: Suffolk County, Heckscher State Park; 27 April 2013; R. Kelly. Host: Trochosa sp., adult female (wasp, 12-13 mm long). The wasp dragged the spider backwards on the ground, holding it in an upright vertical position while grasping the base of its left $? 3^{\text {rd }}$ leg with her mandibles (Kelly 2013).

ND: Grand Forks County, Turtle River State Park; 2 June 2012; C.D. Barrentine. Host: ?Clubiona sp. (Clubionidae), ?10 mm (wasp, 11-13 mm). The wasp grasped the spider by the base of a hindleg and transported it backwards while holding it in an upright perpendicular position. The wasp moved at the speed of " $10 \mathrm{~cm} / \mathrm{sec"} \mathrm{on}$ the rough bark at the base of a large oak tree (Barrentine 2012).

VA: City of Richmond, Powhite Park; 16 April 2015; J. Shelton. Host: Pisaurina mira, penultimate male. The wasp transported the paralyzed spider backwards, grasping the base of a leg, often the $3^{\text {rd }}$ right leg, with her mandibles (Shelton 2015).

WV: Greenbrier County, Ronceverte, open deciduous woodland; 13-14 April 2014, 9 April 2016; FEK. Hosts: Gladicosa gulosa, adult male, 10.5, $11 \mathrm{~mm}$ (wasps, 13, $12.5 \mathrm{~mm}$ ); Hogna frondicola (Emerton) (Adirondack Wolf Spider), adult female, $11.5 \mathrm{~mm}$ (wasp, $13 \mathrm{~mm}$ ); Wadotes hybridus (Amaurobiidae), adult male, $10.5 \mathrm{~mm}$ (wasp, $13 \mathrm{~mm}$ ) (F.E. Kurczewski, 2014 pers. observ.). 
WV: Upshur County, near Ruraldale (elevation, $330 \mathrm{~m}$ ), open oak-hickory forest; 4 June 2010; S. Creswell. Host: Coras sp., possibly juvenilis (Keyserling) (Amaurobiidae). The wasp pulled the spider backwards, dorsal side upward, grasping the base of its left foreleg with her mandibles (Creswell 2010; S. Creswell, Buckhannon, WV, 2014 pers. comm.).

WV: Upshur County, near Ruraldale; 15 April 2012; S. Creswell. Host: Pardosa sp. (Lycosidae), adult or penultimate male. The wasp dragged the spider backwards across leaves in woodland, grasping the base of its right $3^{\text {rd }}$ or $4^{\text {th }}$ leg with her mandibles while holding it in an upright perpendicular position (Creswell 2012a).

ON, CANADA: Regional Municipality of Waterloo, Cambridge; 13 May 2016; A. Neuman. Host: Schizocosa sp.. adult female. The wasp pulled the paralyzed spider backwards on the ground in woodland, dorsal side upward, grasping its right forefemur with her mandibles (Neuman 2016).

\section{Priocnemis (Priocnemissus) oregona Banks}

OR: Benton County, just north of Corvallis; 9 June 2011; J. Pearson. Host: Antrodiaetus sp. (Antrodiaetidae) (folding door spider), subadult female. The wasp examined the paralyzed spider, which laid dorsal side upward on the ground (see Front Cover image; Pearson 2011; J. Pearson, Corvallis, OR, 2015 pers. comm.).

OR: Coos County, South Slough Estuarine Sanctuary, mossy earthen bank; 26, 28 March 2015; D. and E. Paulson. Host: Antrodiaetus sp., adult female, juvenile, $15,10 \mathrm{~mm}$ (wasp, $15 \mathrm{~mm}$ ). The female dragged paralyzed spiders backwards on the ground, either dorsal or ventral side upward. She grasped them with her mandibles by the base of a foreleg, hindleg, or spinnerets while ascending the steep bank. During one provisioning trip, she was pestered by a small conspecific male attempting to mate. The female attempted unsuccessfully to pull one spider "broadside" into her perfectly circular burrow entrance, grasping the base of its $2^{\text {nd }}$ left leg with her mandibles, but, then, turned around and, backed in holding the spider's spinnerets with her mandibles. Two days later the wasp entered the same hole in the ground, thereby confirming that this species makes a bi- or multi-celled nest with a single entrance (Paulson and Paulson 2015; D. and E. Paulson, Roseburg, OR, pers. comm. 2015).

OR: Douglas County, Elkton; 25 May 2008; P. Huntley-Franck. Host: Antrodiaetus sp. The wasp grasped the paralyzed spider by its right hindleg with her mandibles and pulled it backwards on the ground, holding it in an almost perpendicular position (Huntley-Franck 2008).

OR: Douglas County, Elkton; 5 April 2009; P. Huntley-Franck. Host: Antrodiaetus sp., adult female, $15 \mathrm{~mm}$ (wasp, $12.5 \mathrm{~mm}$ ). The wasp dragged the paralyzed spider backwards on the ground, grasping the base of its left hindleg with her mandibles and holding it in a nearly upright perpendicular position. Several other $P$. oregona females at this locality were observed searching for host spiders in a leaf-covered grassy area in a backyard (Huntley-Franck 2009).

OR: Multnomah County, Portland, Forest Park, woodland; 19 April 2016; $29{ }^{\circ} \mathrm{C}$; KEK. Host: Antrodiaetus sp., adult female. The wasp grasped the spider with her 
mandibles and pulled it backwards, releasing it ventral side upward on the ground (K.E. Kurczewski, Portland, OR, 2016 pers. comm.).

\section{Priocnemis (Priocnemis) cornica (Say)}

IL: Putnam County, Hennepin Township, Dixon Waterfowl Refuge at Hennepin and Hopper Lakes; 25 September 2016; S. Ivanov. Host: Anyphaena sp. (Anhyphaenidae) (ghost spider), adult or subadult female, 5-6 mm (wasp, 5-6 mm). The wasp pulled her paralyzed spider into a previously prepared burrow in an empty sand lot. Several larger Episyron quinquenotatus females were nesting nearby (Ivanov 2016a).

NY: Onondaga County, Syracuse, Onondaga Hill, silt loam soil near garage foundation; 10 October 2014, 31 May 2016, 1102-1342 (EDT), 13-25 ${ }^{\circ} \mathrm{C}$; FEK. Host: Pardosa moesta Banks, subadult female, $5 \mathrm{~mm}$ (wasp, $6 \mathrm{~mm}$ ); Philodromus sp. (Philodromidae), immature, $5.5 \mathrm{~mm}$ (wasp, $7 \mathrm{~mm}$ ). The wasp grasped the $P$. moesta by the base of a hindleg with her mandibles and, holding it in an upright perpendicular position, walked backwards (F.E. Kurczewski, 2014, 2016 pers. observ.).

ON, CANADA: Northumberland County, Brighton, sandy soil of backyard; 28 August 2008, 1158-1203 (EDT); N. Smith. Host: Trochosa ruricola or T. terricola, adult female, $8 \mathrm{~mm}$ (wasp, $9 \mathrm{~mm}$ ). The wasp grasped the spider with her mandibles midway on its right foreleg or base of left pedipalp and dragged it, dorsal side upward, backwards toward her burrow entrance (Fig. 7). She attempted unsuccessfully

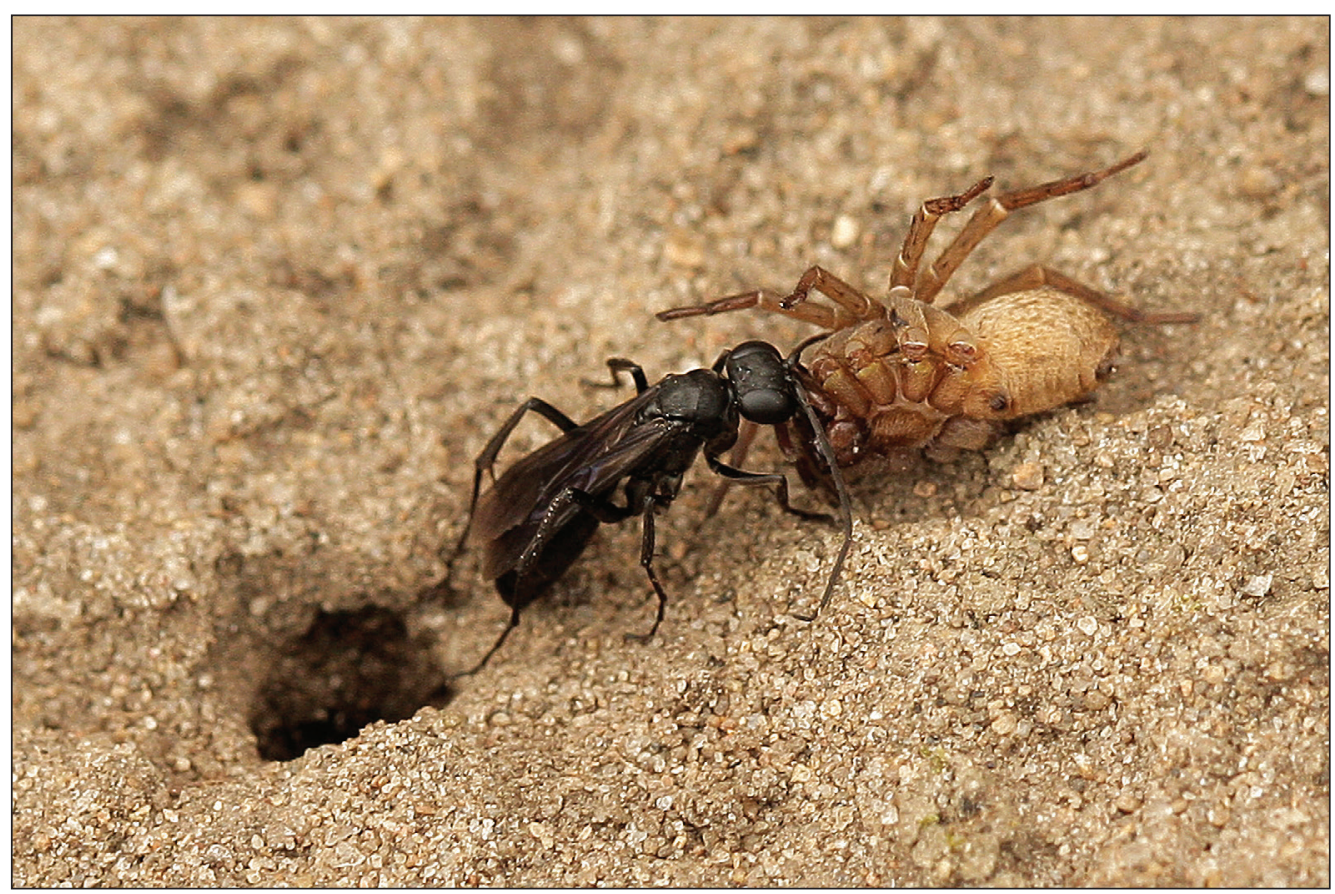

Figure 7. Priocnemis cornica female drags a paralyzed Trochosa ruricola or T. terricola adult female backwards on the ground toward her open burrow, grasping its left pedipalp with her mandibles (N. Smith, 2013 pers. comm.). 
to stuff the spider into the burrow from the outside without first entering the opening (Fig. 8). Other females nesting nearby turned around inside the opening and grasped the spider by its spinnerets with the mandibles before backing down the burrow (Smith 2008; N. Smith, Brighton, ON, Canada, 2013 and 2014 pers. comm.).

ON, CANADA: Northumberland County, Brighton, sandy soil of backyard, 21 September 2009; N. Smith. Host: ?Agroeca sp. (Liocranidae), adult female. The wasp examined the paralyzed spider as it laid dorsal side upward on sandy soil (Smith 2009a; N. Smith, 2013, pers. comm.).

\section{Priocnemis (Priocnemis) germana (Cresson)}

NH: Coos County, Dummer; 9 August 2011; T. Murray. Host: Cheiracanthium sp. (Eutichuridae), penultimate male. Two conspecific wasps contested the possession of this prey, each attempting to pull the spider in a different direction. Eventually, one of the wasps stopped pulling on the spider and flew away. The other wasp grasped the base or farther out on the spider's $3^{\text {rd }}$ right leg with her mandibles and dragged it sideways and backwards over leaves and other debris (Murray 2011).

NY: Onondaga County, Syracuse, Onondaga Hill, open deciduous woodland near swamp; 4-5 July, 7 September 2015; FEK. Host: Pisaurina mira, immature,

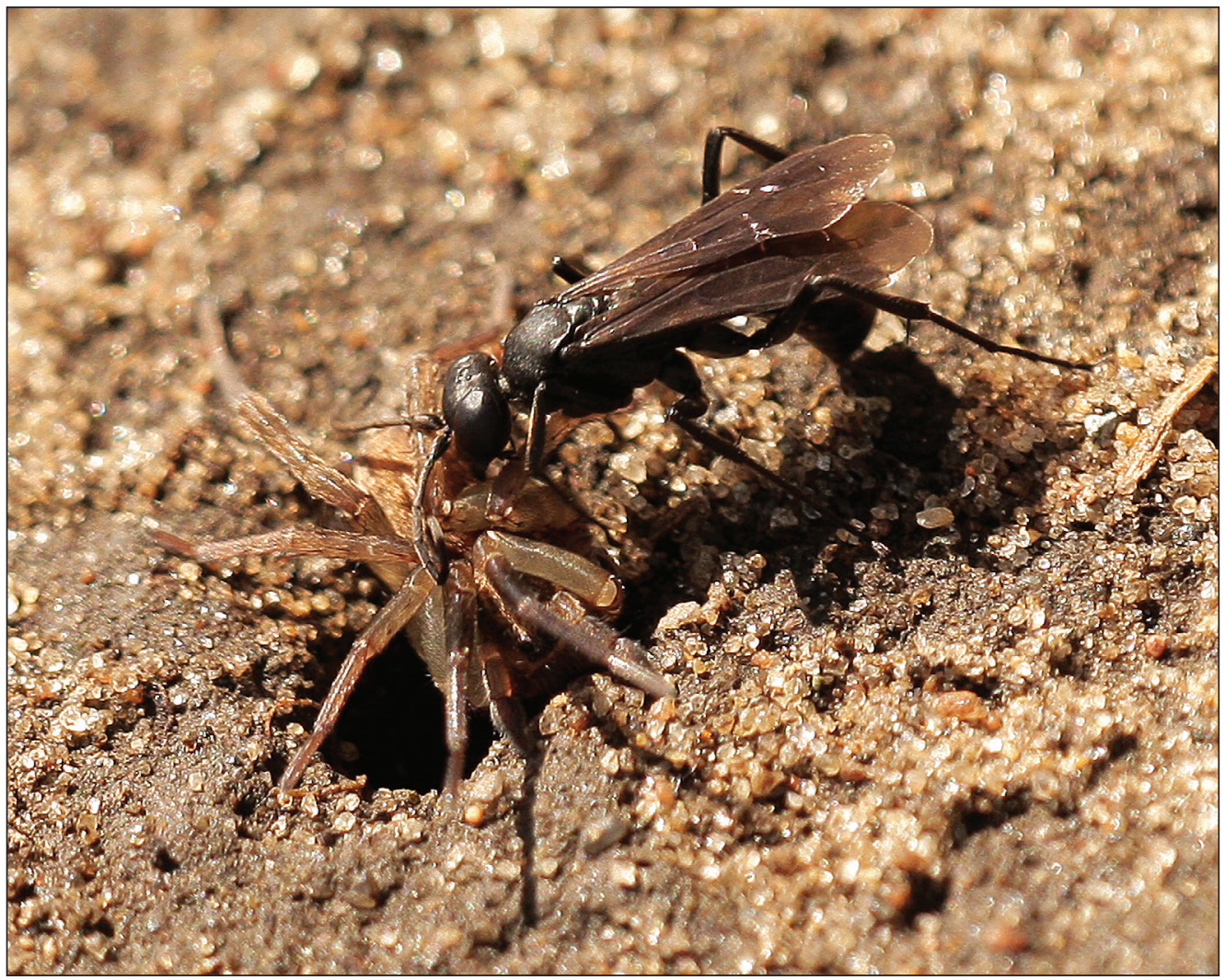

Figure 8. Priocnemis cornica female attempts to stuff a paralyzed Trochosa ruricola or T. terricola adult female into her burrow abdomen $1^{\text {st }}$, maintaining her grasp of its left hindleg with her mandibles (N. Smith, 2013 pers. comm.). 
$9.5 \mathrm{~mm}$ (wasp, $10 \mathrm{~mm}$ ); Cheiracanthium inclusum (Hentz) (Yellow-sac Spider) or C. mildei C.L. Koch (Black-footed Spider), penultimate male, $6.5 \mathrm{~mm}$ (wasp, 7.5 $\mathrm{mm}$ ); Herpyllus ecclesiasticus Hentz (Gnaphosidae) (Eastern Parson Spider), adult female, $9 \mathrm{~mm}$ (wasp, $9 \mathrm{~mm}$ ) (F.E. Kurczewski, 2015 pers. observ.).

\section{Priocnemis (Priocnemis) notha notha (Cresson)}

NY: Onondaga County, Syracuse, Onondaga Hill, loamy soil at edge of lawn; 10 October 2014, 1316 (EDT), $14{ }^{\circ} \mathrm{C}$; FEK. Host: Cheiracanthium inclusum or C. mildei, penultimate male, $7.5 \mathrm{~mm}$ (wasp, $8 \mathrm{~mm}$ ). The wasp dragged the spider backwards on the ground, grasping the base of a hindleg with her mandibles while maintaining it in an almost upright perpendicular position (F.E. Kurczewski, 2014 pers. observ.).

\section{Priocnemis (Priocnemis) scitula relicta Banks}

NY: Onondaga County, Syracuse, Onondaga Hill, open deciduous woodland; 16 July-23 August 2014, 13 September 2015; FEK. Hosts: Cheiracanthium sp., immature, $4 \mathrm{~mm}$; Xysticus sp. (Thomisidae), immature, $4 \mathrm{~mm}$; Platycryptus undatus (De Geer) (Salticidae) (Tan Jumping Spider), immature $5 \mathrm{~mm}$; (Salticidae), immature, $4.5 \mathrm{~mm}$; (Salticidae), adult male, $5 \mathrm{~mm}$ (wasps, 6, 7, 7, 7, $6.5 \mathrm{~mm}$ ) (F.E. Kurczewski, 2014 and 2015 pers. observ.).

\section{Caliadurgus fasciatellus alienatus (Smith)}

IA: Carroll County, Hobbs Conservation Area; 14 July 2016; E. Miller. Host: Araneidae sp., penultimate male. The wasp carried the paralyzed spider, ventral side upward, on a recently mowed walking path. She grasped the spider by the base of its $2^{\text {nd }}$ left leg with her mandibles and alternated walking or flying forward for $\sim 2 \mathrm{~m}$ (Miller 2016).

NJ: Camden County, Atco; 24 September 2010; Y. Alexander. Host: Larinia directa (Hentz) (Araneidae), subadult female. The wasp grasped the spider by the base of its $3^{\text {rd }}$ left leg during prey transport and held it in a quasi-dorsal side upward position (Alexander 2010).

OH: Greene County, Sugarcreek Township, Sweet Arrow Reserve; 23 September 2015; T. Turner. Host: Metepeira labyrinthea (Hentz) (Araneidae) (Labyrinth Orbweaver), adult female. The wasp captured the spider in the center of its web. She stung it, flew a "short distance" with it to the top of a leaf, and suspended it in mid-air from the bottom of the leaf, using threads from its spinnerets. The wasp flew away, returned to the top of the leaf a few minutes later, and walked over the spider (Turner 2015).

\section{Dipogon (Deuteragenia) calipterus calipterus (Say)}

PA: Bucks County, Washington Crossing; 20 August 2016; S.J. Ausubel. Host: Xysticus sp., penultimate male, $5 \mathrm{~mm}$ (wasp, $8 \mathrm{~mm}$ ). The wasp dragged the paralyzed spider backwards, grasping its spinnerets with her mandibles (Ausubel 2016; S.J. Ausubel, Forest Hills, NY, 2016 pers. comm.). 


\section{Dipogon (Deuteragenia) papago anomalus Dreisbach}

WV: Greenbrier County, Ronceverte; 14 July 2014, 1136 (EDT); $26{ }^{\circ} \mathrm{C}$; FEK. Host: Callobius bennetti (Blackwall) (Amaurobiidae) (Hacklemesh Weaver), immature, $7 \mathrm{~mm}$ (wasp, $8.5 \mathrm{~mm}$ ). The wasp captured her spider in nearby deciduous woodland and nested among stacked wood in a predominantly oak-hickory woodpile (F.E. Kurczewski, 2014 pers. observ.).

\section{Dipogon (Deuteragenia) pulchripennis (Cresson)}

MA: Barnstable County, Cape Cod, Chatham; 12 July 2015; C. Wilson. Host: Platycryptus undatus, adult male. The wasp dragged the paralyzed spider across a porch deck by the base of its $2^{\text {nd }}$ right leg and by its spinnerets with her mandibles. The spider was 1.25 times longer and considerably heavier than the smaller and lighter wasp (Wilson 2015; C. Wilson, Toledo, OH, 2015 pers. comm.).

NY: Onondaga County, Syracuse, Onondaga Hill, edge of open deciduous woodland; 15 September 2014, 4 July 2015, 1403-1621 (EDT), 21-24 ${ }^{\circ} \mathrm{C}$; FEK. Host: Platycryptus undatus, penultimate female, juvenile, 9.5, 9, $7 \mathrm{~mm}$ (wasps, 9.5, 9, $8.5 \mathrm{~mm}$ ) (F.E. Kurczewski, 2014 and 2015 pers. observ.).

\section{Dipogon (Deuteragenia) sayi nigrior Townes (det. M. Buck)}

AB, CANADA: Halfmoon Natural Area, sandy soil with Pinus banksiana Lamb. (Jack Pine), (Reindeer Lichen), and bearberry; 17 June 2013; A. Thysse;. Host: Xysticus sp., adult female. The wasp walked backwards with the spider on and around fallen branches and other debris, retaining her grasp of its spinnerets with her mandibles (see Front Cover image). She paused frequently to examine the paralyzed prey. At no time did she fly or attempt to fly with her relatively large spider. The $1^{\text {st }}$ and $2^{\text {nd }}$ left legs of the spider were amputated at the coxa-trochanter joints (Thysse 2013a; A. Thysse, Edmonton, AB, Canada, 2013 pers. comm.).

\section{Dipogon (Deuteragenia) sayi sayi Banks}

MD: Montgomery County; 1 July 2015; E. Dankowicz. Host: Xysticus sp., adult female. The wasp pulled the paralyzed spider backwards across the substrate, grasping its spinnerets with her mandibles (Dankowicz 2015a).

\section{Dipogon (Dipogon) graenicheri graenicheri Banks}

FL: Lake County, Ferndale, Ferndale Preserve; 19 February 2016; O. Davids. Host: Anasaitis canosa (Walckenaer) (Salticideae) (Twinflagged Jumping Spider), adult female. A series of 4 photographs shows the wasp walking backwards on sand and debris, grasping the paralyzed spider by its spinnerets with her mandibles (Hobo Joe A.K.A. Insect Lover 2016).

\section{Tribe Ageniellini}

\section{Phanagenia bombycina (Cresson)}

IA: Pottawattamie County, Crescent, Hitchcock Nature Area; 9 July 2013; L. and B. Padelford. Host: Rabidosa rabida, subadult female, with all but 2 of the 
spider's legs on the left side cut off at coxa-trochanter joints. The wasp carried the spider forward along a sharp cut in an earthen bank, dorsal side upward, grasping its right chelicera with her mandibles. The wings assisted in forward transport of the spider when ascending the bank. The wasp disappeared into a crevice in the bank (Padelford and Padelford 2013).

NC: Durham County, Durham, Parkwood, leaf litter in deciduous woodland; 17 August 2014; P. Cotinis. Host: Lycosidae, adult or subadult female (wasp, $12 \mathrm{~mm}$ ), all legs except the right foreleg cut off at coxa-trochanter joints. The wasp grasped the spider, dorsal side upward but tilted on its side, and walked forward, holding it by its right chelicera. She held her wings flat on the dorsum (Cotinis 2014).

PA: Lebanon County, Annville; 21-25 September 2013; N. Elhardt. Two females periodically visited a cluster of 12 light grayish-tan cells affixed to the underside of a $30-\mathrm{cm}^{2}$ piece of slate near the base of an outbuilding (summer kitchen) (Fig. 9). The nesting site was surrounded by lawn, other outbuildings, a woodlot, and agricultural fields. The cells were old and had wasp-emergence openings at one end. They were oriented in various oblique positions (Fig. 9). The cell material consisted of hard inorganic "mud" of a clayey-silt composition. The 12 cells averaged 15.75 (range: 15-18) $\mathrm{mm}$ long and 7.96 (range: 7-8.5) $\mathrm{mm}$ wide at the middle (N. Elhardt, Annville, PA, 2013 pers. comm.).

WV: Greenbrier County, Ronceverte, gravel driveway through overgrown lawn; 13 July 2014, 1051-1121 (EDT), 23-25 ${ }^{\circ} \mathrm{C}$; FEK. Host: Alopecosa kochi (Keyserling), penultimate male, $12 \mathrm{~mm}$ (wasp, $12.5 \mathrm{~mm}$ ), with all legs except the

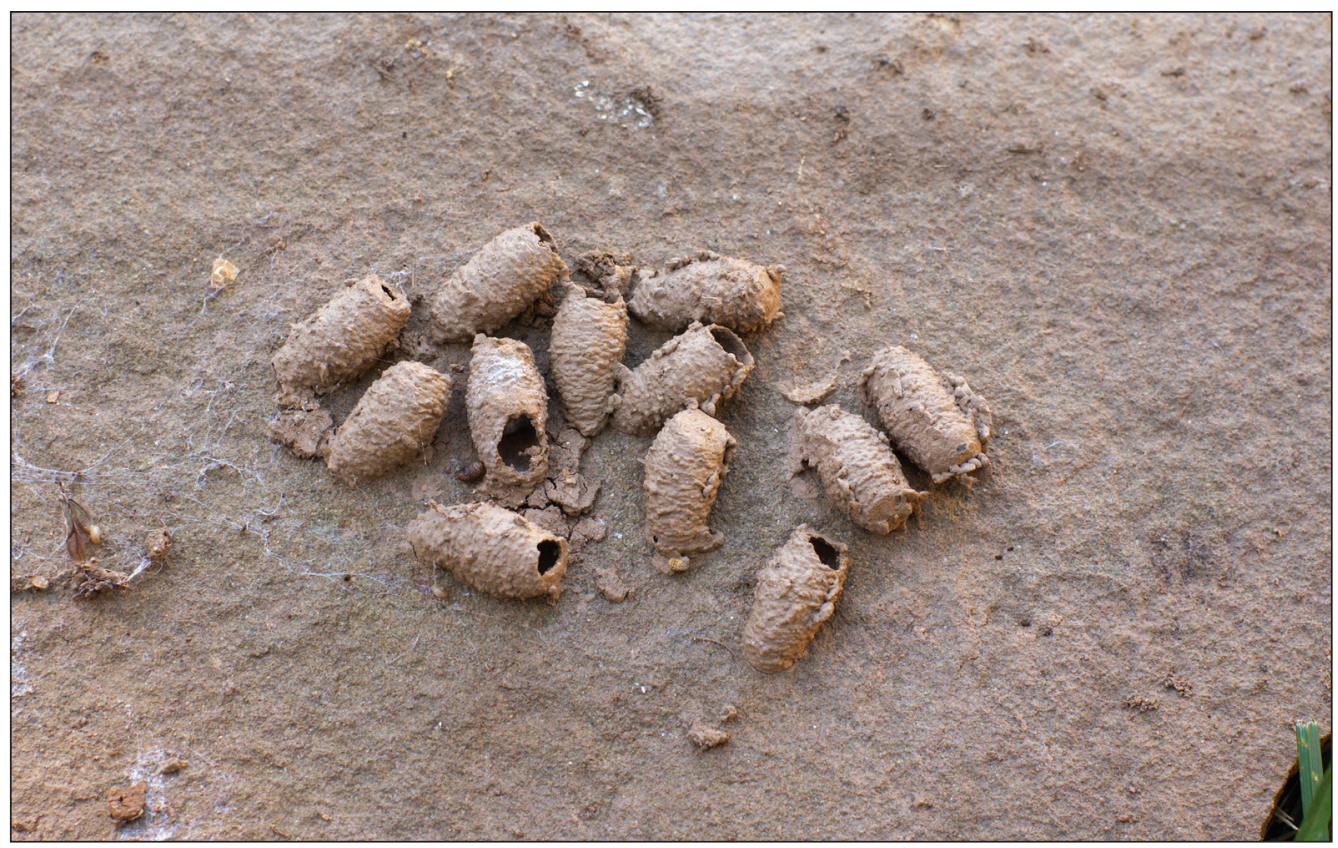

Figure 9. Cluster of 12 old Phanagenia bombycina cells affixed to underside of slate slab near base of an outbuilding. The $P$. bombycina emergence holes occupy the ends of the mud cells (N. Elhardt, 2013 pers. comm.). 
right foreleg cut off at the coxa-trochanter joints. The wasp searched through high grasses for several minutes walking slowly forward, tapping her antennae on the substrate, and holding her wings flat on the dorsum. Twenty minutes later, she ran forward across a gravelly driveway holding a paralyzed wolf spider underneath, dorsal side upward and face forward. She grasped the spider's left pedipalp or chelicera with her mandibles. The hollowed-out carcass of another penultimate male A. kochi, $11 \mathrm{~mm}$ long, was recovered from a mud cell, $16 \mathrm{~mm}$ long and $8 \mathrm{~mm}$ wide at its widest point, presumably made by this species beneath a flat stone at the edge of a garden (F.E. Kurczewski, 2014 pers. observ.).

\section{Auplopus architectus architectus (Say)}

MD: Montgomery County; 3 July 2015; E. Dankowicz. Host: Trachelas tranquillus (Hentz) (Trachelidae) (Broad-faced Sac Spider), penultimate female, with all legs cut off at the coxa-trochanter joints. The wasp grasped the spider's spinnerets with her mandibles and, maintaining it ventral side upward, walked forward (Dankowicz 2015b).

PA: Montgomery County, Schwenksville; 19 August, 21 October 2015; D.J.G. Leffler. Hosts: Misumena vatia (Clerck) (Thomisidae) (Goldenrod Crab Spider), adult female; Anyphaena sp. (Anyphaenidae), penultimate male, both spiders with all legs but left foreleg amputated at coxa-trochanter joints. Both wasps transported the paralyzed spider, ventral side upward, grasping its spinnerets with the mandibles (D.J.G. Leffler, Schwenksville, PA, 2015 pers.comm.; WanderingMogwai 2015a, b).

VA: City of Williamsburg; 19 October 2013; LilWeezyAnna. Host: Hibana gracilis, $10.5 \mathrm{~mm}$ (wasp, $9 \mathrm{~mm}$ ), with all legs and pedipalps, except $3^{\text {rd }}$ left leg and left pedipalp amputated at coxa-trochanter joints. The wasp walked forward grasping the spider ventral side upward by its spinnerets with her mandibles (LilWeezyAnna 2013).

\section{Auplopus architectus architectus (Say) $\mathrm{x}$ Auplopus architectus metallicus (Banks) intergrade}

UT: Kane County, Coral Pink Sand Dunes State Park; 22 September 2015; K. Schneider. Host: Cheiracanthium sp., penultimate female, $6 \mathrm{~mm}$ (wasp, $9 \mathrm{~mm}$ ), with only 3 legs amputated at the coxa-trochanter joints. The wasp straddled the paralyzed spider, ventral side upward, grasped its spinnerets with her mandibles, and walked forward (Schneider 2015).

\section{Auplopus architectus metallicus (Banks)}

CA: Santa Cruz County, Santa Cruz; 21 August 2014; A. S. Macmillan. Host: Anyphaenidae, adult female. The wasp with prey was photographed after she cut off the remaining legs of her spider. She then grasped it by its spinnerets with her mandibles and, maintaining it ventral side upward, took flight (Macmillan 2014).

BC, CANADA: Cowichan Valley; 17 August 2013; K. Basu. Host: Clubiona lutescens Westring (Clubionidae) (Northern Yellow Sac-spider), adult female, $8 \mathrm{~mm}$ (wasp, $8 \mathrm{~mm}$ ). A series of photographs and a video show the wasp grasping the spider, 
with 6 of its 8 legs intact, by its spinnerets, ventral side upward (Fig. 10), walking forward, pausing and grooming the prey prior to amputating its remaining legs at the coxa-trochanter joints, attempting to cut off the right front leg, and redirecting her position for orientation. The hindlegs were cut off before the photographs were taken (Basu 2013; K. Basu, Shawnigan Lake, BC, Canada, 2014 pers. comm.).

\section{Auplopus caerulescens subcorticalis (Walsh)}

OK: Marshall County, Kingston, University of Oklahoma Biological Station, inside barn on wooden floor in open grassy area; October 2013; R.K. Walton. Host: Maevia sp. (Salticidae), immature, $6.6 \mathrm{~mm}$ (wasp, $6.5 \mathrm{~mm}$ ), with all legs amputated at coxa-trochanter joints. The wasp grasped the spider by its spinnerets with her mandibles and, holding it ventral side upward, walked forward (Walton 2013; R.K. Walton, Concord, MA, 2013 pers. comm.).

\section{Auplopus carbonarius (Scopoli)*}

ON, CANADA: Regional Municipality of Waterloo, Waterloo, 8 June 2012; N. Smith. The female returned to her nesting site and landed nearby, holding a moist mud pellet with her mandibles (Fig. 11; Smith 2012a; N. Smith, 2014 pers.comm.).

ON, CANADA: Regional Municipality of Waterloo, Waterloo; 22 July 2012; N. Smith. Host: Misumena vatia, adult female, with all legs amputated at the coxa-trochanter joints. The wasp walked forward on a leaf, grasping the spider ventral side upward by its spinnerets with her mandibles (Fig. 12). She abruptly flew from the leaf and disappeared from view (Smith 2012b; N. Smith, 2013, 2014 pers.comm.).

ON, CANADA: Regional Municipality of Waterloo, Waterloo; 26 July 2016, 1722 (EDT); N. Smith. Host: Cheiracanthium mildei, adult male. The wasp was 1.6 times longer than the paralyzed spider. A series of 3 images shows the spider being transported ventral side upward, its spinnerets being grasped by the wasp's mandibles. All 3 images show the spider's legs amputated at the coxa-trochanter joints, except for the left foreleg, right $3^{\text {rd }}$ leg, and both pedipalps. The $3^{\text {rd }}$ image shows the wasp attempting to cut off the spider's $3^{\text {rd }}$ right leg near its base (Smith 2016; N. Smith, 2016 pers. comm.).

Figure 10. Auplopus architectus metallicus female grasps a paralyzed Clubiona lutescens adult female, with 2 of 8 legs amputated at the coxatrochanter joints, ventral side upward, and, holding it by its spinnerets with her mandibles, walks forward. The wasp cut off the spider's remaining legs before reaching her mud

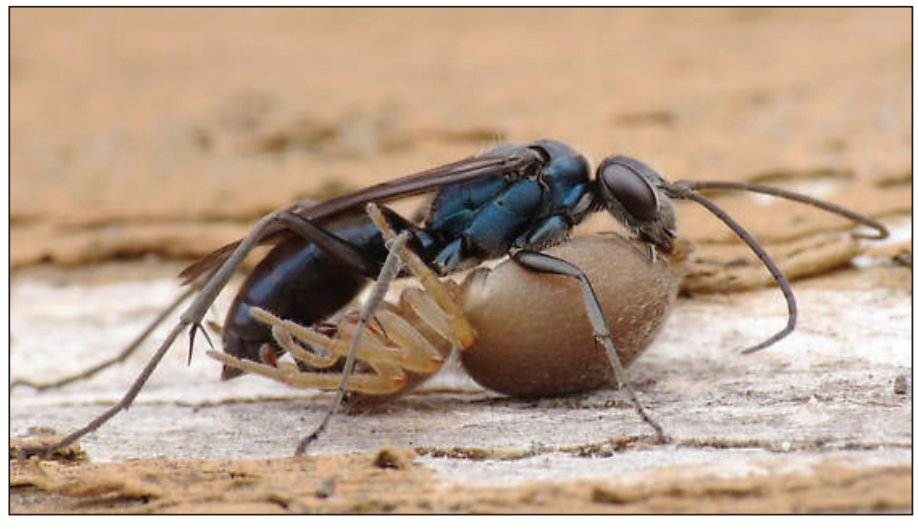
cell (K. Basu, 2014 pers. comm.) 
Figure 11. Auplopus carbonarius female holds a moist mud pellet with her mandibles (N. Smith, 2014 pers.comm.).

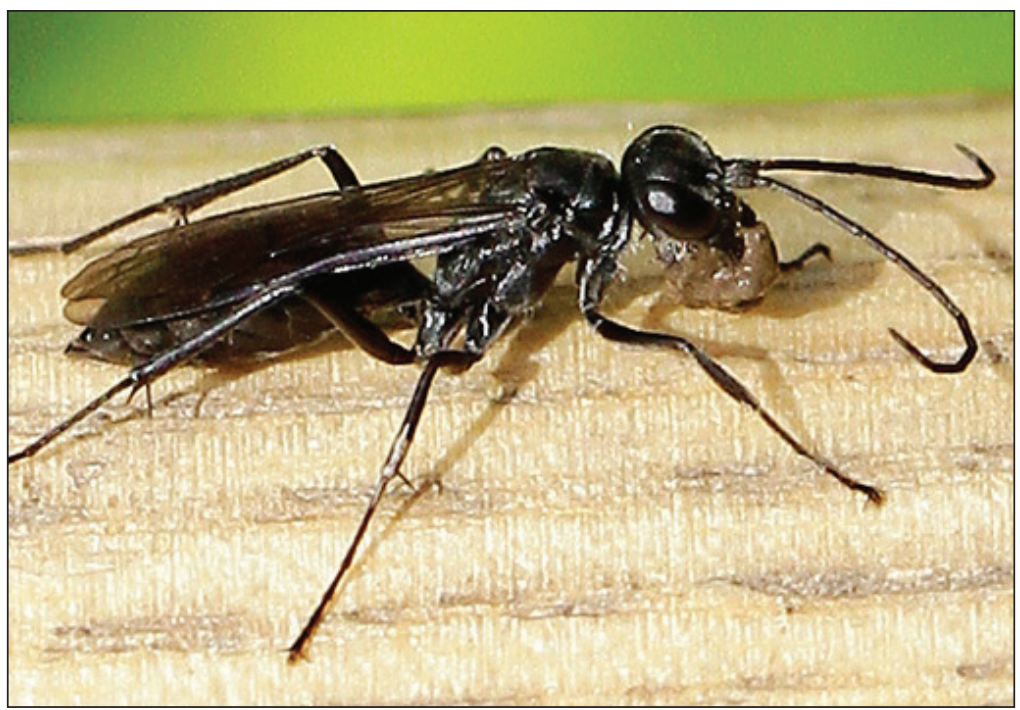

Figure 12. Auplopus carbonarius female walks forward on a leaf, grasping a paralyzed Misumena vatia adult female with all legs cut off at coxa-trochanter joints, ventral side upward, by its spinnerets with her mandibles (N. Smith, 2014 pers. comm.).

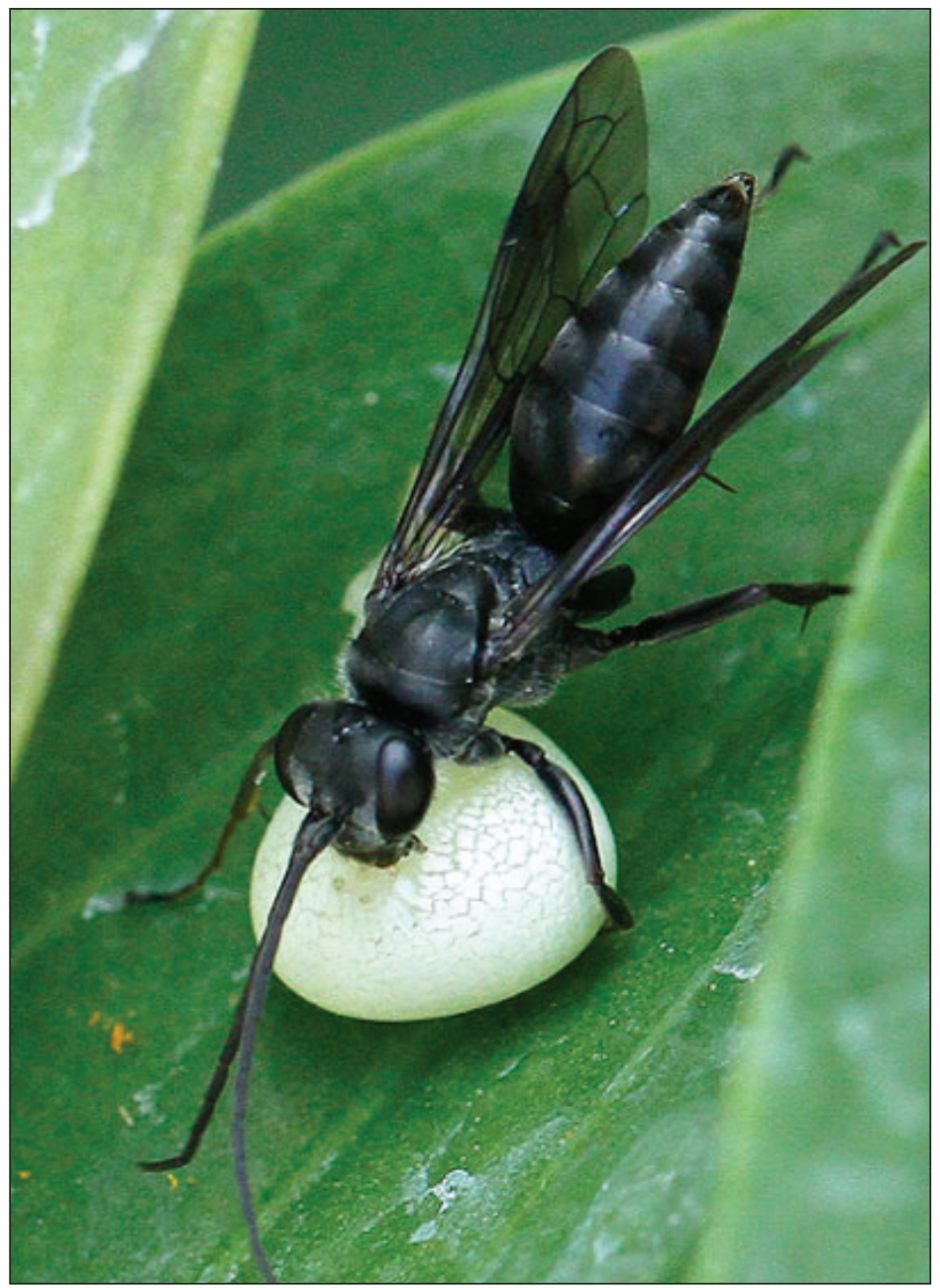


QC, CANADA: Brossard; 4 August 2007; A. Bateman. Host: ?Agroeca sp., subadult female, with all but left $2^{\text {nd }}$ leg cut off at the coxa-trochanter joints. The wasp walked forward, grasping the spider ventral side upward by its spinnerets with her mandibles. She made short hopping flights during which her wings were held almost vertically above her body and used continually. She eventually flew directly downward to the ground and disappeared in grasses near the base of a wall (Bateman 2007)

*A recent adventive species, $A$. carbonarius now inhabits New York, Michigan, Wisconsin, Washington, Ontario, Quebec, and probably other states and provinces in the US and Canada (Buck 2005, Kurczewski and Edwards 2012, Kurczewski and Kiernan 2015, Kurczewski and O'Brien 1991, Nolfo 1983, this study). Auplopus carbonarius is similar in size, color, host preferences, and nesting behavior to $A$. mellipes variitarsatus, often resulting in its misidentification in North America. Auplopus carbonarius females can be distinguished from A. mellipes variitarsatus females by the oval, flattened, bare, and shiny or polished pygidium $\left(6^{\text {th }}\right.$ abdominal tergite) without evident punctures and setae (Fig. 13); A. mellipes variitarsatus has a mat or dull pygidium with scattered punctures and setae (Fig. 14).

\section{Auplopus mellipes mellipes (Say)}

IL: Calhoun County, Two Rivers National Wildlife Refuge; 13 June 2010; G. Montgomery. Host: Clubiona sp. The wasp carried the spider forward on a leaf, ventral side upward, grasping its spinnerets with her mandibles (Montgomery 2010).

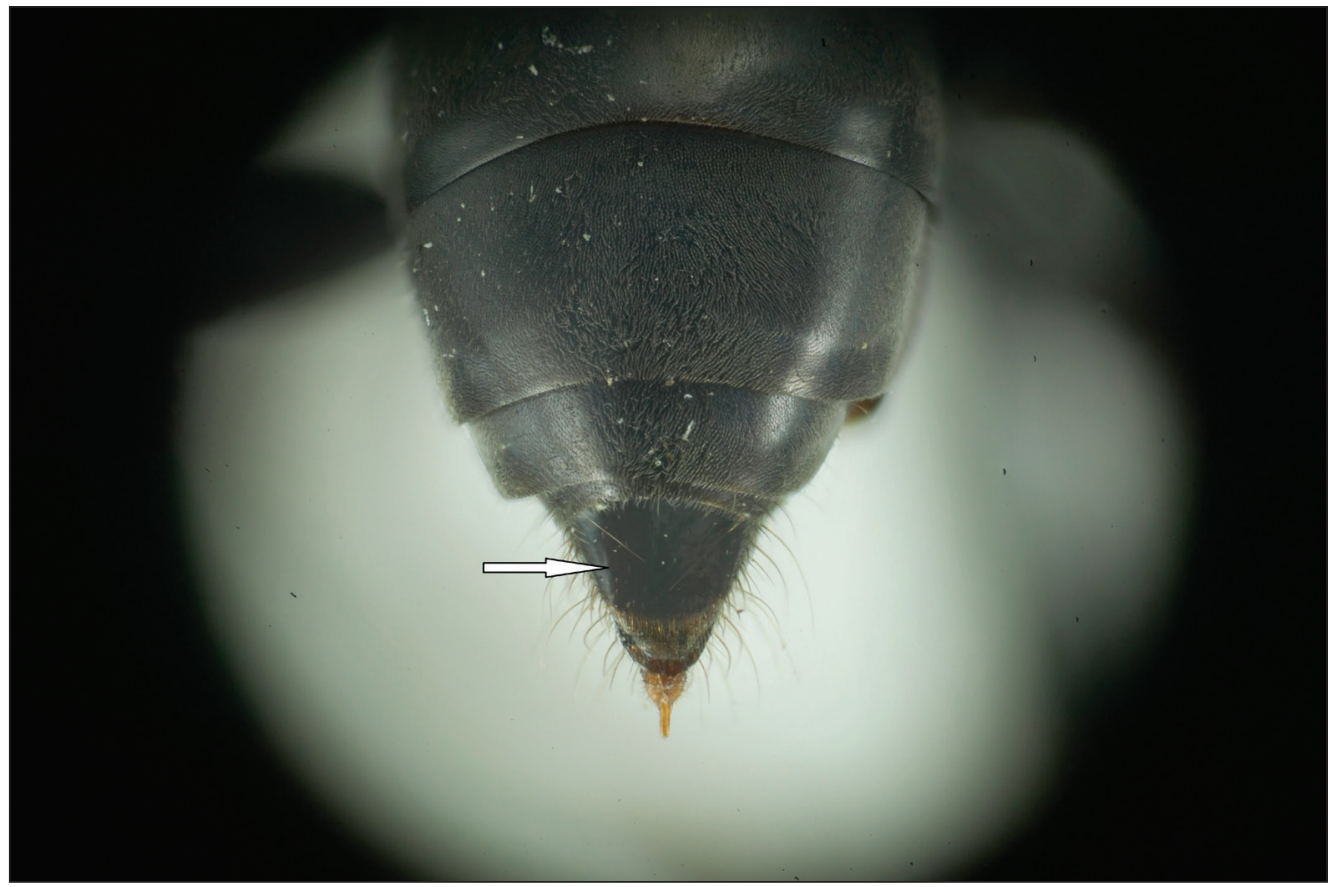

Figure 13. Oval, flattened, bare, shiny pygidium ( $6^{\text {th }}$ abdominal tergite) of Auplopus carbonarius (T. Yau, 2014 pers. comm.). 
TX: Travis County, Austin, University of Texas, Lady Bird Johnson Wildflower Center; 21 August 2010; V. Bugh. Host: Phidippus arizonensis (Peckham \& Peckham) (Salticidae) (Arizona Jumping Spider), adult female, with all legs except $1^{\text {st }}$ and $2^{\text {nd }}$ left legs, cut off at coxa-trochanter joints. The wasp carried the spider ventral side upward and abdomen forward, grasping its spinnerets with her mandibles (Bugh 2010).

\section{Auplopus mellipes variitarsatus (Dalla Torre)}

MA: Essex County, Salem; 8 October 2013; P. Cristophono. Host: Phidippus sp., possibly clarus Keyserling, subadult, $8 \mathrm{~mm}$ (wasp, $9 \mathrm{~mm}$ ), with all legs amputated at the coxa-trochanter joints. The wasp flew with her paralyzed spider from leaf to leaf. She held the spider, ventral side upward, grasping its spinnerets with her mandibles (Cristophono 2013).

MA: Hampshire County, Amherst; 19 August 2004; T. DiTerlizzi. Host: Clubiona sp., adult female, with all legs amputated at the coxa-trochanter joints. The wasp dragged the spider to a crack between bricks in a basement wall of a house. She held the spider ventral side upward, grasping its spinnerets with her mandibles (DiTerlizzi 2004).

MD: Prince George's County; 18 May 2015; J. Christopherson. Host: Cheiracanthium mildei, adult female, with all legs amputated at the coxa-trochanter joints. The wasp straddled the paralyzed spider, ventral side upward, and transported it forward, grasping its spinnerets with her mandibles (Christopherson 2015).

NJ: Passaic County, Clifton; 27 July 2014; H. Go. Host: Clubiona sp., adult female, with all legs amputated at the coxa-trochanter joints. The wasp flew in

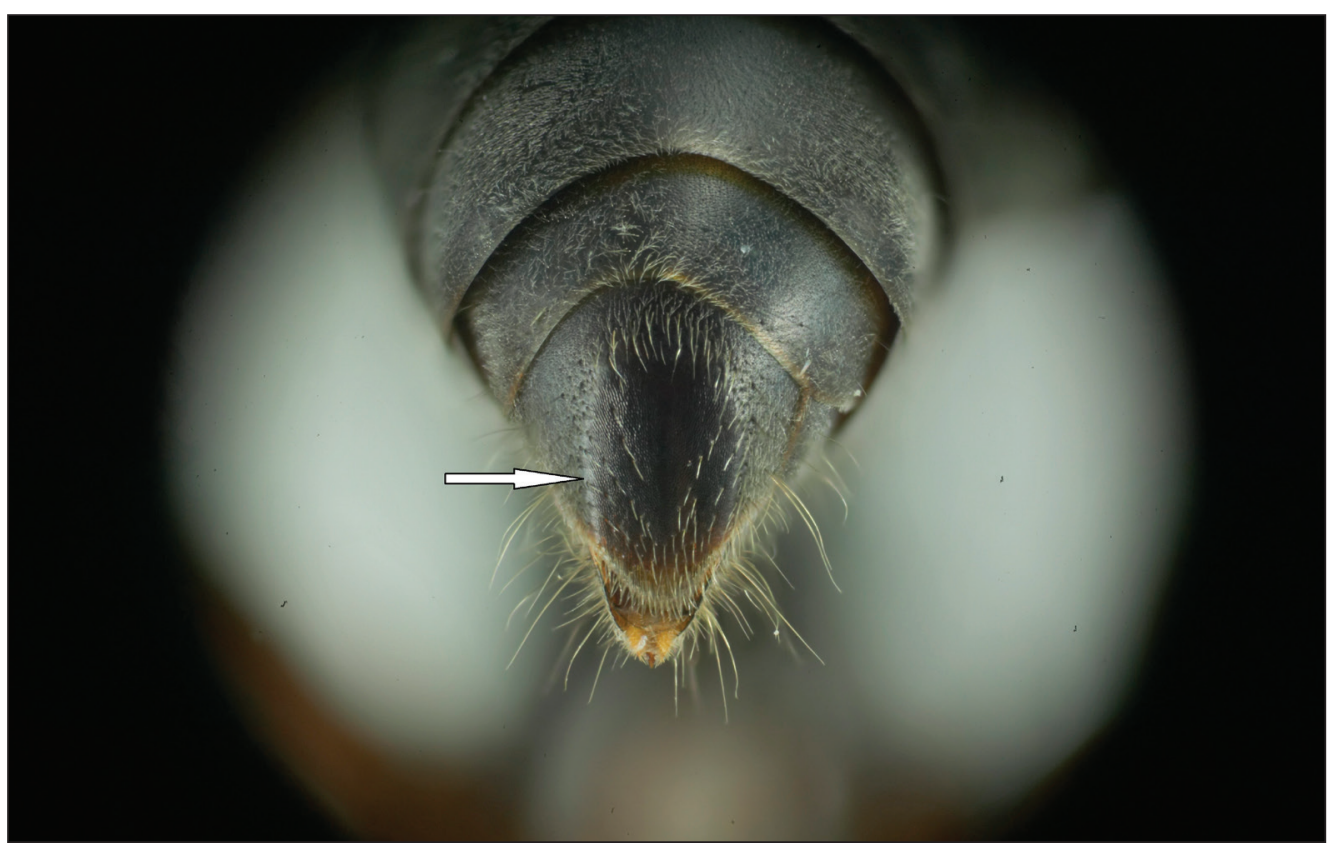

Figure 14. Matt, less-shiny pygidium with scattered punctures and setae of Auplopus mellipes (T. Yau, 2014 pers. comm.). 
holding the spider underneath and landed, retaining the spider in a ventral side upward position and grasping its spinnerets with her mandibles (Go 2014).

NY: Onondaga County, Syracuse, Onondaga Hill, back deck of house; 17-18 June 2015; FEK. Host: Platycryptus undatus, penultimate female, 9.5, 9 mm (wasp, $8.8 \mathrm{~mm}$ ); both spiders had all legs amputated at the coxa-trochanter joints (F.E. Kurczewski, 2015 pers. observ.).

PA: Delaware County, Norwood; 5 September 2013; M.L. Schmidt: Host: Cheiracanthium mildei, subadult female, $7.2 \mathrm{~mm}$ (wasp, $6.5 \mathrm{~mm}$ ). The wasp just finished amputating the left hindleg of her prey at the coxa-trochanter joint and fed on hemolymph at the point of amputation (M.L. Schmidt, Norwood, PA, 2013 pers. comm.).

PA: Montgomery County, Greater Philadelphia Area; 1 June 2009; G. V. Hart. Host: Cheiracanthium mildei, adult female, with all legs amputated at the coxatrochanter joints. The wasp flew onto an iron railing holding the paralyzed spider underneath, ventral side upward. She grasped the spider by its spinnerets with her mandibles (Hart 2009; G.V. Hart, Montgomery County, PA, 2015 pers. comm.).

VT: Locality unknown; 2 July 2004; C. Eiseman; Host: Cheiracanthium inclusum or $C$. mildei, adult or penultimate female, $9 \mathrm{~mm}$ (wasp, $9 \mathrm{~mm}$ ). The wasp transported the spider, which had all but its 2 front legs and pedipalps cut off at the coxa-trochanter joints, ventral side upward, grasping its spinnerets with her mandibles (Eiseman 2004; C. Eiseman, Pelham, MA, 2014 pers.comm.).

\section{Ageniella (Priophanes) arcuata (Banks)}

NJ: Camden County, Atco, on winged sumac leaf; 27 June 2014; Y. Alexander. Host: Oxyopes salticus Hentz (Oxyopidae) (Striped Lynx Spider), adult female, with all legs amputated at coxa-trochanter joints. The wasp held the paralyzed spider, ventral side upward, grasping its spinnerets with her mandibles and walked or made short flights forward (Alexander 2014).

\section{Ageniella (Ageniella) accepta (Cresson)** or Ageniella (Ageniella) conflicta Banks}

TX: Williamson County, Balcones Canyonlands National Wildlife Refuge, Gainer Tract, mixed grass prairie on calcareous soil; 2 September 2010; P.A. Lenhart. Host: Rabidosa punctulata (Hentz) (Lycosidae) (Dotted Wolf Spider), juvenile. This spider wasp-spider encounter was described under A. accepta by Kurczewski and Edwards (2012). However, a study of additional photos indicates the wasp species could be either $A$. accepta or the closely related A. conflicta. A series of 3 photos shows (1) the wasp straddling the spider dorsal side upward and face forward, grasping a chelicera with her mandibles, and walking forward on the ground; (2) the wasp feeding on the spider's right foreleg at the point of coxa-trochanter amputation; and (3) the paralyzed spider, with all legs missing beyond the coxae, lying dorsal side upward on the ground surface (Lenhart 2010; P.A. Lenhart, University of Kentucky, Lexington, KY, 2014 pers. comm.).

**See Waichert et al. (2011). 


\section{Ageniella (Ageniella) conflicta Banks}

MA: Franklin County, Orange, Orange Municipal Airport; 7 September 2009; E.R. Eaton. Host: ?Arctosa sp. (Lycosidae), juvenile, with all legs amputated at coxa-trochanter joints. The wasp walked forward on sandy soil, holding the spider dorsal side upward and face forward while grasping its chelicerae with her mandibles. She made no attempt to fly with the paralyzed spider (Eaton 2012a; E.R. Eaton, Colorado Springs, CO, 2013 pers. comm.).

\section{Subfamily POMPILINAE}

\section{Tribe Aporini}

\section{Aporus (Plectraporus) hirsutus (Banks)}

CA: Santa Barbara County, Surf Beach, Southern Coastal Dune habitat; 28 March 2015; A.J. Abela. Host: Aptostichus simus Chamberlin (Euctenizidae) (Southern Coastal Dune Trapdoor Spider), immature. The wasp examined the spider with her antennae and mouthparts after stinging it (Abela 2015a; A.J. Abela, 2015 pers.comm.).

CA: Santa Barbara County, Southern Coastal Dune Habitat; 17 June 2015; A.J. Abela. Host: Aptostichus simus, juvenile, $14.8 \mathrm{~mm}$ (wasp, $13 \mathrm{~mm}$ ). A series of photographs shows the wasp dragging the much heavier spider backwards, grasping the base of its left pedipalp or femur of $2^{\text {nd }}$ left leg with her mandibles (see Back Cover image; Abela 2015b; A.J. Abela, 2015 pers. comm.).

\section{Tribe Pompilini}

\section{Agenioideus (Agenioideus) humilis (Cresson)}

CA: San Luis Obispo County, Morro Bay State Park, Peninsula Marina; 24-26 August 2014, 0913-1049, 1603-1755 (PDT), 18-22 ${ }^{\circ} \mathrm{C}$; FEK. Host: Zygiella $x$-notata (Clerck) (Araneidae) (Silver-sided Sector Spider), penultimate female, 6.5, 6.5, $6.5 \mathrm{~mm}$; penultimate male, $6 \mathrm{~mm}$; immature, $5.5 \mathrm{~mm}$ (wasps, $8,8.5 \mathrm{~mm}$ ). Several wasps nested near the base of a steep sandy loam cliff and in soil-filled openings in a vertical retaining wall behind the marina. They captured subadult female and male and immature $Z$. $x$-notata by chasing the spiders from their webs onto vegetation and the ground (F.E. Kurczewski, 2014 pers. observ.).

CO: El Paso County, Colorado Springs, North Cheyenne Canon Park, elevation 2042 m, mixed conifer forest; 27 June 2015; E.R. Eaton. Host: Neoscona arabesca (Walckenaer) (Araneidae) (Arabesque Orbweaver), penultimate female, 6-7 $\mathrm{mm}$ (wasp, 7-8 $\mathrm{mm}$ ). The wasp transported the paralyzed spider down the rockwork of the exterior wall of an outbuilding in the park following a "zigzag" route. She grasped the base of the spider's $2^{\text {nd }}$ left leg with her mandibles and held it in a dorsal side upward or sideways position during the decent. She released the spider ventral side upward on the ground, examined it, groomed herself, and then walked 30 $\mathrm{cm}$ away to resume burrow excavation. She excavated in loose stony debris, using her forelegs alternately and rapidly (Eaton 2015; E.R. Eaton, 2015 pers. comm.). 
IA: Marion County, Pella; 22 August 2016; S.R. Johnson. Host: Neoscona crucifera (Lucas) (Spotted Orbweaver), adult female (wasp, $7 \mathrm{~mm}$ ). The wasp examined the paralyzed spider with her antennae and mouthparts as it laid dorsal side upward on the ground (Johnson 2016).

NY: Putnam County; 5 July 2013; E. Dankowicz. Host: Eustala anastera (Walckenaer) (Araneidae) (Humpbacked Orbweaver), adult female. The wasp pulled the spider backwards, dorsal side upward, grasping its right foreleg near the middle with her mandibles (Dankowicz 2013).

PA: Lebanon County, Annville; 27 August 2013; 1550-1600 (EDT); N. Elhardt. Host: Araneus pegnia (Walckenaer) (Araneidae) (Butterfly Orbweaver), adult female, $7.2 \mathrm{~mm}$ (wasp, $8.5 \mathrm{~mm}$ ). The wasp pulled her paralyzed spider across a porch floor, up a door frame, and onto the plastic siding of an outbuilding, grasping it dorsal side upward or on its side with her mandibles by the base of its $2^{\text {nd }}$ left leg (Fig. 15). During transport, $2 \mathrm{~m}$ above ground level, her prey became entangled in the web of a smaller spider, Hentziectypus sp. (Theridiidae), juvenile, and the wasp tried repeatedly for several minutes to unsuccessfully free it. Eventually, she abandoned the ensnared paralyzed araneid and began searching for another prey elsewhere. During prey transport, the female was trailed by a conspecific male that attempted to mate with her. She soon stalked another female of $A$. pegnia in its web. As the wasp approached to within $15 \mathrm{~cm}$ of the spider, the potential prey dropped from its web to the ground and ran and hid in vegetation to avoid capture. (N. Elhardt, 2013 pers. comm.).

WI: Outagamie County, Appleton; 1 August 2005; P. Hankey. Host: Araneus sp., penultimate male. The wasp dragged the paralyzed spider backwards on the substrate, dorsal side upward, grasping the base of its right foreleg with her mandibles (Hankey 2005).

Figure 15. Agenioideus humilis female drags a paralyzed Araneus pegnia adult female on its right side up a vertical surface, grasping it with her mandibles by the base of its $2^{\text {nd }}$ left leg $(\mathrm{N}$. Elhardt, 2013 pers. comm.).

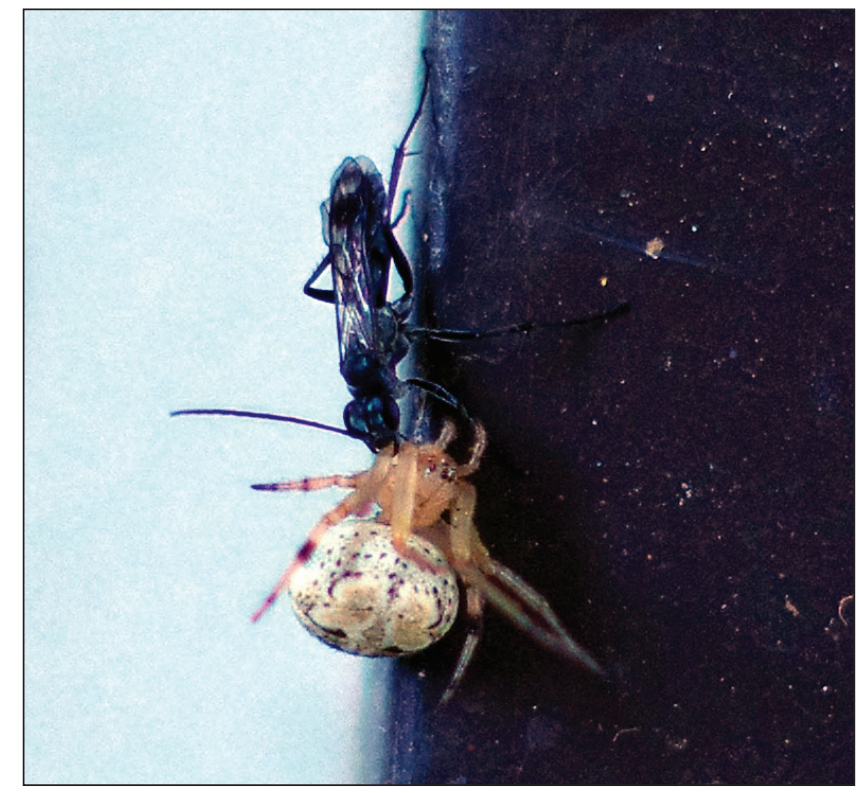




\section{Agenioideus (Gymnochares) birkmanni (Banks)}

GA: Clarke County, Athens, Sandy Creek Park, oak-hickory-loblolly pine woodland, open area on lake shore between parking lot and fishing pier; 22 August 2010; C.C. Champagne. Host: Platycryptus undatus, adult female, 9 mm (wasp, 6.5 $\mathrm{mm}$ ). The wasp dragged the much larger and heavier paralyzed spider backwards, vertically up the side wall of an enclosed picnic shelter, holding it dorsal side upward by the base of its left foreleg with her mandibles (Fig. 16; Champagne 2010; C.C. Champagne, Athens, GA, 2014 pers. comm.).

OK: Osage County, Sand Springs; 5 September 2009; Sam Houston. Host: Platycryptus undatus, adult male, $9 \mathrm{~mm}$ (wasp, $11 \mathrm{~mm}$ ). The wasp pulled the paralyzed spider backwards up a smooth, wooden vertical surface alternately holding it ventral side upward or on its left side while grasping its left foreleg midway from the end with her mandibles (Houston 2009).

Figure 16. Agenioideus birkmanni female drags a paralyzed Platycryptus undatus adult female backwards up a vertical wall, grasping it dorsal side upward by the base of its left foreleg with her mandibles (C.C. Champagne, 2014 pers. comm.).

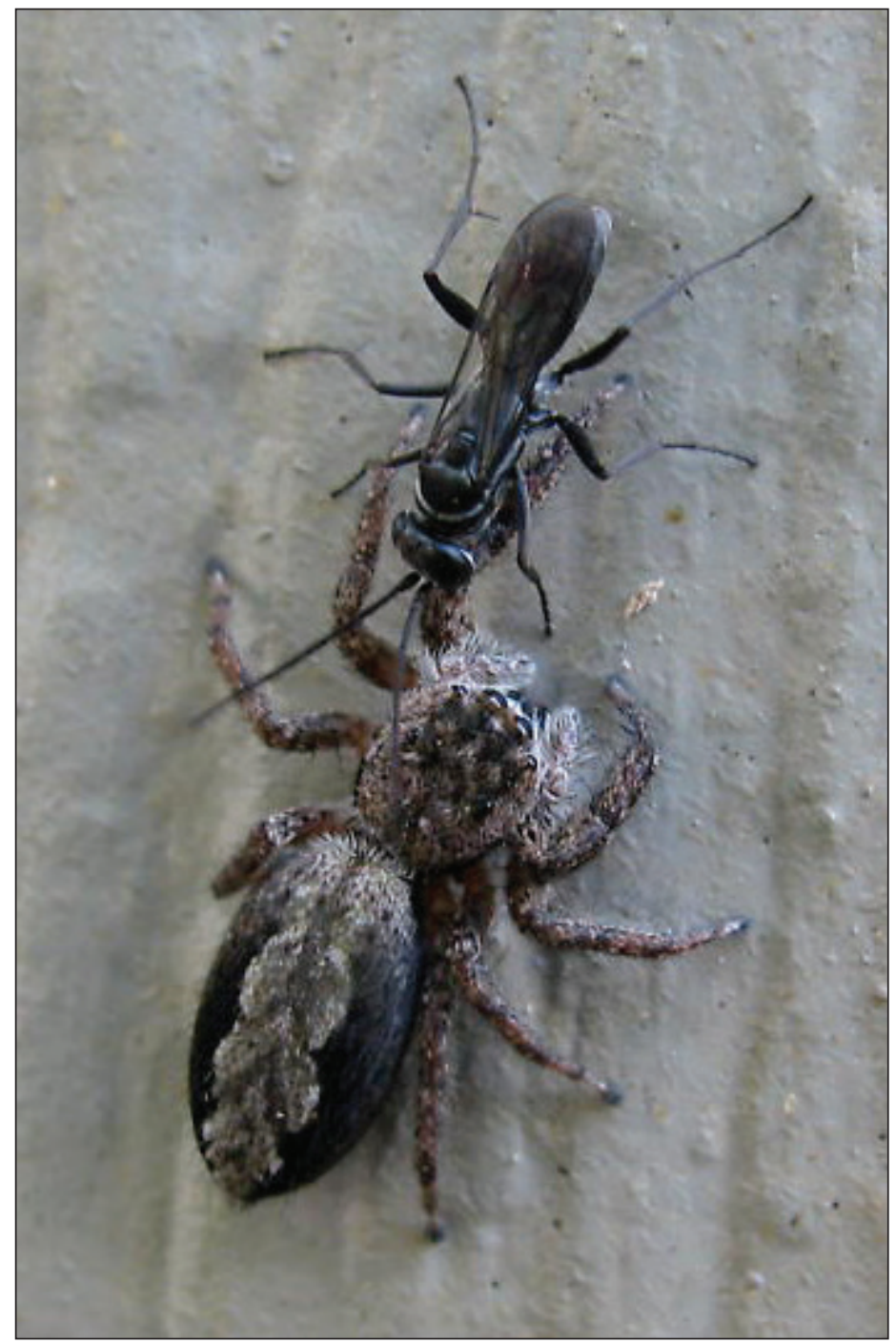


OK: Seminole County, Seminole; 30 June 2011; A. Goodman. Host: Platycryptus undatus, adult female. The wasp pulled the paralyzed spider backwards on a smooth horizontal surface, dorsal side upward, grasping the prey's left foreleg with her mandibles at or near the patella. Simultaneously, an unidentified crab spider (Thomisidae) pulled the paralyzed salticid in the opposite direction while holding onto its back end (Goodman 2011).

TX: Denton County, Lewisville; 4 September 2015; P. Murray. Host: Platycryptus undatus, adult female. The wasp grasped the paralyzed spider by its left foreleg with her mandibles and pulled it backwards across the smooth surface of an automobile (Murray 2015; P. Murray, Lewisville, TX, 2015 pers. comm.).

\section{Sericopompilus apicalis (Say)}

IA: Polk County, Sand Hill Prairie, Chichaqua Bottoms Greenbelt; 29 July 2011; J. VanDyk. Host: Phidippus clarus, adult female. The wasp positioned the spider atop a leaf, holding it in a ventral side upward position by its right pedipalp with her mandibles. Retaining this grasp, she walked backwards up a plant stem. At least 3 or 4 legs of the spider had been amputated beyond the coxae (VanDyk 2011; J. VanDyk, Iowa State University, Ames, IA, 2015 pers. comm).

\section{Sericopompilus neotropicalis (Cameron)}

CA: San Luis Obispo County, Montana de Oro State Park, Sandspit Parking Lot Northeast Trail; 20 August 2014, 1514 (PDT); FEK. Host: Phidippus clarus, adult male, $8 \mathrm{~mm}$ (wasp, $11.5 \mathrm{~mm}$ ). This species of pompilid, collected twice from Montana de Oro State Park in 2011 with Phidippus spp. prey, was misidentified as S. apicalis (Say) in Kurczewski and Edwards (2012) (F.E. Kurczewski, 2014 pers. observ.).

\section{Episyron biguttatus biguttatus (Fabricius)}

MD: Anne Arundel County, Tracys Landing; 9 July 2015; Eaglebeach. Host: Neoscona arabesca, adult female. A series of photographs shows the wasp (1) caching her paralyzed spider atop the upper leaves of a plant; (2) excavating her burrow using her forelegs, the excavation taking 25 minutes; and (3) moving the paralyzed spider, now lying dorsal side upward near the burrow entrance, prior to being pulled inside by the wasp (Eaglebeach 2015).

NH: Strafford County, Durham; 4 September 2008; J. Insinga. Host: Neoscona crucifera, adult female. The wasp grasped the spider by its $1^{\text {st }}$ or $2^{\text {nd }}$ right leg with her mandibles and pulled it, dorsal side upward, up the side of a stone bench (Insinga 2012).

NY: Cayuga County, Auburn; 2 October 2015; S. MacDerment. Host: Araneus saevus (L. Koch) (Fierce Orbweaver), adult female, $13.5 \mathrm{~mm}$ (wasp, 12.5). The wasp released the paralyzed spider on a porch, dorsal side upward, and temporarily flew away. She returned a minute or so later, grasped the spider by its $2 \mathrm{nd}$ left leg with her mandibles, and continued dragging it backwards across the porch (S. MacDerment, Syracuse, NY, 2015 pers. comm.).

OK: Cleveland County, Lexington, secondary cross timbers (various oak, elm, Celtis occidentalis L. [Hackberry], redbud), mowed lawn $9 \mathrm{~m}$ from edge of woods, 
red-earth clay; 27 July 2016; B.E. Reynolds. Host: Neoscona crucifera, penultimate male. A series of photos shows the wasp examining the paralyzed spider with her antennae and mouthparts (B.E. Reynolds, Lexington, OK, 2016 pers. comm.).

WI: Dane County, Middleton, Pheasant Branch Conservatory; 20 September 2011; T. Klein. Host: Argiope trifasciata (Fôrskal) (Araneidae) (Silver-banded Garden Spider), adult female. The paralyzed spider was cached above ground atop plant leaves during burrow excavation by the wasp (Klein 2011).

ON, CANADA: Regional Municipality of Durham, Pickering; 25 June 2006, 1758 (EDT); N. Smith. Host: Larinioides cornutus (Clerck) (Araneidae) (Furrow or Foliate Orbweaver), subadult female. The wasp grasped the spider with her mandibles by the base of its right foreleg and, with the spider on its left side, walked backwards on the ground (Fig. 17; Smith 2006; N. Smith, 2013 and 2014 pers. comm.).

ON, CANADA: Northumberland County, Roseneath; 25 June 2010, 1411-1414 (EDT); N. Smith. Host: Larinioides patagiatus (Clerck) (Ornamental Orbweaver), adult female. The spider and wasp were first seen "rolling around on a fieldstone porch". After stinging and paralyzing the spider, the wasp spent much time touching

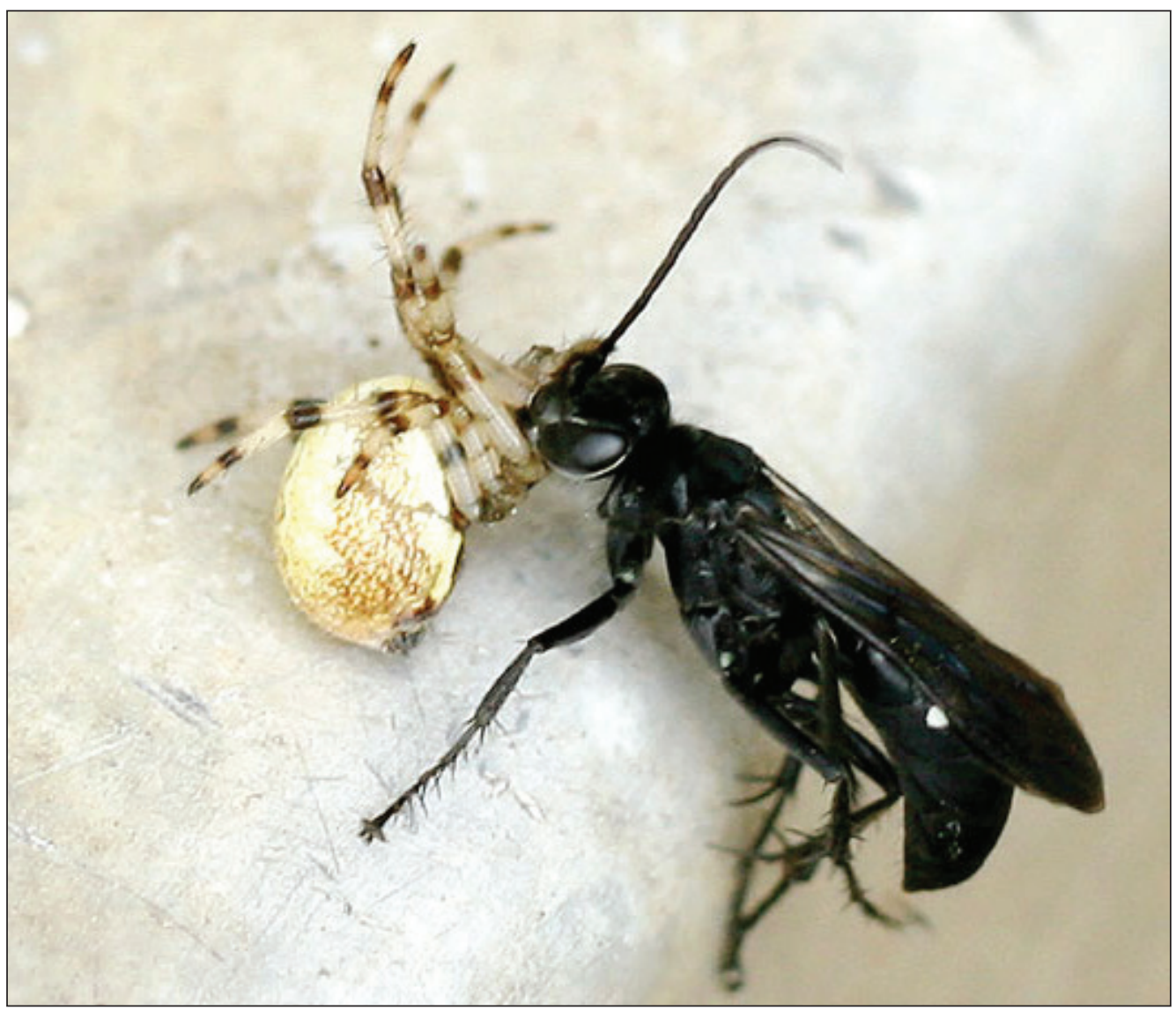

Figure 17. Episyron b. biguttatus female grasps a paralyzed Larinioides cornutus subadult female with her mandibles by the base of its right foreleg and, with the spider on its left side, walks backwards on the ground (N. Smith, 2014 pers. comm.). 
it with her antennae, mouthparts, and forelegs. She grasped it with her mandibles, dorsal side upward, and dragged it backwards by its left or right foreleg. The spider still contained web remnants after being captured (Smith 2010a; N. Smith, 2013 and 2014 pers. comm.).

\section{Episyron biguttatus californicus (Banks)}

CA: Los Angeles County, Ballona Wetlands Ecological Reserve Perimeter Trail; 3-4 September 2014, 1214-1641 (PDT), 26-27 ${ }^{\circ} \mathrm{C}$; FEK. Host: Neoscona oaxacensis (Keyserling) (Western Spotted Orbweaver), adult female, 10, 11.5, $12.5 \mathrm{~mm}$ (wasps, $12.5,13,13.5 \mathrm{~mm}$ ). The 3 wasps nested in a man-made, gravelly loam walking trail. Adult females of $N$. oaxacensis were abundant in orb-webs along the trail and throughout drier areas of the reserve (F.E. Kurczewski, 2014 pers. observ.).

CA: Orange County, Coto De Caza, Thomas F. Riley Wilderness Park; 1 August 2006; R. Hemberger. Host: Araneidae sp. The wasp dragged the spider backwards on the ground, grasping the base of its $2^{\text {nd }}$ right leg with her mandibles (Hemberger 2006).

CA: San Diego County; 30 September 2012; M. Wei. Host: Araneus gemmoides Chamberlin \& Ivie (Araneidae) (Jewel Orbweaver), adult female. A 3-part, 27-minute video shows the wasp transporting the paralyzed spider backwards across bare ground, rocks, stones, brush, and dried grasses. She released it on the ground, dorsal side upward, excavated a burrow in loamy soil with many small stones, eventually moved the spider nearer the opening, and released it dorsal side upward with its abdomen pointed toward the entrance before pulling it into the burrow by its spinnerets. During prey transport, the wasp grasped the base of the spider's $2^{\text {nd }}$ or, less often, $3^{\text {rd }}$ right leg with her mandibles, switching legs once or twice after releasing the prey on the ground and walking ahead in circles-probably a form of orientation/navigation. The spider was positioned obliquely dorsal side upward or upright and perpendicular to the body of the wasp during transport. The spider was released, dorsal side upward, several times and left unattended for 30 seconds or longer while the wasp reconnoitered ahead and for a much longer period when the wasp excavated her burrow. Lying unattended on the ground, the paralyzed spider attracted, at first, one and, then, several ants. During burrow excavation, the wasp broke the hard soil crust with her mandibles and then used her forelegs alternately to rapidly remove the loose soil backwards onto the ground surface. Her forelegs were fish-hooked medially to expose the largest number of digging comb-spines. She held her wings flat on the dorsum as she periodically removed stones from the excavation with her mandibles. Following an excavation that took longer than 20 minutes, the wasp dragged the spider closer to the entrance and released it $30 \mathrm{~cm}$ from the opening prior to entering with it (Wei 2012).

\section{Episyron conterminus cressoni (Dewitz)}

CA: Los Angeles County, Los Angeles, Dockweiler State Beach, behind the beach on bare sand with sparse vegetation; 3 September 2014, 1723 (PDT), $26{ }^{\circ} \mathrm{C}$; 
FEK. Host: Araneidae sp., adult male, 4.5 mm (wasp, 7 mm) (F.E. Kurczewski, 2014 pers. observ.).

FL: Collier County, Naples, The Naples Preserve; 5 August 2015; R.J. Speer. The spider wasp, $7 \mathrm{~mm}$ long, was captured and killed by a Green Lynx Spider, Peucetia viridans, on Coastalplain Goldenaster, Chrysopsis scabrella Torrey \& A. Gray (Asteraceae) (Speer 2015).

\section{Episyron quinquenotatus hurdi Evans}

CA: Los Angeles County, Los Angeles, Dockweiler State Beach, behind the beach on bare sand with sparse vegetation; 3 September 2014; 1748-1751 (PDT), $26{ }^{\circ} \mathrm{C}$; FEK. Host: Araneidae sp., adult female, $7 \mathrm{~mm}$ (wasp, $10 \mathrm{~mm}$ ) (F.E. Kurczewski, 2014 pers. observ.).

CA: San Diego County; 4 July 2013; M. Wei. Host: Araneus gemmoides, adult female. A 29-second video shows the wasp grasping the $1^{\text {st }}$ or $2^{\text {nd }}$ left leg of the spider with her mandibles after examining it with her antennae and mouthparts, and dragging it rapidly backwards across a concrete sidewalk and over a step (Wei 2013).

CA: San Luis Obispo County, Los Osos, El Moro Elfin Forest, relict sand dune; 27 August 2014, 1629 (PDT); FEK. Host: Metepeira spinipes F.O. Pickard-Cambridge (Araneidae) (Communal Tent Orbweaver), adult female, $7 \mathrm{~mm}$ (wasp, 8.5 $\mathrm{mm}$ ). The wasp nested in a bare sand opening surrounded by coastal dune scrub vegetation. She cached her paralyzed spider on California Sagebrush [Asteraceae: Artemisia californica (Lessing)] during burrow excavation (F.E. Kurczewski, 2014 pers. observ.).

CA: San Luis Obispo County, Montana de Oro State Park, Sandspit Parking Lot Northeast Trail; 17, 20, 24 August 2014, 1118-1648 (PDT), 22-26 ${ }^{\circ} \mathrm{C}$; FEK and KEK. Host: Araneus montereyensis (Archer), adult female, 5.5, $5.5 \mathrm{~mm}$ (wasps, $8.5,9 \mathrm{~mm}$ ). Five females captured host spiders but never finished excavating a burrow. All 5 wasps abandoned their excavations after 16-27 minutes of digging, perhaps not receiving appropriate soil humidity feedback related to the very dry soil conditions, the result of extreme drought in the region (F.E. Kurczewski and K.E. Kurczewski, 2014 pers. observ.).

CA: San Luis Obispo County, Morro Bay State Park, Marina Peninsula Trail; 26-27 August 2014, 1105-1316 (PDT), 18-22 ${ }^{\circ} \mathrm{C}$; FEK. Host: Zygiella $x$-notata, adult female, 7, 7.5, 8, $9 \mathrm{~mm}$ (wasps, 9, 8.5, 10.5, $11 \mathrm{~mm}$ ). Four wasps nested in bare, loose sand several meters from a compacted-soil walking trail. Their nestingbehavior components were similar to those reported for the nominate subspecies, E. q. quinquenotatus (Say) (Kurczewski 2001). The 4 nest entrances were 7.5, 10, 11 , and $11 \mathrm{~mm}$ in diameter, respectively, and fronted by a broadly crescent-shaped tumulus. The host spider species was abundant in webs in shrubs along the Peninsula Trail and in low-growth bushes just off the trail. The spiders sometimes remained in the hub of their orb web or, more often, hid beneath vegetation at the end of a signal thread. One E. quinquenotatus female attacked one such hidden female of $Z$. $x$-notata, which dropped quickly to the ground and ran across the sand into the waiting mouth of a lizard nearby (F.E. Kurczewski, 2014 pers. observ.). 


\section{Episyron quinquenotatus hurdi Evans x Episyron quinquenotatus quinquenota- tus (Say) intergrade}

UT: Davis County, Antelope Island, near the Visitor Center; 8 August 2010; D. Brady. Host: Neoscona oaxacensis, penultimate male. (Adult and penultimate males of this spider species were numerous on the island near the Visitor Center). The wasp grasped the paralyzed spider by the base of its $4^{\text {th }}$ right leg with her mandibles and held it in an almost upright perpendicular position during prey transport. When alarmed, she raised her wings to greater than a $45^{\circ}$ angle. She excavated her burrow in sand (Brady 2010).

\section{Episyron ?quinquenotatus quinquenotatus (Say)}

SK, CANADA: Meadow Lake region, 1600 section, remote farming area with Populus (poplar) and Picea (spruce) trees; 19 July 2010; S. Penner. Host: Araneus marmoreus Clerck (Marbled Orbweaver), adult female. The wasp grasped the paralyzed spider by the base of its right foreleg with her mandibles and, maintaining it dorsal side upward, pulled it backwards across a dirt road (Penner 2010).

\section{Poecilopompilus algidus algidus (Smith)}

FL: Duval County, Jacksonville; 15 August 2015, 1400 (EDT); C. Sheppard. Host: Neoscona crucifera, adult or penultimate female. The wasp flew around the outside of a house sunroom window and eventually chased a spider from its orb web. The spider dropped onto a patio behind the house whereupon it was stung several times in its cephalothorax by the wasp. The spider extruded silk from its spinnerets, presumably with each wasp sting. After the spider acquiesced, the wasp examined it with her antennae and even walked over it (C. Sheppard, Jacksonville, FL, 2015 pers. comm.).

TX: Harris County, Katy; 20 July 2013; D.R. Riley. Host: Eriophora ravilla (C.L. Koch) (Araneidae) (Tropical Orbweaver Spider), adult female, $16 \mathrm{~mm}$ (wasp, $20 \mathrm{~mm}$ ). The wasp pulled the spider backwards up a plant stem, grasping it by a hindleg with her mandibles. The paralyzed orb-weaver was cached atop a leaf, dorsal side upward, $15 \mathrm{~cm}$ above ground level (Fig. 18), after which the wasp flew down to the ground and began burrow excavation. The wasp's wings were raised at a $45^{\circ}$ or higher angle when backing from her burrow with sand or during periodic examination of the cached spider. After many minutes, the wasp retrieved the spider from its cache site, and, with it, flew to the ground. She then dragged it backwards on the ground toward the excavation, grasping it with her mandibles by the base of its $2^{\text {nd }}$ or $3^{\text {rd }}$ left leg (Riley 2013; D.R. Riley, Katy, TX, 2013 pers. comm.).

\section{Poecilopompilus algidus coquilletti (Provancher)}

UT: Uintah County, Dinosaur National Monument (western entrance), near Vernal; 17 September 2013; Sipolandis. Host: Argiope trifasciata, adult female. The wasp dragged the spider to the edge of a sidewalk, released it dorsal side upward, circled it, and flew away (Sipolandis 2013). 


\section{Poecilopompilus interruptus interruptus (Say)}

LA: Caddo Parish, 9.6 km E of Vivian, Royal Hills Farm; 25 July 2014, 1824 (CDT); R.M. Tyler Jr. Host: Neoscona crucifera, penultimate male. The wasp cached her paralyzed spider, dorsal side upward, on a broad leaf and repeatedly circled it (Fig. 19; Tyler 2014; R.M. Tyler Jr., Royal Hills Farm, Caddo Parish, LA, 2014 pers. comm.).

OK: Cleveland County, Lexington Wildlife Management Area, hard-packed sandy trail through crosstimbers habitat near Lake Dahlgren; 21 September 2015; B.E. Reynolds. Host: Neoscona crucifera, adult female. The wasp dragged the paralyzed spider backwards on the trail, grasping the base of its $3^{\text {rd }}$ or $4^{\text {th }}$ left leg with her mandibles (Back Cover). She released the spider on its right side between bursts of prey transport (Reynolds 2015a; B.E. Reynolds, 2015 pers. comm.).

Figure 18. Paralyzed Eriophora ravilla adult female cached dorsal side upward atop a leaf by a Poecilopompilus a. algi$d u s$, which examines it with her antennae (D.R. Riley, 2013 pers. comm.).

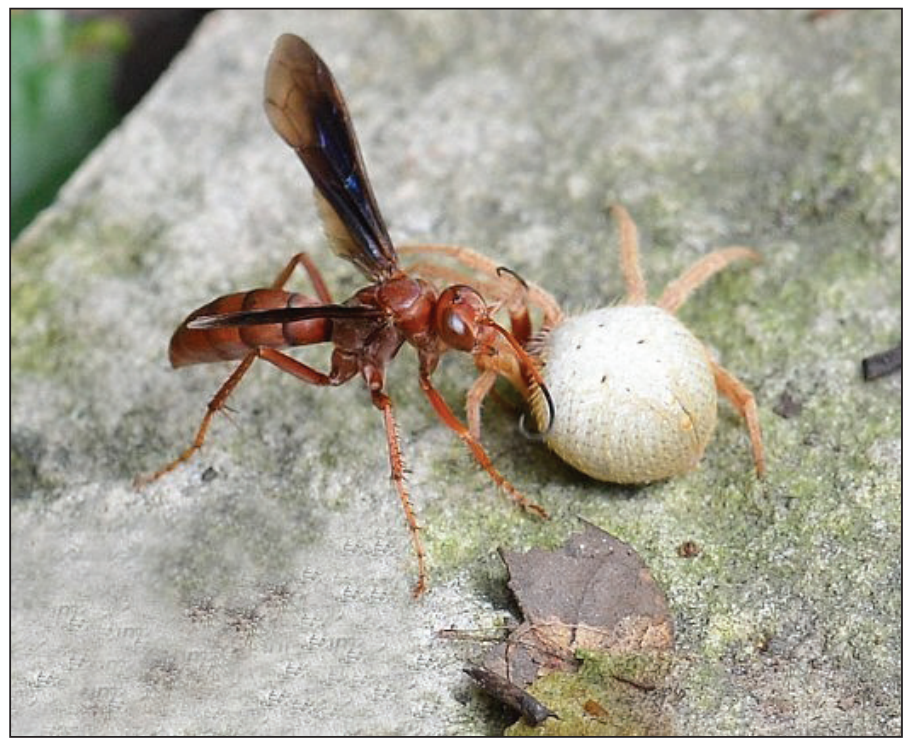

Figure 19. Paralyzed Neoscona crucifera penultimate male cached dorsal side upward atop a leaf while a Poecilopompilus $i$. interruptus female examines it (R.M. Tyler Jr., 2014 pers. comm.).

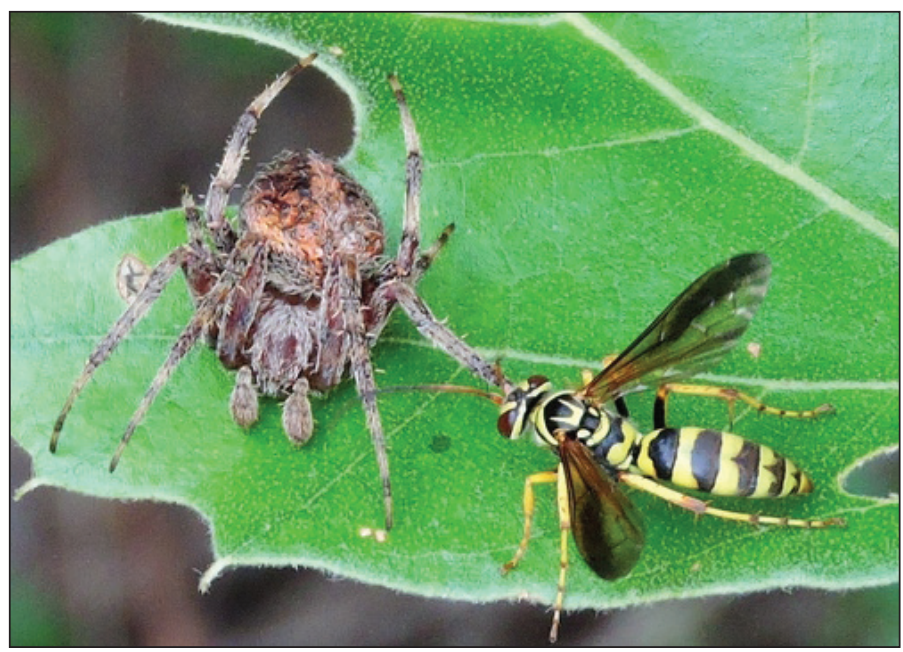


TX: Liberty County, Dayton; 4 June 2012; C. Micallef. Host: Eustala anastera, adult female. The wasp placed the paralyzed spider on its right side on sandy soil among large dried fallen leaves. She raised her wings at an angle higher than $45^{\circ}$ as she examined her prey with her antennae and mouthparts (Micallef 2012).

TX: Travis County, Austin, University of Texas, Lady Bird Johnson Wildflower Center; 21 August 2010; V. Bugh. Host: Neoscona crucifera, subadult female. The wasp dragged the spider backwards on the ground, grasping the base of its $2 \mathrm{nd}$ left leg with her mandibles. Her wings were raised at a $65-75^{\circ}$ angle above her dorsum as she released the spider on the ground surface and examined it (Bugh 2010).

\section{Tachypompilus ferrugineus annexus (Banks)}

TX: Blanco County, Big Mountain Trail, Round Mountain; 24 June 2013; R. Arvesen. Host: Rabidosa rabida, adult female. The wasp dragged the paralyzed spider backwards over rough ground, holding it dorsal side upward and grasping its left pedipalp with her mandibles. She pulled the spider up the side of a house, apparently retaining the same grasp for $\sim 60 \mathrm{~cm}$, then back down to the ground. The wasp interrupted transport several times as she released her prey on the ground and examined it (see Back Cover image; Arvesen 2013; R. Arvesen, Big Mountain Trail, Round Mountain, TX, 2014 pers. comm.).

TX: Tarrant County, Fort Worth, Arcadia Trail Park; 7 August 2013; J. L. Sikora. Host: Hogna antelucana, adult or subadult female, $18.5 \mathrm{~mm}$ (wasp, $18 \mathrm{~mm}$ ). The spider was dragged backwards through grasses, dorsal side upward, across and up a gravelly trail, and through grasses again by the wasp, which maintained her grasp of its left pedipalp with her mandibles (Taogirl [J.L. Sikora] 2013).

TX: Tarrant County, Fort Worth, Arcadia Trail Park; 21 June 2014; Naturenut. Host: Hogna antelucana, adult or subadult female. The wasp dragged the spider backwards on the ground, dorsal side upward, grasping a pedipalp with her mandibles (Naturenut 2014).

TX: Travis County, Austin, Hornsby Bend Wastewater Facility and Wildlife Areas; 30 July 2014; E. Isley, G. Lasley (separate accounts). Host: Rabidosa rabida, adult or subadult female. The wasp grasped the spider's right pedipalp with her mandibles and, maintaining it dorsal side upward, dragged it backwards on the ground (Isley 2014, Lasley 2014).

\section{Tachypompilus ferrugineus ferrugineus (Say)}

AR: Johnson County, Hagarville; 19 July 2015; Mayfly 1963. Host: Tigrosa helluo. The wasp pulled the paralyzed spider backwards up a vertical surface, grasping its pedipalp with her mandibles (Mayfly 1963 2015).

AR: Phillips County, Lexa; 30 August 2009; M.R. Corder. Host: Rabidosa rabida, adult female. The wasp dragged the spider backwards across a driveway, dorsal side upward, grasping a pedipalp with her mandibles and pausing frequently to examine it with her antennae (Corder 2009; M.R. Corder, Lexa, AR, 2013 pers. comm.).

CO: Jefferson County, Colorado Front Range, Red Rocks Park just east of the Trading Post; 1 July 2010, 1056-1058 (MDT); S.L. White. Host: Hogna 
carolinensis, penultimate male. A series of photographs shows the wasp examining the spider with her antennae and mouthparts, then leaving the paralyzed prey lying on the ground, ventral side upward or on its side, followed by a fight with a conspecific female over possession of the prey. The 2 wasps tumbled on the ground while trying to sting and bite each other with their mandibles. After several minutes, the victor eventually dragged the spider away, backwards on the ground, grasping the spider's pedipalp with her mandibles (White 2010; S.L. White, Denver, CO, 2014 pers. comm.).

FL: Pinellas County, Fort De Soto Park; 18 July 2015; J. Williamson. Host: Heteropoda venatoria L. (Sparassidae) (Domestic or Pantropical Huntsman Spider), immature female, $20 \mathrm{~mm}$ (wasp, $18.5 \mathrm{~mm}$ ). The wasp was observed dragging the paralyzed spider backwards, grasping a pedipalp with her mandibles (J. Williamson, Tierra Verde, FL, 2015 pers. comm.).

GA: Oglethorp County, Wolfskin District, 16 km SE Athens; 4 August 2008 (at dusk); W. Hughes. Erratum to Kurczewski and Edwards (2012). Host: Rabidosa punctulata, adult male, $15 \mathrm{~mm}$ (wasp, $17 \mathrm{~mm}$ ). (The spider was initially misidentified as a subadult Rabidosa rabida in Kurczewski and Edwards [2012] but an examination of additional photographs enabled us to change this identification). The wasp dragged the spider backwards, ventral side upward, grasping a pedipalp with her mandibles (Hughes 2008; W. Hughes, Wolfskin District, GA, 2012 pers. comm.).

KS: Gray County; 30 August 2006; Drakken. Erratum to Kurczewski and Edwards (2012). Host: Hogna carolinensis, adult or subadult female. (This spider was initially misidentified as ?Geolycosa sp. in Kurczewski and Edwards [2012]). The wasp pulled the paralyzed spider up the side of a house, dorsal side upward, grasping a pedipalp with her mandibles (Drakken 2006).

MD: Cecil County, Elkton; 14 July 2015; S. Schade. Host: Tigrosa helluo, adult female. The body length of the wasp was 0.9 times that of the spider. The wasp grasped the paralyzed spider by its right pedipalp, dorsal side upward, and pulled it backwards up a vertical surface (Schade 2015).

MO: Andrew County, Savannah; 17 July 2011, 22 July, 7 August 2015; S. Cox. Host: Tigrosa grandis, adult and subadult female; adult male (3 records), 20-25 $\mathrm{mm}$. The $1^{\text {st }}$ wasp dragged the smallest paralyzed subadult female spider rapidly backwards across a concrete porch floor, grasping its left pedipalp with her mandibles while keeping her wings flat on the dorsum. Every 1.5-1.8 m she released the spider, dorsal side upward, and reconnoitered ahead by walking. She repeatedly entered openings and crevices in a concrete wall behind the front steps. Finally, settling on a crack $15 \mathrm{~cm}$ above the porch floor, she pulled the spider inside until it disappeared from view. The distance from where she stung the spider to where she entered the crack in the wall was $6 \mathrm{~m}$. The $2^{\text {nd }}$ wasp dragged the largest and heaviest adult female spider backwards on the ground more slowly and haltingly than in the first observation, grasping its left pedipalp with her mandibles. The $3^{\text {rd }} T$. $f$. ferrugineus female reached a different outcome with her adult male spider. This paralyzed spider was stolen by marauding small black ants after the wasp released 
it on the concrete porch floor and walked ahead to reconnoiter. (S. Cox, Missouri Department of Conservation, St. Joseph, MO, 2015 pers. comm.).

NC: Wake County, William B. Umstead State Park, 12 km NW Raleigh; 24 July 2013; P.A. Scharf. Host: Dolomedes scriptus Hentz (dark morph) (Striped Fishing Spider), adult female (gravid), $21 \mathrm{~mm}$ (wasp, $19 \mathrm{~mm}$ ). The spider was dragged slowly and haltingly across a level concrete balcony, dorsal side upward, being grasped with the wasp's mandibles by its right pedipalp (Fig. 20). The spider's left foreleg had been amputated at the coxa-trochanter joint. There was a small creek and wetlands nearby from which the spider might have traveled to its demise (Scharf 2013; P.A. Scharf, Macon, NC, 2013 pers. comm.).

PA: Lebanon County, Annville; 31 August 2012, 1400 (EDT); N. Elhardt. Host: Tigrosa helluo, subadult female, $17.5 \mathrm{~mm}$ (wasp, $17 \mathrm{~mm}$ ). The wasp dragged the spider across a porch floor and through a gap between the cellar door and frame, grasping it with her mandibles by a left or right pedipalp or base of right foreleg, and holding it dorsal side upward. Prey transport was interrupted by periodic release and inspection of the spider, the wasp using her antennae and mouthparts. The wasp's nest was located between the frame and inner wall of the building (Elhardt 2012; N. Elhardt, 2013 pers. comm.).

TN: Sumner County, Hendersonville; 13 July 2016, 1008 (CDT); Martin-Hall. Host: Dolomedes tenebrosus, adult or subadult female, $20 \mathrm{~mm}$ (wasp, $18 \mathrm{~mm}$ ). The wasp grasped the paralyzed spider by a pedipalp with her mandibles, dorsal side upward, and dragged it backwards on the ground (Martin-Hall 2016).

TX: San Augustine County, Sabine National Forest; 4 July 2015, 1244 (CDT); Dandybiologist. Host: Dolomedes albineus, juvenile. The wasp walked nearly upside down beneath a wooden structure, grasping the paralyzed spider by its left pedipalp with her mandibles (Dandybiologist 2015).

VA: Rockingham County, Harrisonburg; 4 July 2012; G.K. Gerber. Host: Schizocosa avida (Walckenaer) (Lance Wolf Spider), adult female, $15.8 \mathrm{~mm}$ (wasp,

Figure 20. Tachypompilus f. ferrugineus female drags a paralyzed Dolomedes scriptus adult female backwards across a concrete balcony, grasping its right pedipalp with her mandibles (P.A. Scharf, 2013 pers. comm.).

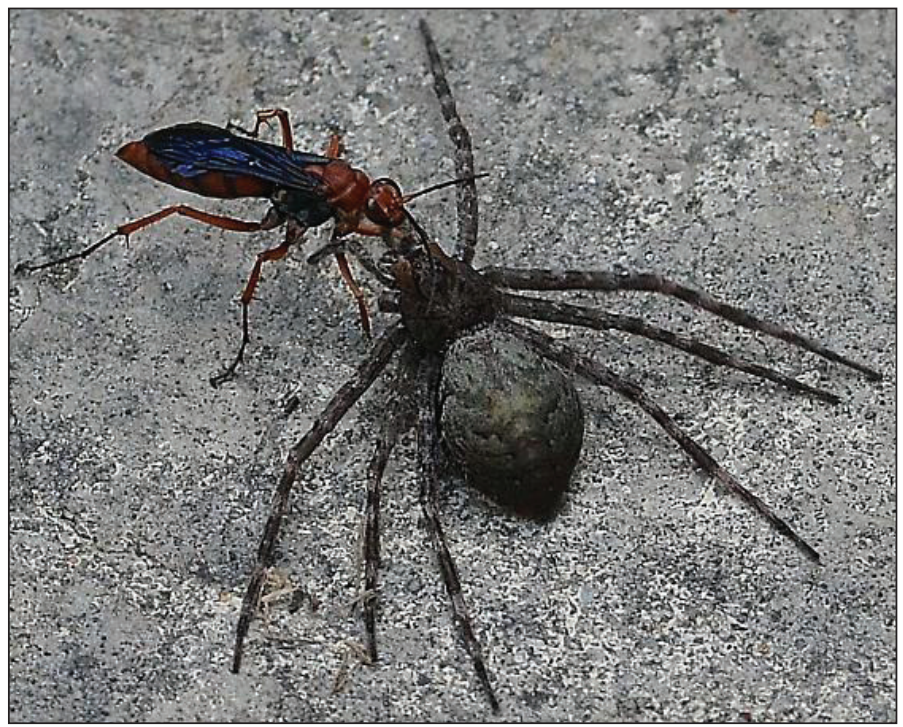


$17 \mathrm{~mm}$ ). The wasp grasped the right pedipalp of the spider with her mandibles and pulled it backwards, dorsal side upward, across a brick and concrete patio, releasing it periodically to examine it (Gerber 2012).

WV: Greenbrier County, Ronceverte; 4 September 2015, 1810-1845 (EDT); S.E. Ginsburg. Host: Tigrosa helluo, adult female, $17.5 \mathrm{~mm}$ (wasp, $20.8 \mathrm{~mm}$ ). The wasp grasped the paralyzed spider by its right pedipalp and attempted to scale a 3-m-high brick face of a house in order to reach a soffit with openings beneath the roof. She walked backwards up the vertical surface, got as high as the top of a window, but, then, holding the spider, fell back to the ground. The wasp tried repeatedly to pull the spider up the brick face, resting occasionally, but did not reach her destination (S.E. Ginsburg, Ronceverte, WV, 2015 pers. comm.).

ON, CANADA: Pelee Island; 23 August 2014; J.S. Griffin. Host: Dolomedes tenebrosus, adult female. The wasp dragged the paralyzed spider, dorsal side upward, across a compacted gravelly trail and into adjacent grasses, grasping its left pedipalp with her mandibles (Fig. 21; Griffin 2014; J.S. Griffin, Kingsville, ON, Canada, 2015 pers. comm.).

A re-examination of 6 host spiders of $T$. f. ferrugineus from a previous study (Kurczewski and Edwards 2012; BugGuide 64042, 64574, 239566, 300672, 306200 , 458075) identified simply as Hogna sp. produced the following revised identifications: Schizocosa sp, cf. Tigrosa helluo, T. helluo, T. grandis, T. helluo, and Hogna ?lenta (Hentz), respectively (L.L. Paxson, 2016 pers. comm.).

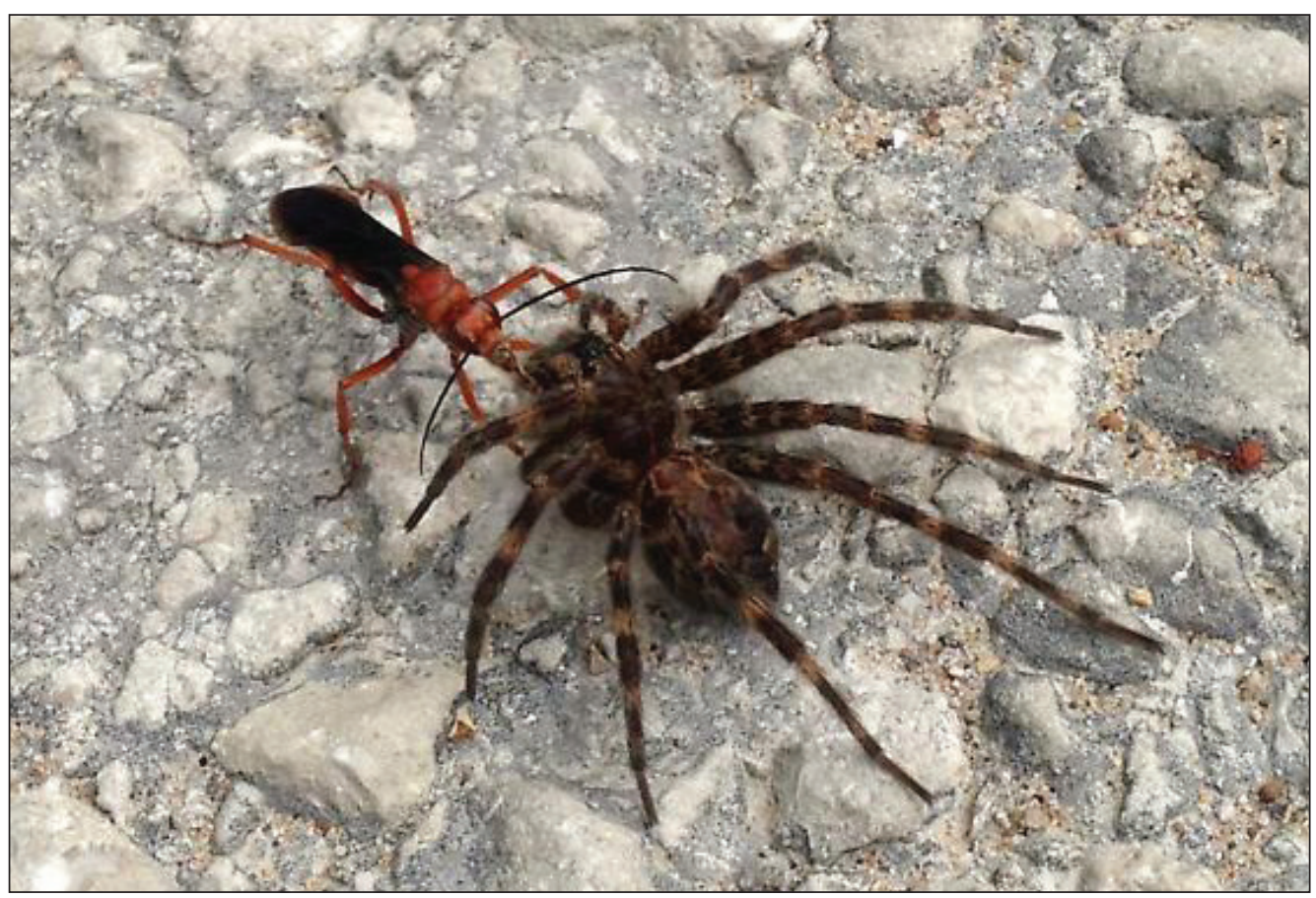

Figure 21. Tachypompilus $f$. ferrugineus female drags a paralyzed Dolomedes tenebrosus adult female backwards across a trail, grasping its left pedipalp with her mandibles (J.S. Griffin, 2015 pers. comm.) 


\section{Tachypompilus unicolor unicolor (Banks)}

CA: San Luis Obispo County, Montana de Oro State Park, Sandspit Parking Lot Northeast Trail; 17 August 2014; FEK and KEK. Host: Tigrosa grandis, adult female, $21 \mathrm{~mm}$ (wasp, $17.5 \mathrm{~mm}$ ). Another female searching for a host spider at the same locality on 24 August 2014 traveled over $45 \mathrm{~m}$ in less than 5 minutes during an unsuccessful hunting excursion (F.E. Kurczewski and K.E. Kurczewski, 2014 pers. observ.).

ID: Ada County, Boise; 1 August 2016, 1919 (PDT); Nick. Host: Schizocosa ?mccooki Montgomery, adult female (gravid). The wasp pulled the paralyzed spider backwards up a vertical wall, grasping its right pedipalp with her mandibles. The paralysis was incomplete, and the spider kept moving its appendages during transport (Nick 2016).

\section{Anoplius (Lophopompilus) aethiops (Cresson)}

ME: Kennebec County, South China, overgrown lawn next to hayfield; 7 September 2014; W.H. Wilson. Host: Tigrosa helluo, adult female, $20 \mathrm{~mm}$ (wasp, $20 \mathrm{~mm}$ ). The wasp dragged the paralyzed spider backwards through uncut grass, grasping the base of its left foreleg with her mandibles while holding it in an almost upright perpendicular position (Wilson 2014; W.H. Wilson, Colby College, Waterville, ME, 2015 pers. comm.).

NJ: Cape May County, Cape May Point State Park; 1 October 2012; E.R. Eaton. Host: Tigrosa helluo, subadult female. The wasp was 1.3 times the body length of the spider. She dragged the spider backwards across a sandy path in dense vegetation, holding it upright and perpendicular to her body, and grasping it with her mandibles by the base of its $3^{\text {rd }}$ right leg. The wasp eventually left the spider on the ground surface (Eaton 2012b; E.R. Eaton, 2013 pers. comm.).

NY: Onondaga County, Syracuse, Onondaga Hill; 15 September 2015; M. and S. MacDerment. Host: Tigrosa helluo, adult female, $2^{\text {nd }}$ right leg amputated at coxa-trochanter joint, $20 \mathrm{~mm}$. The wasp released the spider dorsal side upward on an asphalt driveway next to a garage (M. and S. MacDerment, Syracuse, NY, 2015 pers. comm.).

OK: Latimer County, Wilburton; 26 November 2009: J.D. Kouri. Host: Rabidosa punctulata, adult or subadult female. The wasp grasped the paralyzed spider with her mandibles by the base of its right hindleg and carried it across twigs and other vegetation (Kouri 2009; J.D. Kouri, Wilburton, OK, 2015 pers. comm.).

\section{Anoplius (Lophopompilus) atrox (Dahlbom)}

MO: Holt County, Mound City, Squaw River National Wildlife Reserve, road through open grassland with native plants, scrubby brush and grasses near wetlands; 11 August 2014; S. Cox. Host: Rabidosa rabida, adult female. The wasp and spider were equivalent in body length. The wasp grasped the base of the spider's right hindcoxa with her mandibles and walked backwards across the road, maintaining the spider in an almost upright perpendicular position relative to her own body. She paused, released the spider periodically, dorsal side upward, and then resumed transport (Cox 2014; S. Cox, 2014 pers. comm.). 
TX: [Northern] Liberty County, Big Thicket National Preserve; 27 March 2013; J.M. Smith. Host: Hogna or Tigrosa sp., adult or subadult female, $18 \mathrm{~mm}$ (wasp, $19.6 \mathrm{~mm})$. The wasp examined the spider with her antennae and mouthparts after stinging it (J.M. Smith, 2014 pers. comm.).

VA: Independent City of Alexandria, damp forest; 23 June 2004; M. Moran. Host: Dolomedes tenebrosus, adult female. The wasp dragged the paralyzed spider backwards on the ground, dorsal side upward, grasping the spider's pedipalp with her mandibles. She periodically paused, released the spider, dorsal side upward, and circled it (Moran 2004).

\section{Anoplius (Lophopompilus) carolina (Banks)}

WV: Upshur County, near Ruraldale, margin of oak-hickory forest near pond and wetlands; 18 July 2008; S. Creswell. Host: Coras or Wadotes sp. (Amaurobiidae), adult or penultimate female. The wasp dragged the spider backwards on the ground in open woodland on its right side, grasping the base of its right foreleg or pedipalp with her mandibles. She paused repeatedly, released the spider, and rested on dried leaves or soil (Creswell 2012b; S. Creswell, 2014 pers. comm.).

\section{Anoplius (Lophopompilus) cleora Banks}

KS: Geary County, Milford, near Milford Lake, sand beach; 3 October 2013; KC Wildlife. Host: Arctosa littoralis (Hentz) (Shoreline Sand Spider), adult or subadult female. The wasp pulled the spider backwards on sand, grasping it by the base of a hindleg with her mandibles. During transport, the spider was held upright in a perpendicular position (KC Wildlife 2013).

MA: Barnstable County, Wellfleet, sand beach; 19 August 2014; T. Murray. Host: Arctosa littoralis, adult female. The wasp dragged the spider backwards across sand, grasping the base of its $3^{\text {rd }}$ or $4^{\text {th }}$ right leg with her mandibles and holding it in an almost upright perpendicular position (Murray 2014a).

MA: Essex County, Newburyport, small inland area of sand dunes; 12 July 2008; B. Zaremba. Host: Arctosa littoralis, adult female. The wasp dragged the paralyzed spider backwards across sand, grasping it by the base of the $3^{\text {rd }}$ or $4^{\text {th }}$ right leg with her mandibles while holding it in a perpendicular position (Zaremba 2008a; B. Zaremba, Newburyport, MA. 2015 pers. comm.).

NY: Jefferson County, Southwick Beach State Park, sand beach; 17 September 2014, 1614 (EDT), $23{ }^{\circ} \mathrm{C}$; FEK. Host: Arctosa littoralis, adult female, $14.5 \mathrm{~mm}$ (wasp, $15.5 \mathrm{~mm}$ ). The wasp excavated a burrow in bare sand at the edge of the beach with the spider lying dorsal side upward on the sand $\sim 10 \mathrm{~cm}$ from the opening (F.E. Kurczewski, 2014 pers. observ.).

\section{Anoplius (Notiochares) lepidus atramentarius (Dahlbom)}

OK: Cleveland County, Lexington Wildlife Management Area, hard-packed sandy trail through crosstimbers habitat near Lake Dahlgren; 17 September 2015; B.E. Reynolds. Host: Rabidosa punctulata, penultimate male. The wasp pulled the paralyzed spider backwards across a trail, grasping a leg with her mandibles. She 
released the spider on its left side on the trail whereupon the pair was photographed (Reynolds 2015b; B.E. Reynolds, 2015 pers. comm.).

\section{Anoplius (Arachnophroctonus) americanus ambiguus (Dahlbom)}

CA: San Bernardino County, Mohave Desert, Afton Canyon, sand/muck of partly dry Mohave River bed; 15 September 2005; J. Gross. Host: Arctosa littoralis, subadult female. The spider was grasped with the wasp's mandibles by the base of its $3^{\text {rd }}$ left leg, held perpendicularly upright above the ground, and dragged backwards (Fig. 22). Periodically, the wasp released her prey on the ground to examine it with her antennae and mouthparts. She dragged it across the river bed for $1.8 \mathrm{~m}$, released the spider on the ground, dorsal side upward, went inside her burrow, turned around, exited headfirst, grasped the spider by its spinnerets with her mandibles, and pulled it into the opening (Gross 2005; J. Gross, University of California, Berkeley, CA, 2014 pers. comm.).

CA: Orange County, Irvine, San Joaquin Marsh Reserve; 22 July 2013; R. Hemberger. Host: Arctosa littoralis, adult female. The wasp examined the recently stung and paralyzed spider, which laid ventral side upward with all legs spread laterally, with her mouthparts and antennae. She then grasped its right foreleg with her mandibles about midway from the end and began dragging it backwards on the ground, dorsal side upward (Hemberger 2013; R. Hemberger, Irvine, CA, 2013 pers. comm.).

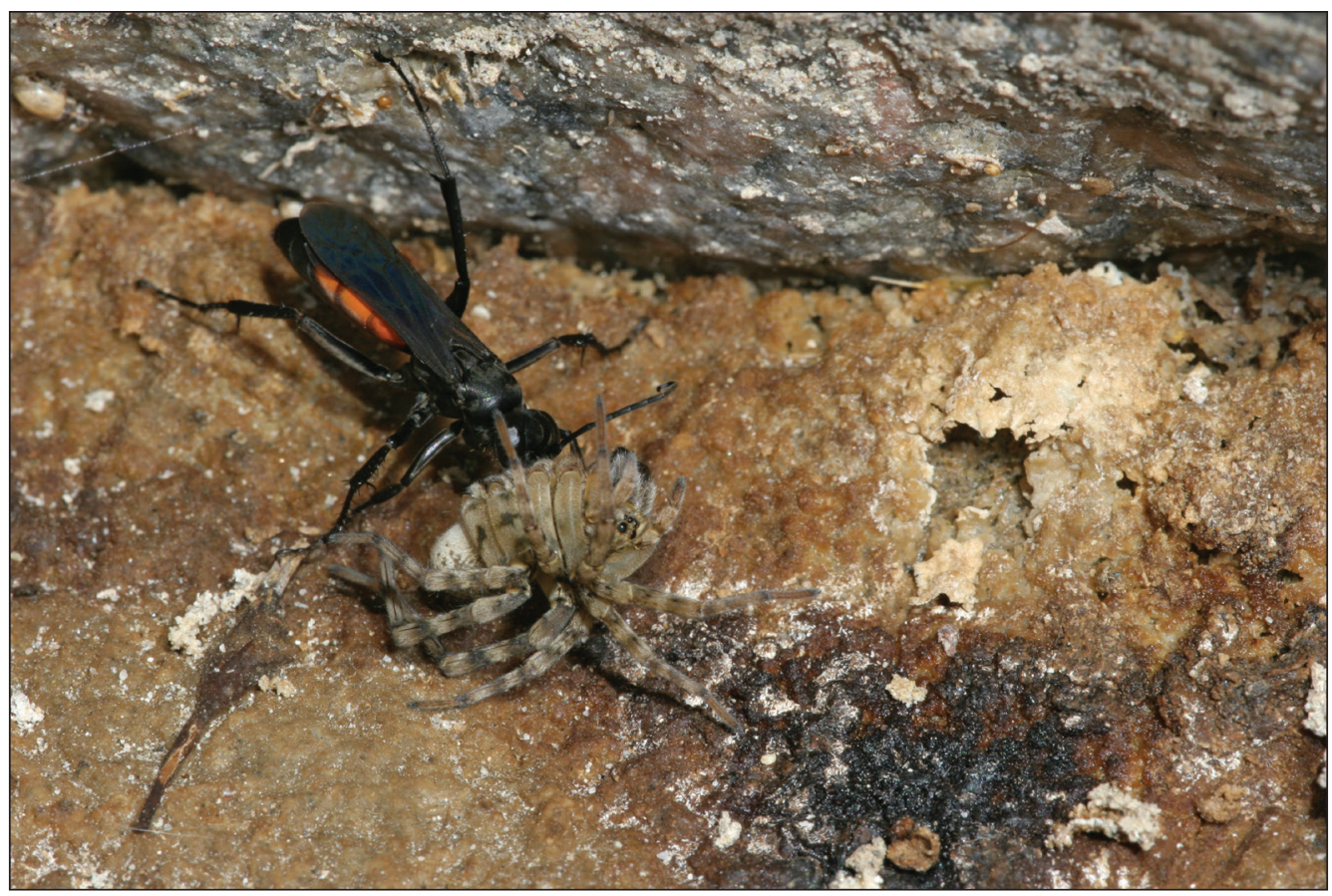

Figure 22. Anoplius americanus ambiguus female grasps a paralyzed Arctosa littoralis subadult female by the base of its $3^{\text {rd }}$ left leg with her mandibles, holds the spider in a perpendicular upright position, and drags it backwards on the ground (J. Gross, 2014 pers. comm.). 
TX: El Paso County, El Paso; 11 August 2015; S. Vitanza. Host: Tigrosa annexa (Chamberlin) (Field Wolf Spider), adult or subadult female. The wasp dragged the paralyzed spider backwards, grasping its left pedipalp with her mandibles (S. Vitanza, El Paso, TX, 2016 pers. comm.).

\section{Anoplius (Arachnophroctonus) apiculatus autumnalis (Banks)}

IL: Lake County, Illinois Beach State Park, sand beach; 15 August 2006; R. Curtis. Host: Arctosa littoralis, immature (R. Curtis, 2016 pers. comm.).

NY: Jefferson County, Southwick Beach State Park, sand beach; 17 September 2014, 1511 (EDT), $23{ }^{\circ} \mathrm{C}$; FEK. Host: Arctosa littoralis, immature, $7 \mathrm{~mm}$ (wasp, $9.5 \mathrm{~mm}$ ). The wasp excavated a burrow in sand; the spider was positioned dorsal side upward on the sand surface beside the excavation (F.E. Kurczewski, 2014 pers. observ.).

\section{Anoplius (Arachnophroctonus) nigritus (Dahlbom)}

IL: Cook County, Palos Park, McClaughry Springs Woods Forest Preserve; 30 June 2006; R. Curtis. Host: Schizocosa ?ocreata (Hentz), adult female (Lycosidae). The wasp approached the paralyzed spider, which laid motionless atop a flat rock, and examined it with her antennae and mouthparts. She then walked away and resumed excavating a burrow in the sloping soil of a stream bank (Curtis 2006; R. Curtis, 2014 pers. comm.).

\section{Anoplius (Arachnophroctonus) semicinctus (Dahlbom)}

IL: Lake County, Illinois Beach State Park, sand beach and dunes; 28 August 2016; R. Curtis, S. Ivanov (separate accounts). Host: Geolycosa wrighti (Emerton) (Burrowing Wolf Spider), adult female, $16.5 \mathrm{~mm}$ (wasp, $16.5 \mathrm{~mm}$ ). The small size of the female spider's abdomen and late summer date indicate she has already laid her eggs and her loss will not affect the spider species population size (see McQueen 1978). Several photographs and an $\sim 8$-minute video reveal the following behavioral information. The wasp spent a considerable amount of time for burrow excavation. She did not use the spider's burrow for a nest. She excavated in sand dunes using her forelegs alternately, pausing periodically to clean her antennae of moist sand with her forelegs. Following paralysis of the host spider, the wasp examined it with her antennae as it laid dorsal or ventral side upward on the sand surface. She took $>1$ hour to pull the spider across the sand dunes to her burrow as the sand constantly shifted beneath the pair. During ground transport, the wasp grasped the paralyzed spider by the base of a $1^{\text {st }}, 2^{\text {nd }}$, or $4^{\text {th }} l$ leg, end of $1^{\text {st }}$ or $2^{\text {nd }} l e g$, or end of either pedipalp (Fig. 23). She proceeded across the shifting sand surface very slowly and with much difficulty due to the relatively heavy weight of the spider. At one point, as the spider moved its legs, she re-stung it in its cephalothorax, between the bases of its $1^{\text {st }}$ and $2^{\text {nd }}$ pair of legs, for $1 \mathrm{sec}$. After arriving at the burrow entrance, the wasp deposited the spider, which was still moving its legs, in the left half of the entrance and continued to remove sand from the burrow using her forelegs alternately (Ivanov 2016b; R. Curtis, 2016 pers. comm.). 


\section{Anoplius (Arachnophroctonus) semirufus (Cresson)}

IL: Lake County, Illinois Beach State Park, edge of beach and open woodland trail behind beach; 15 August 2006; R. Curtis. Host: Varacosa avara (Keyserling), penultimate female, immature female ( 2 records). One wasp cached her paralyzed spider, dorsal side upward, on an overhanging leaf in open woodland (R. Curtis, 2016 pers. comm.).

\section{Anoplius (Pompilinus) marginatus (Say) species-complex}

IL: Lake County, Illinois Beach State Park; 19 July 2015; M. Swanson. Host: Phidippus clarus, adult female. The wasp cached the paralyzed spider above ground on broad-leaf grass (Swanson 2015; M. Swanson, Swanson Media, Evanston, IL, 2015 pers. comm.).

WV: Greenbrier County, Ronceverte, loamy soil of garden; 13 July 2014, 1204 (EDT); FEK. Host: Trochosa sp., penultimate female, $9.5 \mathrm{~mm}$ (wasp, $10.5 \mathrm{~mm}$ ). The wasp dragged the spider backwards through a garden, grasping its hindleg with her mandibles and holding it in a nearly upright perpendicular position (F.E. Kurczewski, 2014 pers. observ.).

ON, CANADA: Northumberland County, Brighton, on sand; 20 July 2009; N. Smith. Host: Trochosa terricola, adult or subadult female, $9 \mathrm{~mm}$ (wasp, $10 \mathrm{~mm}$ ). The wasp examined the paralyzed spider, which laid dorsal side upward on the sand surface, with her antennae and mouthparts before attempting to transport it (Smith 2009b; N. Smith, 2014 pers. comm.).

ON, CANADA: Northumberland County, Brighton; 2 July 2010, 1751 (EDT); N. Smith. Host: Trochosa terricola, adult or subadult female, 9.5 (wasp, $10 \mathrm{~mm}$ ). The wasp released the spider on the ground, dorsal side upward, and searched for her nest entrance, pausing periodically to clean herself with her forelegs (Smith 2010b; N. Smith, 2013 and 2014 pers. comm.).

Figure 23. Anoplius semicinctus female grasps femur of $3^{\text {rd }}$ right leg of Geolycosa wrighti adult female with her mandibles prior to dragging it backwards across sand dunes (R. Curtis, 2016 pers. comm).

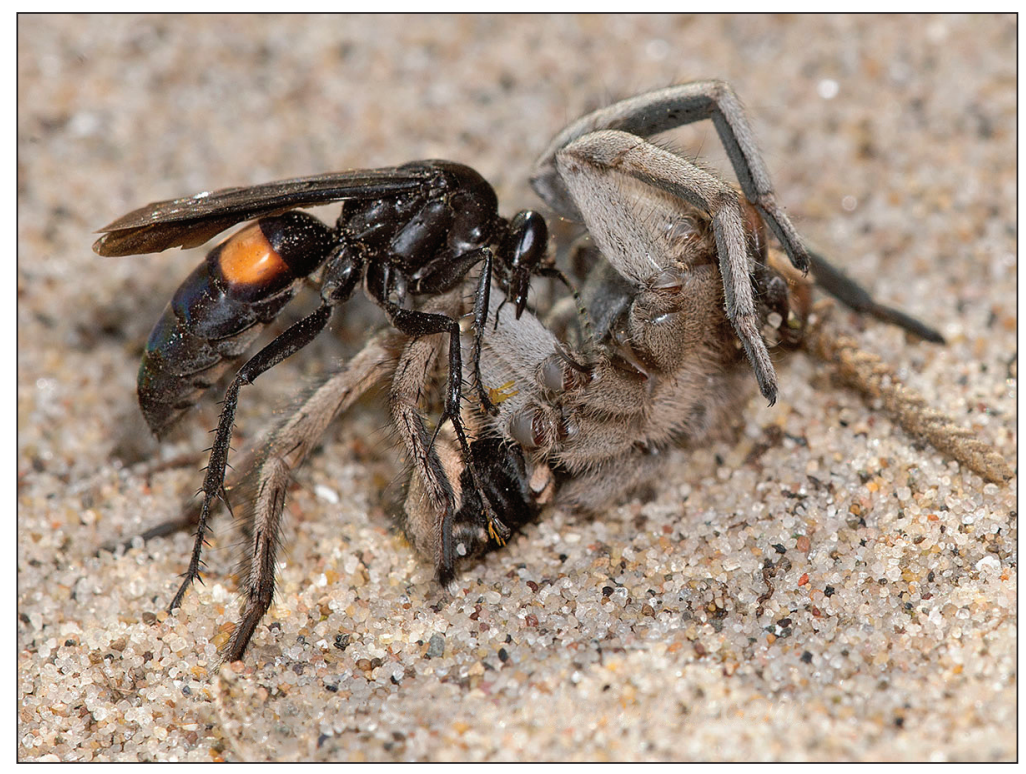




\section{Anoplius (Pompilinus) ?splendens (Dreisbach)}

MA: Barnstable County, Wellfleet, sand beach; 19 August 2014; T. Murray. Host: Amaurobiidae, adult female. The wasp examined the spider with her antennae and mouthparts as it laid dorsal side upward on the sand surface (Murray 2014b).

\section{Anoplius (Pompilinus) tenebrosus (Cresson)}

MA: Middlesex County, Concord; 2 May 2005; R.K. Walton. Host: Thanatus sp., possibly formicinus (Olivier) (Philodromidae) (Running Crab Spider), adult female, $8 \mathrm{~mm}$ (wasp, $12 \mathrm{~mm}$ ). The wasp was finishing the excavation of her burrow in bare ground. Her paralyzed spider was placed ventral side upward with its face a few $\mathrm{mm}$ from the opening (R.K. Walton, 2014 pers. comm.).

MA: Middlesex County, Concord, glacial sand plain; 7 May 2014; R.K. Walton. Host: Zelotes sp. (Gnaphosidae), adult female (R.K Walton, 2014 pers. comm.).

MA: Middlesex County, Sherborn; 6 May 2008; B. Zaremba. Host: Naphrys pulex (Hentz) or Sitticus sp. (Salticidae), immature. The wasp examined the paralyzed spider, which was positioned ventral side upward on the sand, with its antennae and mouthparts (Zaremba 2008b).

AB, CANADA: Banff National Park, dry silty ridge; 30 April 2013; M.D. McIvor. Host: Trochosa sp., adult female (gravid). The wasp dragged the spider backwards on the ground, grasping the coxa of its $3^{\text {rd }}$ left leg with her mandibles. She paused at least once to examine the prey with her antennae and mouthparts (McIvor 2013).

QC, CANADA: Blainville; 30 April 2009; R. Ganz. Host: Xysticus sp. (Thomisidae), adult female. A series of photos shows the wasp excavating her burrow in sandy soil with the paralyzed crab spider lying dorsal side upward on sand in front of the excavation (Ganz 2009).

QC, CANADA: Saint Simeon, near Saguenay Fjord, dry sandy area surrounded by coniferous woodland; 18 June 2011; P. Moniotte. Hosts: Trochosa sp. (Lycosidae), adult or subadult female; Xysticus sp. (Thomisidae), adult female. Two conspecific wasps fought viciously, biting with the mandibles and attempting to sting each another near the paralyzed Trochosa sp. lying on the sand surface. A larger wasp dragged the Xysticus sp. backwards, dorsal side upward, grasping the base of its right foreleg with her mandibles, to within $1 \mathrm{~cm}$ of her burrow entrance and released it ventral side upward on the sand surface (Fig. 24; Moniotte 2011; P. Moniotte, Saint Simeon, QC, Canada, 2013 pers. comm.).

\section{Anoplius (Anoplius) depressipes Banks}

IL: Cook County, Glenview, Harms Woods, along North Branch Chicago River; 7 September 2012; J. and J. Balaban. Host: Pisaurina mira, subadult female. The wasp dragged the paralyzed spider backwards, dorsal side upward, grasping its $3^{\text {rd }}$ left leg with her mandibles, across a Saururus cernuus L. (Lizard's Tail) (Saururaceae) leaf. She wedged the spider in the leaf axil, walked a short distance away, and cleaned herself with her forelegs. She returned to the spider, grasped it as before, flew downward to a lower leaf, and disappeared (Balaban and Balaban 2012; J. and J. Balaban, Skokie, IL, 2015 pers.comm.). 
OK: Cleveland County, Lexington Wildlife Management Area; 8 October 2005; B.E. Reynolds. Host: Pisaurina mira, adult female, $15 \mathrm{~mm}$ (wasp, $15 \mathrm{~mm}$ ). The wasp pulled the spider backwards, dorsal side upward, across a gravel access path next to a marsh, grasping it with her mandibles by the spider's left foreleg or pedipalp (Fig. 25). She dragged the spider to the edge of the path and then disappeared into high vegetation (Reynolds 2005; B.E. Reynolds, 2014 pers. comm.).

TX: Harris County, near LaPorte, marshy area surrounded by bay near San Jacinto Monument; 6 June 2009, 0926 (CDT); T.P. Villalobos. Host: Dolomedes triton (Walckenaer) (Six-spotted Fishing Spider), adult male. The wasp dragged the paralyzed spider, at times on its right side, toward a preexisting burrow, a simple hole in the ground, grasping its left foreleg with her mandibles (Villalobos 2009; T.P. Villalobos, Houston, TX, 2014 pers. comm.).

\section{Anoplius (Anoplius) fulgidus (Cresson)}

AZ: Cochise County, Huachuca Mountains, Miller Canyon, mesquite grassland to oak-juniper woodland, elevation 1585 m; 20 March 2009; C.W. Melton. Host: Rabidosa punctulata, adult or subadult female. The wasp and spider were about equal in body length. Two photos show the wasp examining the paralyzed spider with her antennae and mouthparts as it lay on the ground dorsal side upward (Fig. 26; Melton 2009; C.W. Melton, 2014 pers. comm.).

CA: Los Angeles County, San Pedro, driveway; 16 June 2013; R. Ransom. Host: Hololena ?curta (McCook) (Agelenidae) (Corner Funnel Weaver), adult female, $9.5 \mathrm{~mm}$ (wasp, $11.1 \mathrm{~mm}$ ). The spider had its $3^{\text {rd }}$ right leg amputated at the coxa-trochanter joints and its $2^{\text {nd }}$ right leg was much smaller than the other legs,

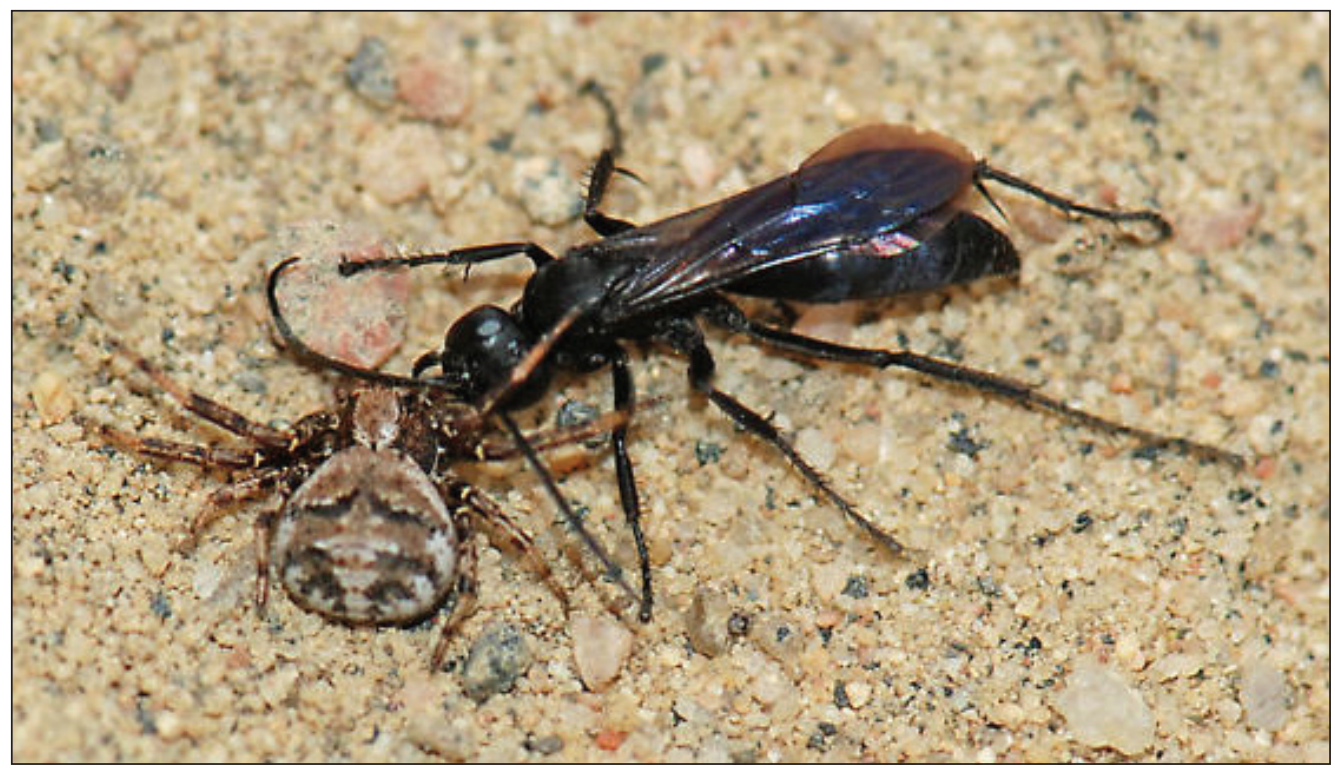

Figure 24. Anoplius tenebrosus female drags a paralyzed Xysticus sp. adult female, dorsal side upward, backwards on the ground, grasping the base of its right foreleg with her mandibles (P. Moniotte, 2013 pers. comm.). 
apparently having been lost and regrown. The wasp dragged the spider backwards, grasping the base of its $3^{\text {rd }}$ left leg with her mandibles while maintaining it in an almost upright perpendicular position (Back Cover). The wasp periodically released the spider on a cactus pad and examined it before arriving at her nest entrance. She

Figure 25. Anoplius depressipes female drags a paralyzed Pisaurina mira adult female backwards across a path next to a marsh, grasping it with her mandibles by the spider's left foreleg or pedipalp (B.E. Reynolds, 2014 pers. comm.).

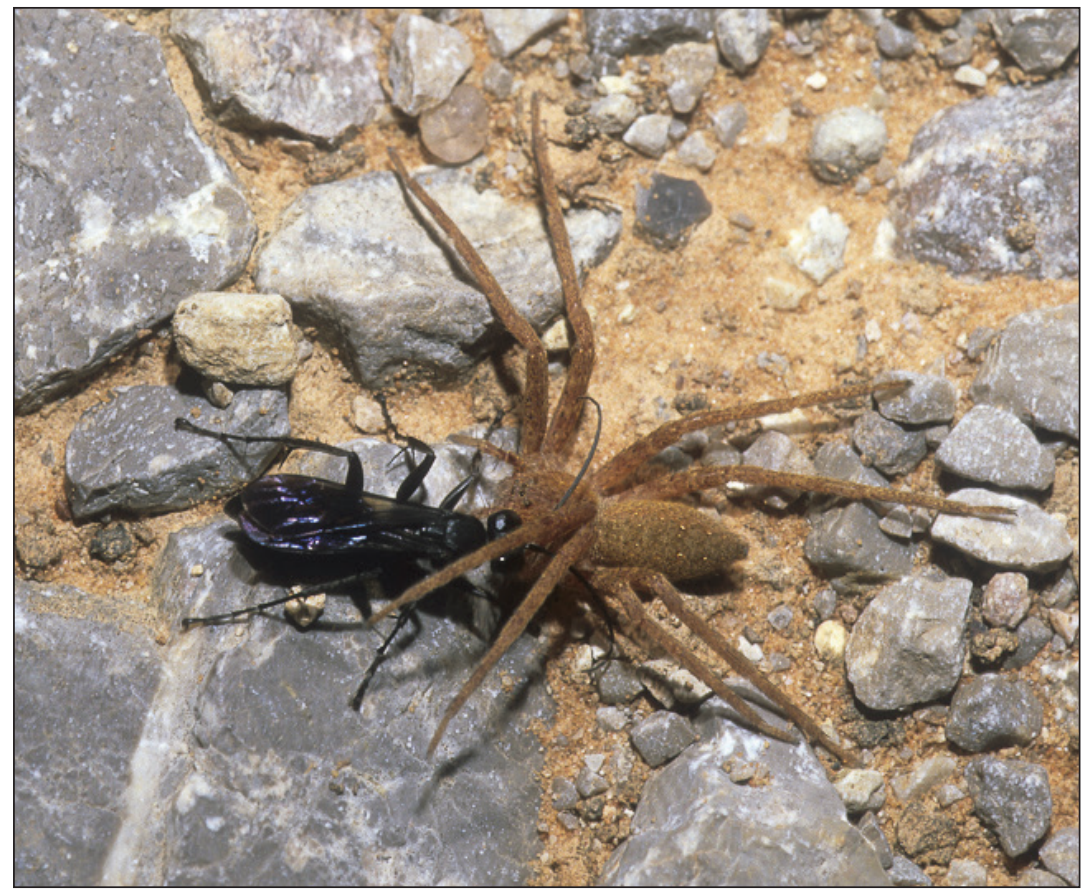

Figure 26. A n o plius fulgidus female uses her antennae and mouthparts to examine a paralyzed $R a$ bidosa punctulata adult or subadult female as it lies dorsal side upward on the ground (C.W. Melton, 2014 pers. comm.).

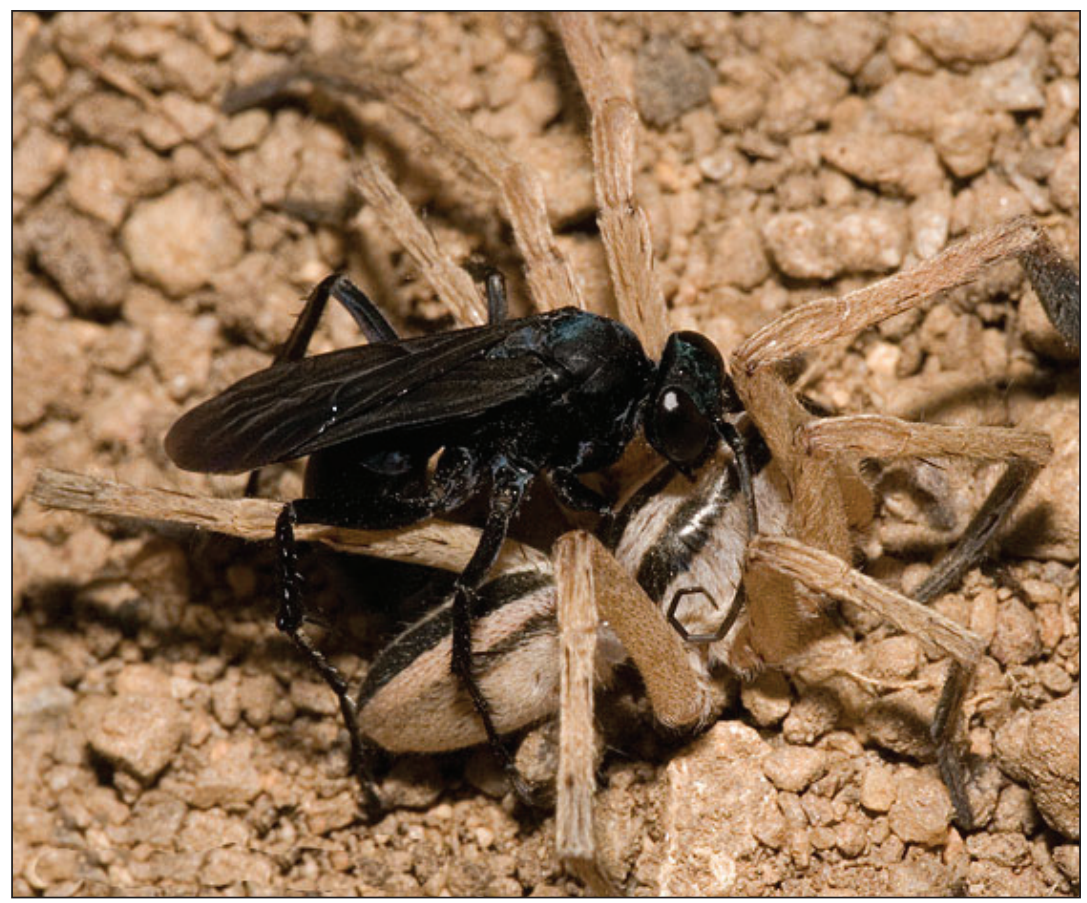


nested in a crevasse in soil of a potted cactus (Ransom 2013; R. Ransom, San Pedro, CA, 2015 pers. comm.).

\section{Anoplius (Anoplius) illinoensis (Robertson) or Anoplius (Anoplius) ventralis (Banks)}

IL: Cook County, Glenview, Glenview Park District, Kent Fuller Air Station Prairie, gravelly/sandy soil with large rocks and stone wall; 16 September 2016; S. Ivanov. Hosts: Tigrosa helluo, penultimate male, 12-13 mm (wasp, 12-13 mm); Agelenopsis sp., subadult female. The wasp dragged the paralyzed T. helluo backwards across a gravel trail, grasping the base of its $2^{\text {nd }}$ right leg with her mandibles. Later in the day, she pulled the paralyzed Agelenopsis sp. backwards up a stone wall, grasping it by the base of its pedipalp/chelicera with her mandibles. After reaching a height of $30 \mathrm{~cm}$ above ground, she dragged the spider into a crevice between 2 large stones, a small area with gravelly/sandy soil (Ivanov 2016c; S. Ivanov, Glenview, IL, 2016 pers. comm.).

\section{Anoplius (Anoplius) imbellis Banks}

ME: Cumberland County, Scarborough, a dike across a seaside or tidal marsh; 20 June 2015; R. Curtis. Host: Trochosa ruricola or T. terricola. Based on 3 photographs, it appears the wasp released the paralyzed spider, dorsal side upward, and examined it with her antennae (Curtis 2016; R. Curtis, 2016 pers. comm.).

NY: Onondaga County, Syracuse, Onondaga Hill, loamy-gravelly soil; 1-2 October 2013, 1226-1647 (EDT), $21-23{ }^{\circ} \mathrm{C}$; FEK. Host: Trochosa ruricola, adult female, $9 \mathrm{~mm}$ (wasp, $10 \mathrm{~mm}$, 2nd generation). The wasp nested in a pile of pebbles deposited at the site in the spring. She dragged her host spider backwards across the pebbles and entered an opening between 2 small stones, grasping the prey with her mandibles by the base of its right hindleg until at the opening. She then turned, grasped its spinnerets with her mandibles, and backed into the hole. She remained below ground for 4.5 minutes, emerged headfirst, and dragged small twigs, dried moss, and tiny clumps of agglutinated soil into the opening with her mandibles, then backed repeatedly into the opening using this debris as fill. After filling the entrance more or less flush with the surface, she spent 7 minutes bringing dried leaflets that had fallen from a nearby Gleditsia triacanthos L. (Honey Locust) tree and piled these atop the fill with her mandibles. She brought 13 leaflets to conceal the area of the entrance. Upon excavation of the nest, the roughly shaped tubular tunnel was filled with the moist debris. A crude chamber was located $28 \mathrm{~mm}$ below the top of the pile of pebbles. It contained the paralyzed spider in a head-outward and dorsal-side-upward position. The wasp's egg, $\sim 2 \mathrm{~mm}$ long, was affixed to the left side of the spider's abdomen about midway from the base. Two other wasps, 7 and $9 \mathrm{~mm}$ long, nested in bare silt loam about $1 \mathrm{~m}$ away. These females excavated non-provisioned and unfinished burrows $14.5 \mathrm{~cm}$ apart (F.E. Kurczewski, 2013 pers. observ.).

NY: Onondaga County, Syracuse, Onondaga Hill, loamy-gravelly soil; 6-7 September 2015, 0911-1613 (EDT), 25-31 ${ }^{\circ} \mathrm{C}$; FEK. Host: Trochosa sp. probably 
ruricola, juvenile, $8.5 \mathrm{~mm}$ (wasp, $10 \mathrm{~mm}$, complete wings, recent $2^{\text {nd }}$ generation emergent). The wasp cached her paralyzed spider, ventral side upward, in the axile of a Hieracium caespitosum Dumort (Yellow King-devil) (Asteraceae) plant, $8 \mathrm{~cm}$ above ground. With her mandibles, legs and end of abdomen, she enlarged a preexisting depression in the ground $1.2 \mathrm{~m}$ away, presumably to use as a nest. Another female nearby searching for spiders passed by 2 active Agelenopsis funnel-webs without entering either web (F.E. Kurczewski, 2015 pers. observ.).

\section{Anoplius (Anoplius) ithaca (Banks)}

ON, CANADA: Ottawa, Deschênes Rapid Lookout on the Ottawa River; 22 August 2016; G. Johnston. Host: Pardosa lapidicina Emerton (Stone Wolf Spider) or P. xerampelina (Keyserling) (River Bank Wolf Spider), penultimate or juvenile male. The wasp was 1.4 times as long as the spider. The wasp dragged the paralyzed spider backwards a distance of $\sim 1 \mathrm{~m}$ across a large ornamental stone in a riverfront park, disappearing down a crevice above a stony beach. Using her mandibles, she varied her grasp of the spider's legs from the base of the right front leg to the end of the left $3^{\text {rd }}$ leg (Johnston 2016; G. Johnston, Ottawa, ON, Canada, 2016 pers. comm.).

\section{Anoplius (Anoplius) virginiensis (Cresson)}

MA: Hampshire County, Pelham, backyard next to woods; 9 October 2011; C. Eiseman. Host: Trochosa terricola, adult female, $9 \mathrm{~mm}$ (wasp, $12 \mathrm{~mm}$ ). She stung and paralyzed the lycosid and then dragged it backwards on the ground, grasping it with her mandibles by the base of a hindleg while maintaining it in an upright perpendicular position. She climbed a stone wall, and her spider got caught in a peripheral thread from the web of a female Steatoda borealis (Hentz) (Theridiidae) (Northern Cobweb Weaver). After trying unsuccessfully to free the spider, the wasp fell to the ground and began running on the ground interspersed with episodes of returning to the spider and trying to loosen it by biting at the base of its right foreleg (Fig. 27). The spider's $2^{\text {nd }}$ right leg had evidently already been cut off at the coxa-trochanter joint by the wasp's mandibles in an attempt to loosen the prey. The S. borealis, 6-7 $\mathrm{mm}$ in body length, ran toward the wasp as she attempted to free the host spider but then quickly turned around and ran back to her retreat. Seconds later, the wasp freed the lycosid and, after it dropped to the ground, she ran to it and resumed dragging it behind her as it was now attached to her hindleg by silk threads. She alternated between prey transport and attempting to shed the Steatoda web and other attached debris using her mandibles and legs. The wasp periodically paused, released the spider, examined it, and appeared to sting it. She then left it on the ground and cleaned her antennae by pulling them through the tibio-tarsal cleaning apparatuses. After shedding the silk and debris from the lycosid, using her forelegs and mandibles, the wasp resumed dragging the spider to a secluded spot in the same manner as described above, released it, and began chewing at the bases of its legs with her mandibles. Eventually, she abandoned the spider, which remained in the same position through the following morning (Eiseman 2011; C. Eiseman 2014, 2015 pers. comm.). 
NY: Monroe County, Henrietta, backyard with flower garden $18 \mathrm{~m}$ from deciduous woodland; 17 July 2016; J. Greenberg. Host: Trochosa ruricola or T. terricola, adult female. The wasp's body length was 1.5 times that of the spider. The wasp grasped the paralyzed spider by the base of its left $1^{\text {st }}$ or $2^{\text {nd }}$ leg with her mandibles and dragged it backwards (Greenberg 2016; J. Greenberg, Rochester, NY, 2016 pers. comm.).

NY: Orange County, Warwick, atop a boulder at edge of a man-made pond surrounded by hardwood forest and meadow; 22 July 2016; J. Lampkin. Host: ?Tigrosa helluo, adult male, $10 \mathrm{~mm}$ (wasp, $12 \mathrm{~mm}$ ). The wasp pulled the paralyzed spider backwards, grasping the base of its $3^{\text {rd }}$ or $4^{\text {th }}$ left leg with her mandibles. She eventually released the spider and flew away (Lampkin 2016; J. Lampkin, 2016 pers. comm.).

\section{Perissopompilus phoenix Evans}

CA: Ventura County, Los Padres National Forest, Mount Pinos, elevation 2697 m; 4 September 2016; A. J. Abela. Host: Xysticus sp., adult female, $6.2 \mathrm{~mm}$ (wasp, $8.8 \mathrm{~mm}$ ). The wasp grasped the paralyzed spider by the base of its left or right foreleg with her mandibles and dragged it rapidly backwards over stony ground, pausing to examine it wither her antennae and mouthparts (Fig. 28; Abela 2016a, b; A.J. Abela, 2016 pers. comm.).

\section{Ammosphex angularis angularis (Banks)}

CA: San Luis Obispo County, Montana de Oro State Park, Sandspit Parking Lot Northeast Trail; 20 August 2014, 1219 (PDT); FEK. Host: Pardosa sp., penultimate

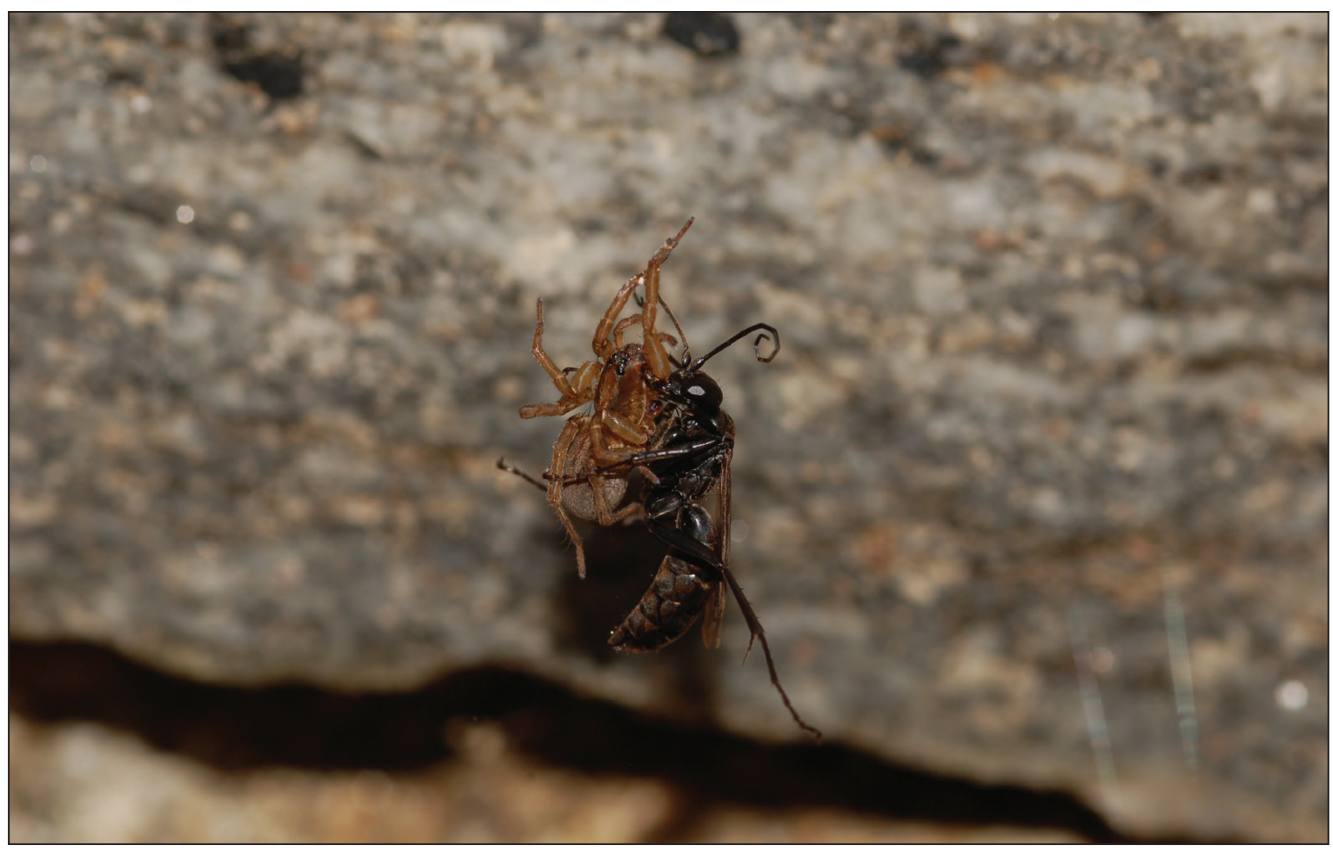

Figure 27. Anoplius virginiensis female attempts to free a paralyzed Trochosa terricola adult female entangled in a Steatoda borealis web by biting at the base of its right foreleg (C. Eiseman, 2014 pers. comm.). 
male, $4.5 \mathrm{~mm}$ (wasp, $6 \mathrm{~mm}$ ). The wasp pulled the paralyzed spider backwards on the sand, grasping the base of its hindleg with her mandibles while maintaining it in an upright, almost vertical position (F.E. Kurczewski, 2014 pers. observ.).

\section{Ammosphex michiganensis michiganensis (Dreisbach)}

SK, CANADA: White Fox, Torch River; 17 August 2013; S. McKechnie. Host: Xysticus sp., adult female. The wasp walked backwards between wood decking, grasping the spider by the base of its $3^{\text {rd }}$ left leg and holding it almost perpendicular to her body (McKechnie 2013; S. McKechnie, White Fox, SK, Canada, 2014 pers. comm.).

\section{Ammosphex solonus solonus (Banks)}

CA: Santa Barbara County, Burton Mesa Ecological Reserve, chaparral habitat dominated by La Purisima Manzanita (Arctostaphylos purissima P.V. Wells) (Ericaceae), sparsely vegetated clearing of partly consolidated sand; 10 April 2015; A.J. Abela. Host: Socalchemmis shantzi Platnick \& Ubick (Tengellidae), adult female, $11.6 \mathrm{~mm}$ (wasp, $9.2 \mathrm{~mm}$ ). (This is an extremely rare spider species found only in Santa Barbara and Ventura counties, CA). There is a series of 6 images showing various aspects of nesting behavior. The wasp dragged the spider some distance from vegetation onto open sand where she was in the early stages of digging a burrow. The wasp flung the sand backwards beneath her body, using her forelegs alternately (Fig. 29). The paralyzed spider laid in a ventral side upward position on

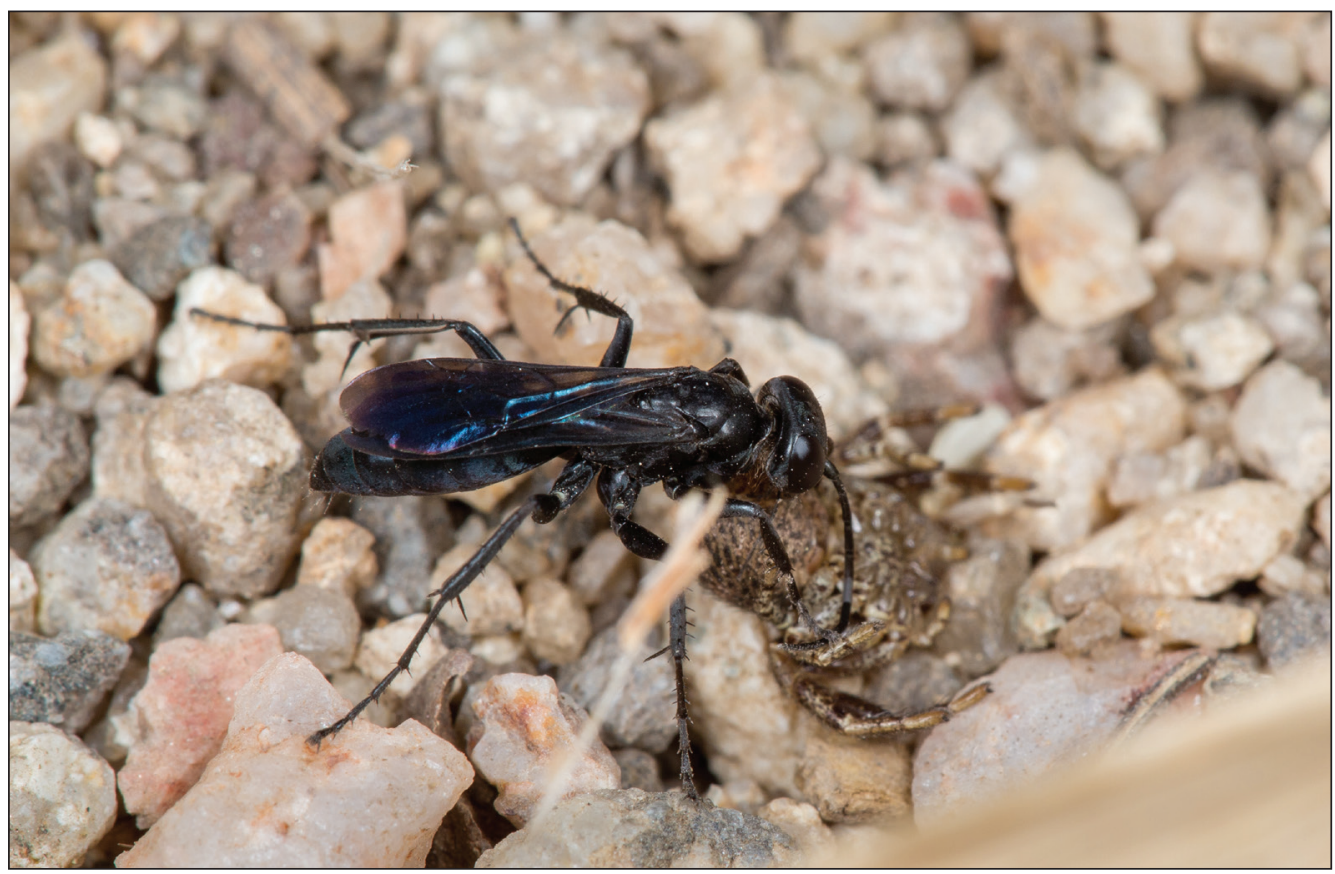

Figure 28. Perissopompilus phoenix female grasps Xysticus sp. adult female by base of foreleg with mandibles and drags it backwards over stony ground (A.J. Abela, 2016 pers. comm.). 
the sand surface $\sim 30 \mathrm{~cm}$ away. Later, the spider was turned over to obtain the dorsal side upward image (Fig. 30). Periodically, the wasp interrupted burrow excavation and walked across the sand to examine the paralyzed spider. She manipulated

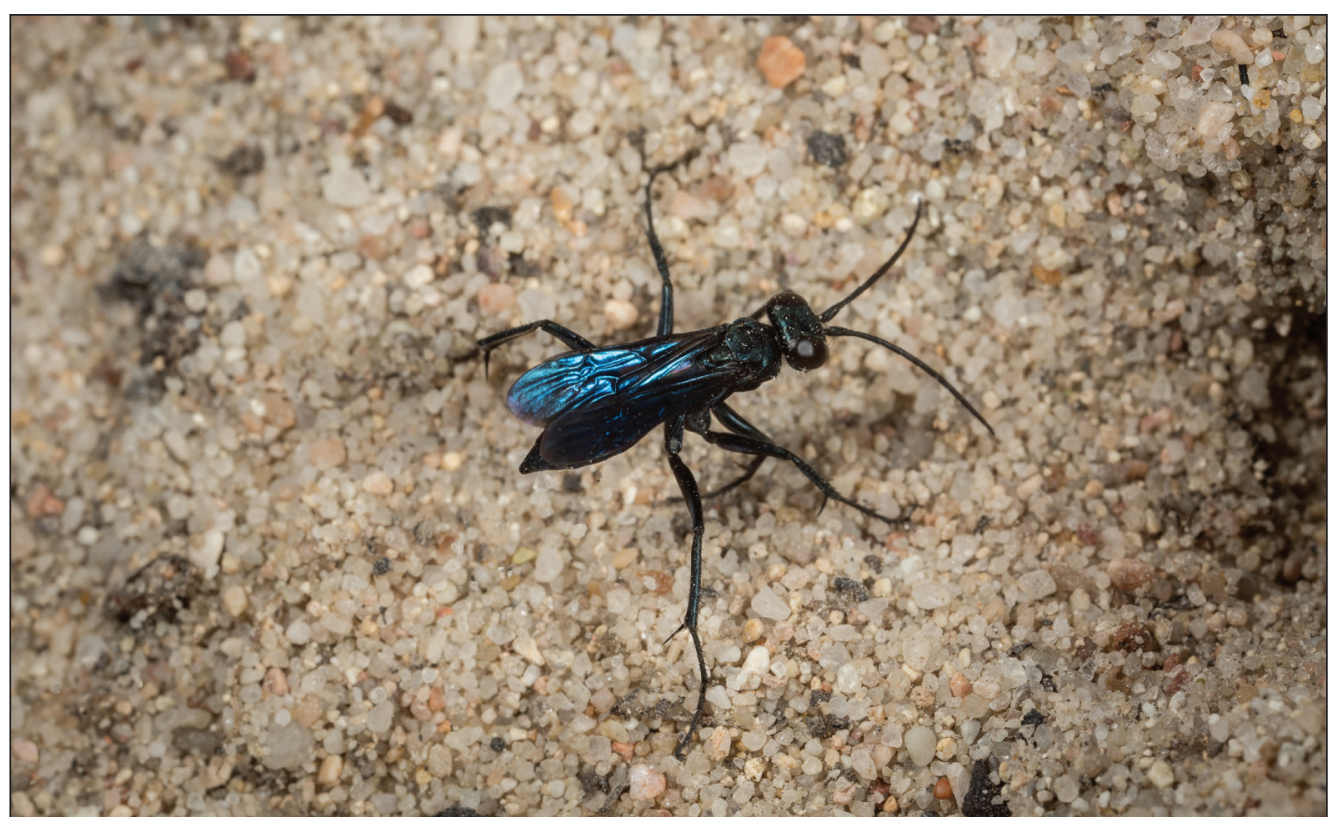

Figure 29. Ammosphex solonus female flings sand backwards beneath her body, using her forelegs alternately (A.J. Abela, 2015 pers. comm.).

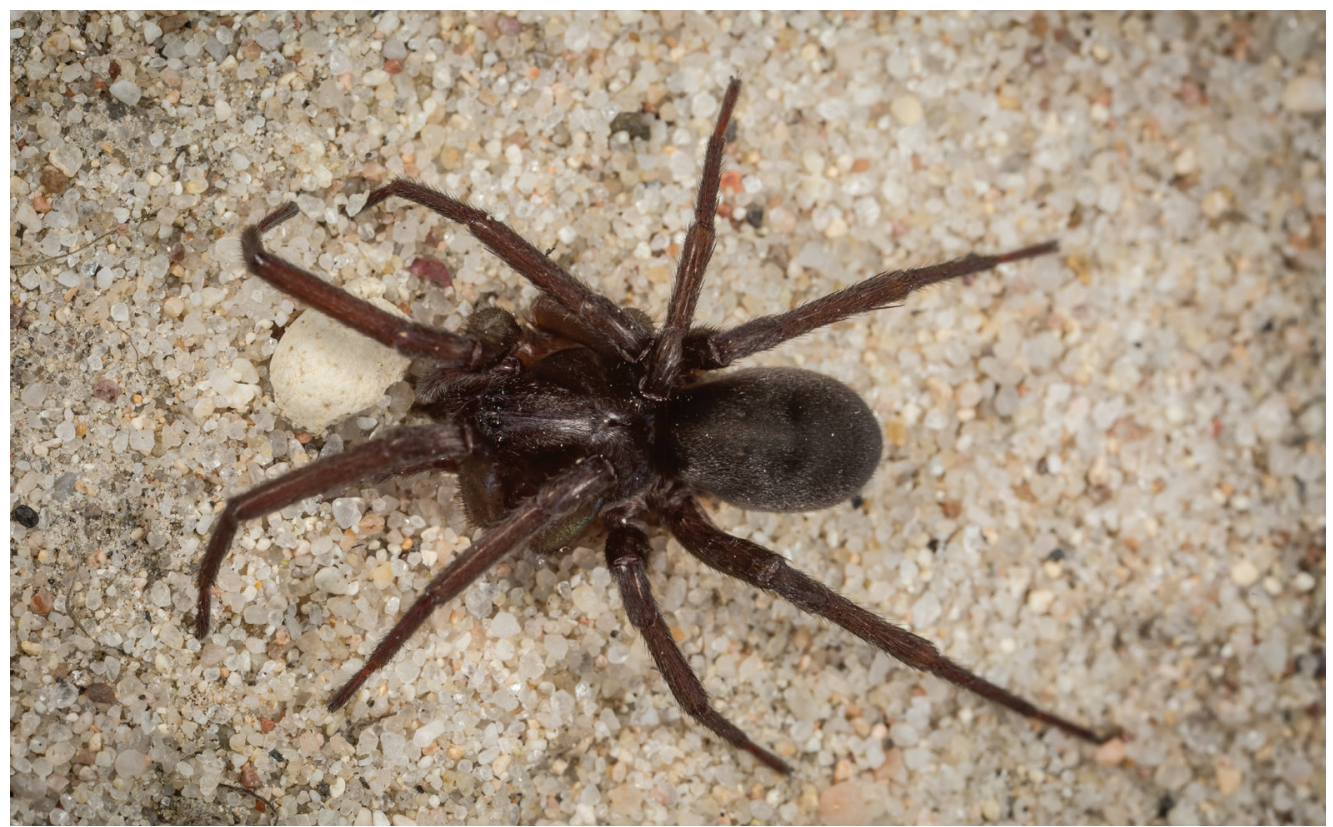

Figure 30. Paralyzed Socalchemmis schantzi adult female lies dorsal side upward on sand after being turned over for identification (A.J. Abela, 2015 pers. comm.). 
the spider by grasping it with her mandibles by the base of a leg or pedipalp (A.J. Abela, 2015 pers. comm.).

\section{Arachnospila arcta (Cresson)}

CA: San Luis Obispo County, Morro Bay, Inn at Morro Bay, sandy loam, 20-25 slope; 26-31 August 2014, 0831-1846 (PDT), 16-28 ${ }^{\circ} \mathrm{C}$; FEK. Hosts: Segestria sp. (Segestriidae) (Tube-web spider), subadult female, juvenile, 9.5, $9 \mathrm{~mm}$ (wasps, 11.5, $11 \mathrm{~mm}$ ); Hololena sp., penultimate female, $8.5 \mathrm{~mm}$ (wasp, $9.5 \mathrm{~mm}$ ). A recently emerged aggregation of this species was studied for 6 consecutive days (26-31 August 2014) in sunlit/shade conditions on a mainly bare, south-facing slope beneath a row of Eucalyptus globulus Labill (Myrtaceae) (Blue Gum) and Cupressus macrocarpa Hartweg (Cupressaceae) (Monterey Cypress) trees. Approximately 25 males occupied a $1-\mathrm{m}^{2}$ area, and another 10 males were in a $0.5-\mathrm{m}^{2}$ area located a distance of $5 \mathrm{~m}$ away. The males, 5.5-9.5 $\mathrm{mm}$ in body length, congregated on the ground in these areas as early as 0831-0837 at air temperatures as low as 16-17 ${ }^{\circ} \mathrm{C}$ and ground surface temperatures of $29-35{ }^{\circ} \mathrm{C}$. By noon, with higher air and soil temperatures, only a few males each occupied these areas. At the highest air and soil surface temperatures $\left(25-28{ }^{\circ} \mathrm{C},>50{ }^{\circ} \mathrm{C}\right.$, respectively), most males moved from the warm mainly bare slope to the cool level soil and plant litter beneath the Eucalyptus and Monterey Cypress trees. Males were observed there in the shade as late as 1846.

The males made quick 30-60-cm-long flights, landed on prominent features such as fallen leaves, bark, stones, plants, and raised areas of soil, and remained motionless for 1-2 seconds. The males then took flight or walked forward on the ground. At cool air $\left(16-17^{\circ} \mathrm{C}\right)$ and soil surface $\left(29-35^{\circ} \mathrm{C}\right)$ temperatures, flights were infrequent and walking prevailed. Males walked on the ground, tapped the soil surface with their antennae, and flicked their wings. As temperature increased, male flights increased in length, duration, and frequency. The amount of walking decreased correspondingly. One male chased another in rapid flight, sometimes landing atop it - perhaps mistaking it for a female. Grappling between males often followed such behavior. In such instances, the 2 males separated after 1-2 seconds and both wasps walked away with wings raised at an angle of $>45^{\circ}$.

Males spent most of their time searching for, scent-trailing, chasing, and attempting to mate with conspecific females. Nine males waited in an area for a female to emerge from the ground. They crawled over, nudged, and crowded in front of one another. As the female emerged, they swarmed rapidly around her and her emergence hole. All 9 males, almost in unison, simultaneously pursued her in an attempt to mate. However, only one male successfully ended atop her attached in the mating position. Males constantly disrupted burrow excavation, hunting, and provisioning by the females. When contacted by a male, such a female raised her wings to a nearly vertical position, flew away, landed, and cleaned her antennae and forelegs. Males pursued females hunting for spiders on and beneath dried, fallen Eucalyptus globulus leaves and Monterey Cypress needle litter. Males periodically examined female burrows with their antennae and, rarely, partly entered for 1-2 
seconds before backing out. Some males spent the night beneath leaves, bark, and other fallen debris or in burrows dug by conspecific females or other insects. Males have no structural modifications on the foretarsi with which to excavate a burrow and only very minute spines that no one would consider a fossorial comb.

Only 7 females, 6.5-11.5 $\mathrm{mm}$ in body length, were seen during the study and, perhaps, not all females in the aggregation had emerged. They appeared on the slope in the morning about 30 minutes after the appearance of the males: 09110918 at $17-18{ }^{\circ} \mathrm{C}$ (air temperature). They searched for spiders as late as 1742 and excavated burrows as late as 1746 at air temperatures of $19-25{ }^{\circ} \mathrm{C}$, often until shade covered the area. All females excavated a burrow before capturing a spider. Such burrows were dug beneath a dried Eucalyptus leaf, sprinkling system hose, flat stone, Monterey Cypress needle litter, decumbent plant (2), or at the base of a concrete retaining wall. Burrow entrances were 7-10 mm in diameter, larger openings being associated with larger wasps. Tumuli in front of the entrances ranged from 33 to $61 \mathrm{~mm}$ in length and 32 to $51 \mathrm{~mm}$ in width. The largest tumulus $(61 \mathrm{x}$ $51 \mathrm{~mm}$ ) was $21 \mathrm{~mm}$ high from the ground surface to the apex of the soil deposit. Larger tumuli were associated with longer and deeper nests and belonged to larger females. Smaller tumuli from shorter and shallower nests were usually made by smaller females.

Burrow excavation from beginning to end was observed only once. The female dug in sloped soil containing small bits of debris, mainly fallen plant litter, beginning at 1536. She dug using her mandibles and forelegs alternately to remove the loose soil and debris from the excavation. Damp soil, often as a 2-3-mm-wide agglutination, was removed with the mandibles. Narrow twigs, 6.5-29 mm long, were also removed from the excavation with the mandibles. As the female dug deeper, her entrance became plugged with damp soil and debris from below. The wasp periodically backed from her burrow to remove this accumulation, depositing it on the enlarging tumulus in front of her entrance. As the excavation lengthened, the female stayed inside, out of sight, for increasingly longer periods of time. Toward the end of the excavation, she remained inside for periods of 4.5-10 minutes presumably molding a cell at the end of the burrow to hold the paralyzed spider. The female exited her burrow headfirst at 1742, circled twice on the tumulus, re-entered, exited headfirst at 1746, circled, re-entered, exited at 1747, re-entered without circling, and closed herself inside with soil from below. She removed 37 loads of sand from her burrow during the 131 minutes of excavation. Two burrows, excavated by other females at distances of 43 and $54 \mathrm{~cm}$ from this burrow, made it possible to observe 3 wasps simultaneously.

After completion of their burrows, the other 2 females were timed as they left to hunt for spiders and returned to their entrances. They returned without prey on the ground or in flight, usually entered the opening, and exited headfirst from 3 seconds to 2 minutes later. One female returned without prey 9 times, taking 1-38 minutes between consecutive returns. The other female returned without a spider 6 times, taking 2-30 minutes between consecutive returns. Both females departed their open entrances by walking away in large circles or in flights up to $1.3 \mathrm{~m}$ long. 
Once, when returning at nearly the same time and in close proximity, the 2 wasps grappled with one another near an entrance. The second wasp to arrive raised her wings to a nearly vertical position and flew away following the altercation.

Females searched for host spiders in soil crevices, beneath plants and plant litter, inside holes containing funnel-web-weaver and tube-dwelling spider (Agelenidae, Segestriidae) webs, and under fallen tree bark and dried Eucalyptus leaves. One female searched for a spider beneath loose bark 40-80 cm above ground level on a standing Monterey Cypress tree. Another female traveled $3.5 \mathrm{~m}$ during a hunting excursion. Females searching for host spiders ran on the ground, often seemingly randomly following circuitous routes, tapped their antennae on the substrate, and flicked their wings more or less continually.

Prey transport of a paralyzed spider was observed 3 times $(1316,1413,1557$; $23-25^{\circ} \mathrm{C}$ ). Each spider was dragged rapidly backwards on the ground by the wasp. Such a provisioning wasp grasped the base of the spider's hindleg with her mandibles and, held it upright in an almost upright vertical position. Lighter and smaller spiders were dragged more rapidly than heavier and larger spiders. One paralyzed spider was dragged into a wasp's open entrance by its spinnerets, which the female grasped with her mandibles after she had entered the burrow headfirst and turned around inside. Two other spiders were collected from the provisioning females before they entered their burrows.

Only 1 nest was excavated and studied. (The wasp occupant was $9.5 \mathrm{~mm} \mathrm{long).}$ It entered the soil at a roughly $45^{\circ}$ angle with the ground surface. The burrow was $65 \mathrm{~mm}$ long and $41 \mathrm{~mm}$ deep including cell length and depth, respectively. The paralyzed spider was deposited dorsal side upward and face outward in a crude ovoid-shaped cell. The wasp's egg was not found and probably dislodged during removal of the spider from the cell (F.E. Kurczewski, 2014 pers. observ.).

CA: Santa Barbara County, Burton Mesa Ecological Reserve, sandy trail in mixed oak-maritime chaparral habitat; 14 February 2016; A.J. Abela. Host: Alopecosa kochi, adult female, $9.5 \mathrm{~mm}$ (wasp, $10.2 \mathrm{~mm}$ ), with $3^{\text {rd }}$ and $4^{\text {th }}$ left legs cut off at coxa-trochanter joints. The wasp grasped the paralyzed spider by the base of its $3^{\text {rd }}$ right leg with her mandibles and dragged it backwards on the ground (A.J. Abela, 2016 pers. comm.).

CA: Sierra County, Yuba Pass, elevation 2042 m; 5 July 2013; R.E. Coville. Host: Novalena pina Chamberlin \& Ivie (Agelenidae), adult female. The wasp dragged the spider backwards over rocky terrain, grasping the base of its left hindleg with her mandibles and holding the prey in an upright perpendicular position (Fig. 31; R.E. Coville, Richmond, CA, 2013 pers. comm.).

OR: Multnomah County, Portland, Forest Park; 11-12 September 2015; 25-30 ${ }^{\circ} \mathrm{C}$; A. Selzer. Host: Eratigena (formerly Tegenaria) agrestis (Walckenaer) (Agelenidae) (Hobo Spider), adult female, $13 \mathrm{~mm}$; adult male, $12 \mathrm{~mm}$ (wasp, $12.5 \mathrm{~mm}$ ) (A. Selzer, Portland, OR, 2015 pers. comm.).

Arachnospila fumipennis fumipennis (Zetterstedt) (det. M. Buck)

AB, CANADA: Opal Natural Area; 30 August 2012; A. Thysse. Host: ?Alopecosa kochi, adult female. The wasp grasped the spider by a hindleg with her mandibles 
and, holding it ventral side upward or sideways, dragged it backwards across twigs and needles, repositioning her grasp of the leg a few times (Fig. 32; Thysse 2013b; A.Thysse, 2013 pers. comm.).

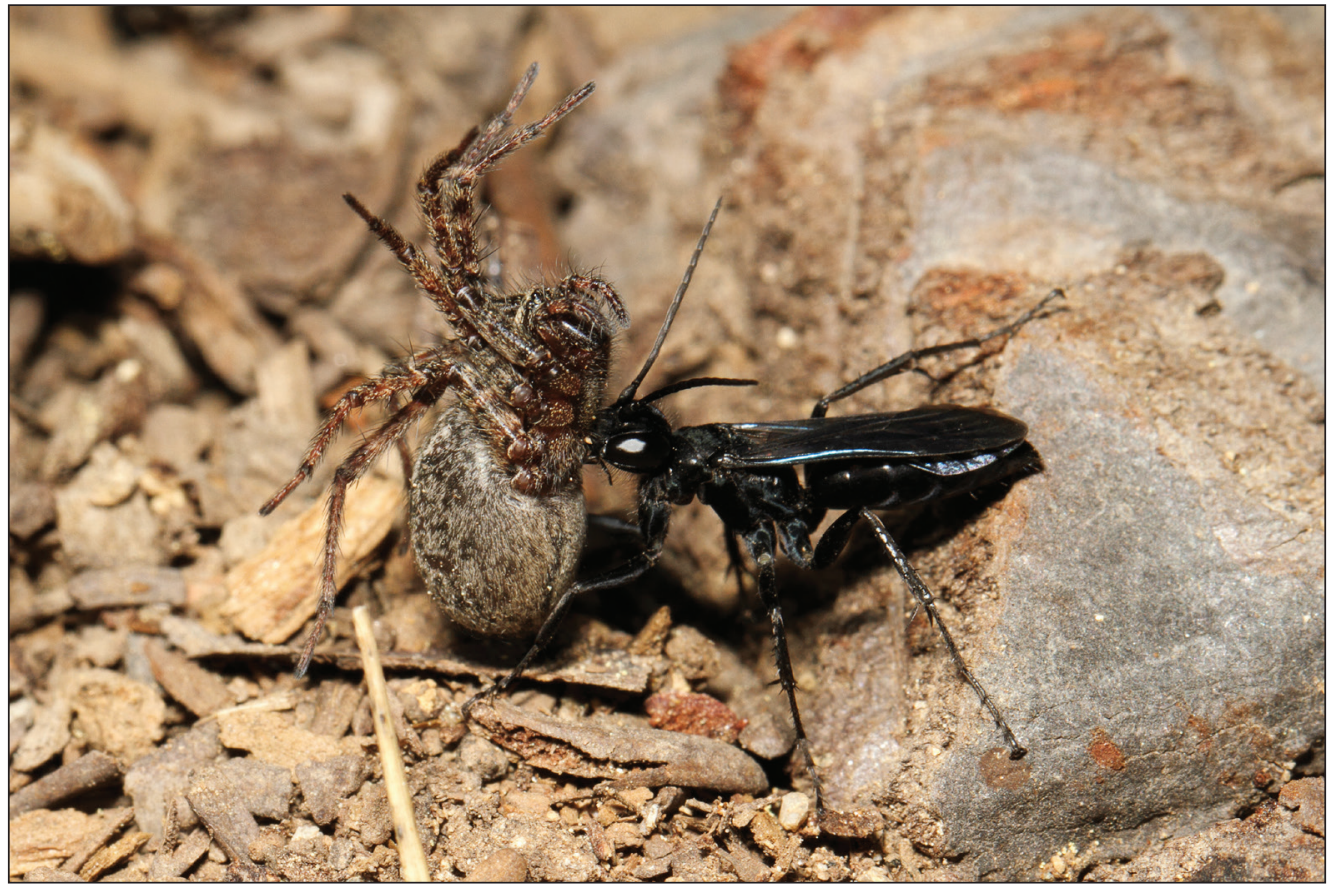

Figure 31. Arachnospila arcta female drags a Novalena pina adult female backwards over rocky terrain, grasping the base of its left hindleg with her mandibles and holding the spider in an upright perpendicular position (R.E. Coville, 2013 pers. comm.).

Figure 32. Arachnospila fumipennis female drags a ?Alopecosa kochi adult female backwards over fallen debris, grasping the spider by a hindleg with her mandibles (A. Thysse, 2013 pers. comm.).

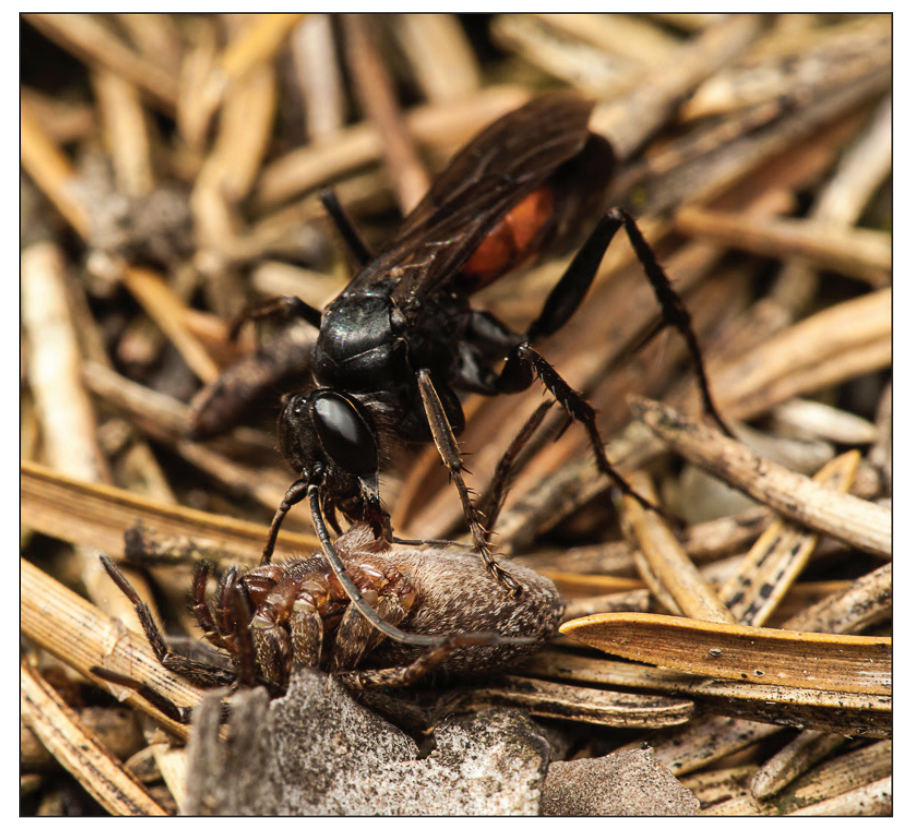




\section{Arachnospila scelesta (Cresson)}

IL: Lake County, Illinois Beach State Park; 22 September 2015; S. Ivanov. Host: Geolycosa wrighti, immature and adult or penultimate female, $16.5 \mathrm{~mm}$ (wasp, 14 $\mathrm{mm}$ ). The wasp first captured an immature $G$. wrighti as it was running across the sand surface. After feeding briefly on the paralyzed immature spider, she abandoned it and walked away to hunt on/in the sand. Ten minutes later this wasp returned to the area of her burrow dragging a much larger, paralyzed adult or penultimate $G$, wrighti across the sand surface (Ivanov 2015).

\section{Aporinellus completus Banks}

TX: Midland County, Midland; 16 June 2013; A. Motsch. Host: Habronattus coecatus (Hentz) species group, possibly H. klauserii (Peckham \& Pekham) (Salticidae), ?adult female. Two equally sized conspecific wasps fought on a woodpile over possession of a small paralyzed salticid, one wasp pulling on the ends of the spider's $3^{\text {rd }}$ and $4^{\text {th }}$ left legs and the other wasp grasping a front right leg (Fig. 33). The victorious wasp with the spider ended up atop leaf litter at the bottom of the woodpile (Fig. 34; Arlon 2013).

Figure 33. Two Aporinellus completus females contest possession of a Habronattus coecatus species group, possibly H. klauseri adult female, both wasps pulling in opposite directions on the spider's legs (A. Motsch [Arlon], 2013 pers. comm.).

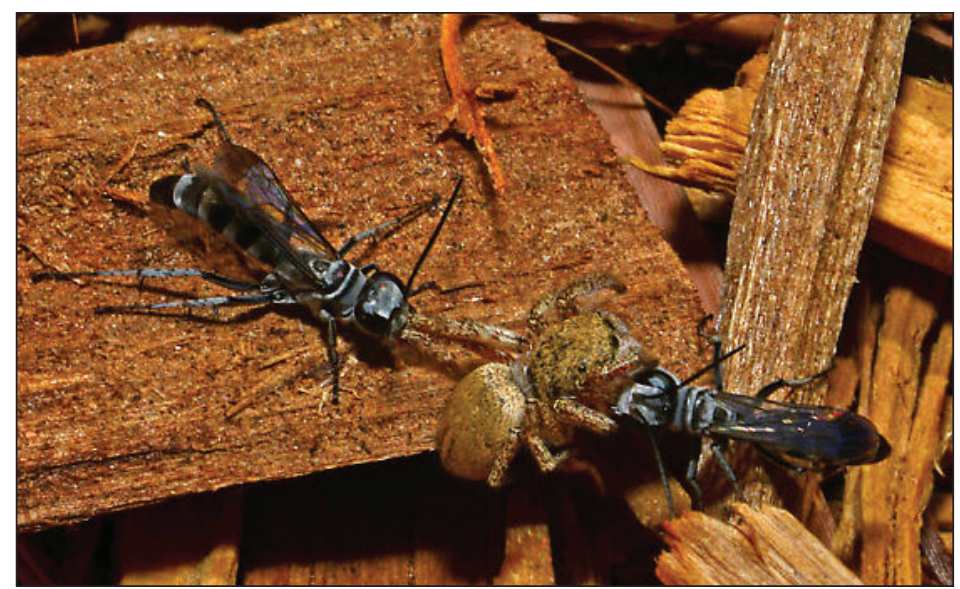

Figure 34. Victorius Aporinellus completus female after gaining sole possession of a Habronattus coecatus species group, possibly $H$. klauseri adult female (A. Motsch [Arlon], 2013 pers. comm.).

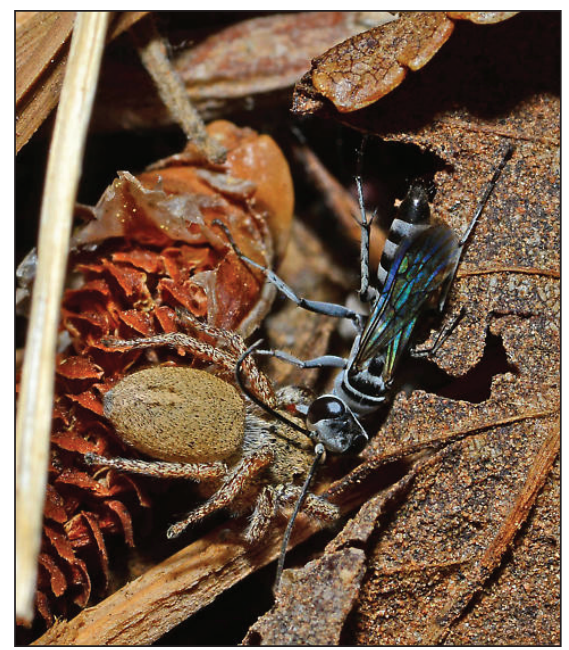


WA: Lincoln County, Coffeepot Lake, US Bureau of Land Management Area; 16 August 16 2015; J. Dammarell. Host: Phidippus sp., either purpuratus Keyserling or purpuratus $\mathrm{x}$ ardens Peckham \& Peckham (Desert Red Jumping Spider) hybrid, penultimate female. The wasp examined the paralyzed spider with her antennae. Then, she grasped it by its lower face or base of chelicerae with her mandibles and dragged it backwards on the ground (Dammarell 2015).

\section{Aporinellus taeniolatus taeniolatus (Dalla Torre)}

CA: San Luis Obispo County, Montana de Oro State Park; 20 August 2014, 1243 (PDT); FEK. Host: Habronattus sp., either californicus (Banks) or peckhami (Banks), penultimate male, $5.5 \mathrm{~mm}$ (wasp, $6.5 \mathrm{~mm}$ ). The provisioning wasp walked backwards, grasping the paralyzed spider by its face with her mandibles while maintaining it dorsal side upward (F.E. Kurczewski, 2014 pers. observ.).

\section{Discussion}

Large spider wasps $(>13 \mathrm{~mm})$ prey on large spiders, moderate-size pompilids $(8-13 \mathrm{~mm})$ on medium-size spiders, and small spider wasps $(<8 \mathrm{~mm})$ on small spiders in an almost straight-line relationship (Kurczewski and Kiernan 2015). Large pompilids capture mainly adult spiders, while small spider wasps catch mostly immature spiders (Kurczewski and Edwards 2012; Kurczewski and Kiernan 2015; Kurczewski and Kurczewski 1968a, 1968b, 1972, 1973). The largest spider wasps capture a high percentage of adult, penultimate, and subadult female spiders, whereas the smallest pompilids provision with a large proportion of immature spiders that haven't reached sexual maturity (Kurczewski and Edwards 2012; Kurczewski and Kiernan 2015; Kurczewski and Kurczewski 1968a, 1968b, 1972, 1973).

Many small and moderate-size pompilids species in the genera Priocnemis, Dipogon, Auplopus, and Anoplius (Pompilinus) are polyphagous in host-spider selection, capturing a wide variety of cursorial-hunting and retreat-dwelling families. Conversely, the largest spider wasps are mainly oligophagous in host-spider selection provisioning with one or a few closely related spider families, usually restricting their captures to burrowing, cursorial-hunting, or orb-weaving types (Kurczewski and Edwards 2012, Kurczewski and Kiernan 2015, this study). The largest spider wasps in the genera and subgenera Pepsis, Entypus, Poecilopompilus, Tachypompilus, and Anoplius (Lophopompilus, Notiochares, Arachnophroctonus, Anoplius s. str.) are unequivocally oligophagous in host-spider selection (Kurczewski and Edwards 2012, Kurczewski and Kiernan 2015, this study). Such a relationship is inexorably connected with the joint seasonal occurrence and correlative large sizes of the spider wasps and their host spiders. Deciduous woodland pompilids with 2 or more generations annually tend to be polyphagous in host-spider selection, while spider wasp species from open areas, abandoned overgrown fields, and woodland borders with only a single generation per year are overwhelmingly oligophagous (Kurczewski and Kiernana 2015). Spider species are more various and numerous in deciduous woodland than in open areas (Kurczewski and Edwards 2012, Kurczewski and Kiernan 2015). 
The spider wasps in this study can arbitrarily be categorized into species that hunt and stock tarantulas (Theraphosidae), folding-door spiders (Antrodiaetidae), and wafer-lid trapdoor spiders (Euctenizidae), often in their own burrows: Pepsis mildei and Pepsis spp., Priocnemis oregona, and Aporus hirsutus, respectively; species that provision their nests with orb-weaving spiders of the families Araneidae and/or Nephilidae: Caliadurgus fasciatellus, Agenioideus humilis, Episyron biguttatus, E. conterminus, E. quinquenotatus, Poecilopompilus algidus, and $P$. interruptus; species that stock their nests predominantly with cursorial-hunting wolf spiders (Lycosidae), fishing spiders (Pisauridae), and other spider families with similar habits: Entypus aratus, E. fulvicornis, E. unifasciatus, Cryptocheilus attenuatus, Phanagenia bombycina, Ageniella accepta, A. conflicta, Tachypompilus ferrugineus, T. unicolor, Anoplius aethiops, A. atrox, A. cleora, A. lepidus, A. americanus, A. apiculatus, A. nigritus, A. semicinctus, A. semirufus, A. fulgidus, A. illinoensis or A. ventralis, A. imbellis, A. ithaca, Ammosphex solonus, Arachnospila fumipennis, and $A$. scelesta; and species that prey on a variety of spiders, especially retreat-dwelling and cursorial-hunting families: Priocnemis minorata, P. cornica, P. germana, P. notha, P. scitula, Dipogon calipterus, D. papago, D. pulchripennis, D. sayi, Auplopus architectus, A. caerulescens, A. carbonarius, A. mellipes, Ageniella arcuata, Agenioideus birkmanni, Sericopompilus apicalis, $S$. neotropicalis, Anoplius marginatus species-complex, A. ?splendens, A. tenebrosus, A. virginiensis, Perissopompilus phoenix, Ammosphex angularis, and Arachnospila arcta. Some pompilid species in this study are highly oligophagous at the family level: Priocnemis nebulosus (Agelenidae), Anoplius carolina (Amaurobiidae), A. depressipes (Pisauridae), Ammosphex michiganensis (Thomisidae), Aporinellus completus, and A. taeniolatus (both Salticidae).

Species of North American Pepsis are parasitoids on large, heavy-bodied, stout-legged spiders belonging to the Infraorder Mygalomorphae (Orthognatha), especially species of Theraphosidae (tarantulas) (Table 1; Kurczewski and Edwards 2012, Kurczewski et al. 2014, Vardy 2000, this study). Species of Pepsis are rather specific as to the particular host genus or species (Hurd 1952, Vardy 2000), and the size (biomass) of the wasp must approximate that of the host spider (Punzo 1994a). For example, several records for orange-winged Pepsis spp. in southern Texas implicate females of species of Aphonopelma (Theraphosidae) as the host genus: A. anax (Kurczewski and Edwards 2012, this study, both as $P$. sp.), A. echina (Chamberlin) (Punzo 1994b, as P. thisbe Lucas), A. ?harlingenum (this study, as $P$. sp.), and $A$. hentzi (this study, as $P$. sp.). Aphonopelma is the only native genus of tarantula in the US (R.C. West, Shaw, BC, Canada, 2016 pers. comm.). Females of Aphonopelma are preferentially captured over males because they have a larger body mass, especially in the abdomen, on which the larval Pepsis can complete development more successfully.

Priocnessus nebulosus is host-specific on funnel-web-weaver spiders of the genus Agelenopsis (Table 1). This pompilid species has been reported to capture both males and females and immature and adult stages of most of the common species of Agelenopsis (Krombein 1979, Kurczewski 2010, Kurczewski and Kiernan 2015, 
F.E. Kurczewski, G.B. Edwards, and J.P. Pitts

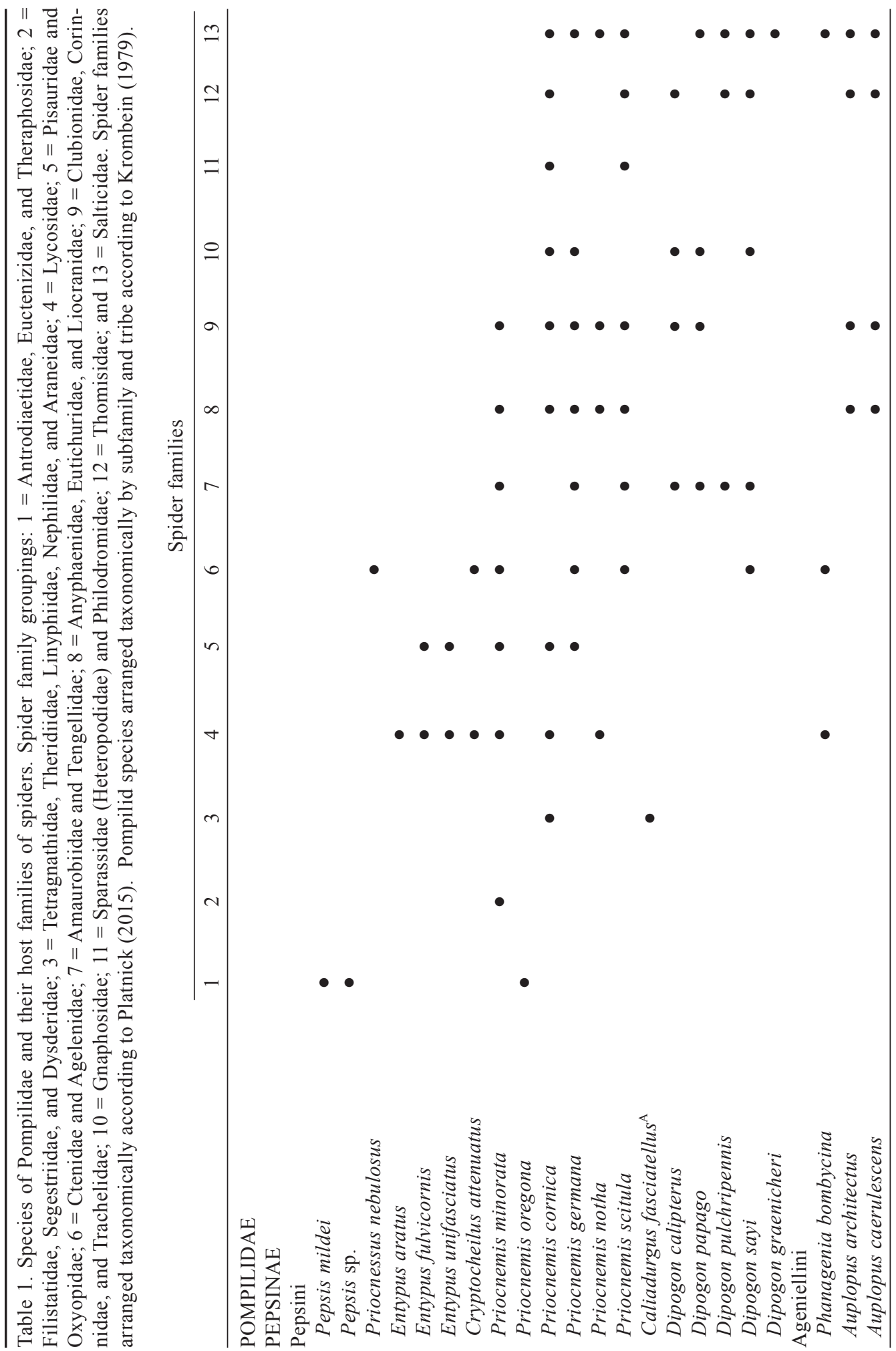




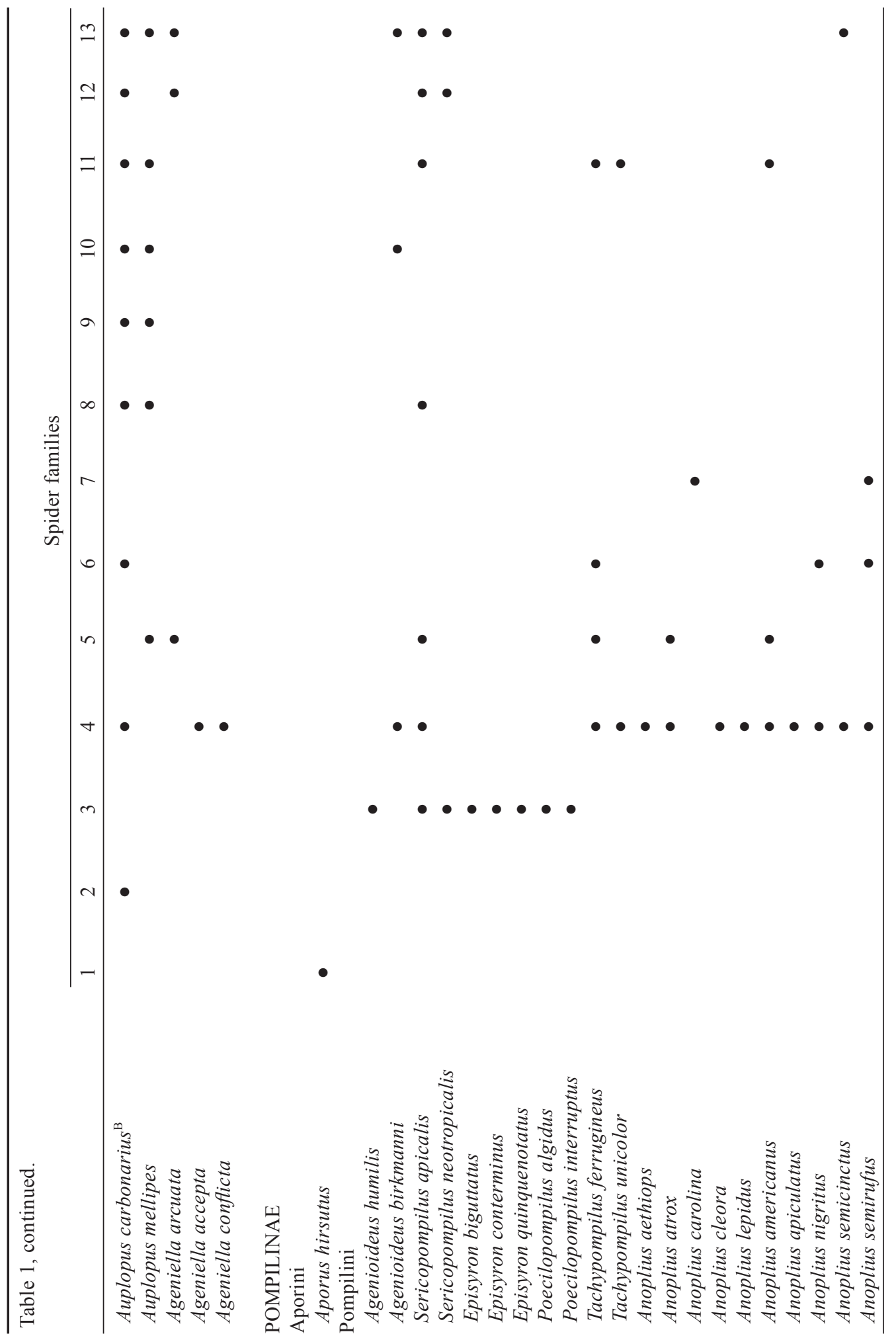


F.E. Kurczewski, G.B. Edwards, and J.P. Pitts

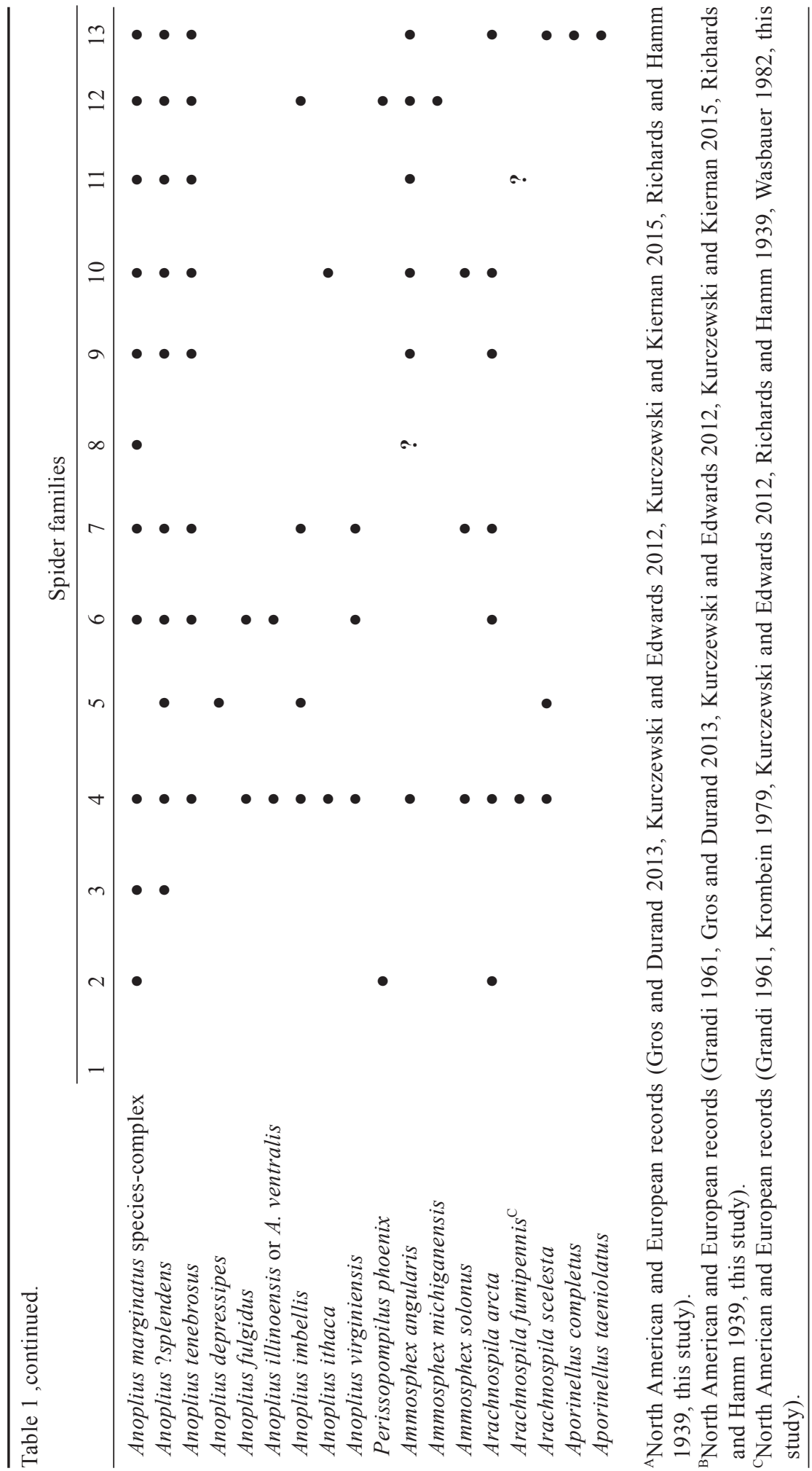


this study). The method of prey transport whereby the wasp straddles the spider ventral side upward, grasps its chelicerae with her mandibles, and walks forward on the ground without amputating its legs at the coxa-trochanter joints is highly unusual in the family Pompilidae (Evans and Yoshimoto 1962).

North American species of Entypus are host-specific predominantly on large adult and subadult female and adult male cursorial-hunting, arboreal, and burrowing spiders belonging to the families Pisauridae and Lycosidae (Table 1; Krombein 1979, Kurczewski and Edwards 2012, Kurczewski and Kiernan 2015, this study). The families Pisauridae (fishing spiders) and Lycosidae (wolf spiders) have somewhat similar taxonomy (Platnick 2015), size (often large), and cursorial predatory habits. These spiders do not build snares, but instead they hunt their prey by running or walking (Kaston 1948). Entypus unifasciatus, reputedly a strict hunter of wolf spiders in North America (Krombein 1979), is now implicated as provisioning additionally with the arboreal fishing spiders Dolomedes albineus and D. tenebrosus (Kurczewski and Edwards 2012, this study). Preferred host-spider genera for E. unifasciatus, aside from Dolomedes (Pisauridae), include Hogna, Rabidosa, especially R. rabida, Tigrosa, and Schizocosa (Lycosidae) (Table 1; Evans and Yoshimoto 1962, Janvier 1930, Krombein 1979, Kurczewski and Edwards 2012, this study). The only 2 host records for E. aratus associate the wolf spider Hogna carolinensis (Kurczewski 1975, this study). In one case, this species used the spider's own burrow for a nest (Kurczewski 1975). Previous E. fulvicornis host records are for Hogna sp. and Schizocosa avida (Walckenaer) (Kurczewski and Edwards 2012, Townes 1957). New host records presented herein for E. fulvicornis add Rabidosa rabida and Dolomedes tenebrosus.

Cryptocheilus attenuatus provisions its nests with spiders belonging to the families Lycosidae (Hogna antelucana, Schizocosa avida, Tigrosa sp. near helluo, Alopecosa aculeata) and Agelenidae (Novalena sp.) (Table 1; Krombein 1979, Wilson and Pitts 2007, this study). Wilson and Pitts (2007) remarked that the behavior required for hunting lycosids, which are vagrant or burrowing, should be different from that required to capture agelenids in their funnel webs. This assumption may not necessarily be true because the agelenid funnel web is not adhesive. Anoplius virginiensis and other pompilid species such as Tachypompilus analis Fabricius were observed to enter funnel webs, walk on the web in pursuit of the agelenid occupant, and pursue the spider as it ran off the web (Barthélémy 2010, Evans and Yoshimoto 1962). Several photographs or descriptions indicate species of Cryptocheilus, including attenuatus, drag the paralyzed spider backwards, dorsal side upward, grasping it by a leg, chelicera, or base of pedipalp (Falk 1997 [photograph by J. Early], Gros and Durand 2013, Harris 1999, Wilson and Pitts 2007, this study).

Priocnemis minorata is strongly polyphagous, having been reported to provision its nests with no less than 8 families of spiders: Dysderidae, Lycosidae, Pisauridae, Agelenidae, Amaurobiidae, Anyphaenidae, Liocranidae, and Clubionidae (Table 1; Kurczewski and Edwards 2012, Kurczewski and Kiernan 2015, this study). The family Philodromidae (Thanatus formicinus [Clerck]) is removed from the list of host spider families of $P$. minorata due to an error in field identification of the wasp 
(F.E. Kurczewski, pers. observ.). Priocnemis oregona, like P. minorata, is a vernal (spring)-nesting species, except it occurs west of the Rocky Mountains and, unlike P. minorata, restricts its host selection to folding-door spiders, especially Antrodiaetidae (Table 1; Krombein 1979, Townes 1957, this study). Priocnemis oregona, like $P$. minorata, makes a multi-celled nest with a single entrance (this study).

Priocnemis cornica is, likewise, strongly polyphagous, reportedly capturing at least 11 families of cursorial-hunting and retreat-dwelling spiders: Linyphiidae, Lycosidae, Oxyopidae, Eutichuridae, Anyphaenidae, Liocranidae, Clubionidae, Trachelidae, Gnaphosidae, Thomisidae, and Salticidae (Table 1; Kurczewski and Edwards 2012, Kurczewski and Kiernan 2015, Wasbauer 1982). In this study, we introduce Philodromidae as a new host family for P. cornica, thereby enlarging the number of host families to 12. Priocnemis germana, P. notha, and P. scitula are also polyphagous in host-spider selection, and thus, polyphagy may be the rule in the subgenus Priocnemis (Kurczewski and Edwards 2012, Kurczewski and Kiernan 2015, this study) (Table 1). Priocnemis germana stocks its nest cells with no less than 8 families of cursorial-hunting and retreat-dwelling spiders: Pisauridae, Agelenidae, Amaurobiidae, Eutichuridae, Anyphaenidae, Gnaphosidae, Clubionidae, and Salticidae (Table 1; Kurczewski and Edwards 2012, Kurczewski and Kiernan 2015, this study). Priocnemis notha, for which we have only a handful of host records, preys on at least 4 families of cursorial-hunting and retreat-dwelling spiders: Lycosidae, Eutichuridae, Clubionidae, and Salticidae, with a preference for small wolf spiders (Lycosidae) (Table 1; Krombein 1979, Kurczewski and Kiernan 2015 , this study). The nesting behavior of $P$. notha is similar to that of $P$. cornica with respect to nesting in bare soil of gardens and waste places and using preexisting burrows (Evans and Yoshimoto 1962). Priocnemis scitula has been reported to stock 8 families of host spiders in its nest cells: Agelenidae, Amaurobiidae, Eutichuridae, Liocranidae, Clubionidae, Philodromidae, Thomisidae, and Salticidae (Table 1; Krombein 1979, Kurczewski and Edwards 2012, Kurczewski and Kiernan 2015, this study).

Caliadurgus fasciatellus is a common Holarctic species that provisions its nests with a wide variety of orb-weaver spiders (Araneidae) in both North America and Europe (Table 1; Gros and Durand 2013, Krombein 1979, Kurczewski and Edwards 2012, Richards and Hamm 1939, this study). In addition, there are 2 host records of this species in Europe provisioning nests with Meta spp. (Tetragnathidae) (Evans and Yoshimoto 1962, Gros and Durand 2013). We add 2 new genera and species of araneids, Larinia directa and Metepeira labyrinthea, to the compilation of North American hosts for this spider wasp species. Caliadurgus fasciatellus is highly unusual among spider wasps in temporarily suspending the paralyzed spider from a plant or other object using the spider's own silken threads while the female wasp excavates her burrow (Evans and Yoshimoto 1962, Kurczewski and Spofford 1985).

Dipogon is a genus of mainly small spider wasps in which many of the species are polyphagous in host selection, preying mostly on small cursorial-hunting and retreat-dwelling spiders: calipterus (Amaurobiidae, Trachelidae, Gnaphosidae, Thomisidae); papago (Amaurobiidae, Clubionidae, Gnaphosidae, Salticidae); 
pulchripennis (Amaurobiidae, Thomisidae, Salticidae); and sayi (Agelenidae, Amaurobiidae, Gnaphosidae, Thomisidae, Salticidae) (Table 1; Krombein 1979, Kurczewski and Edwards 2012, Kurczewski and Kiernan 2015, this study). We introduce the first host record, Anasaitis canosa (Salticidae), for Dipogon g. graenicheri.

Phanagenia bombycina, although appearing to be somewhat polyphagous in host selection based on reported prey families (Lycosidae, Agelenidae, Salticidae), is rather host-specific on species of wolf spiders (Lycosidae) (Table 1; Krombein 1979, Kurczewski and Edwards 2012, Kurczewski and Kiernan 2015, this study). This species and species in the genera Auplopus and (some) Ageniella cut off all or most of the host spider's legs and, sometimes, pedipalps at the coxa-trochanter joints to facilitate prey transport and placement of prey in the limited confines of the cell. In addition, species of Phanagenia and Auplopus construct ovoid or barrelshaped mud cells, often placing several such cells in a concealed and sheltered spot (Krombein 1979, Kurczewski and Edwards 2012, Kurczewski and Kiernan 2015).

Auplopus is a genus of small wasps in which the species are predominantly polyphagous, capturing mainly cursorial-hunting and retreat-dwelling families of spiders: architectus (Eutichuridae, Anyphaenidae, Clubionidae, Trachelidae, Thomisidae, Salticidae); caerulescens (Anyphaenidae, Clubionidae, Trachelidae, Thomisidae, Salticidae); carbonarius (Eutichuridae, Liocranidae, Thomisidae, and Salticidae in North America, 8-12 families in Europe depending on region, with a preponderance of Clubionidae); and mellipes (Pisauridae, Eutichuridae, Anyphaenidae, Clubionidae, Gnaphosidae, Philodromidae, Thomisidae, Salticidae) (Table 1; Gros and Durand 2013, Krombein 1979, Kurczewski and Edwards 2012, Kurczewski and Kiernan 2015, Wasbauer 1982). We present the first host record for A. a. architectus x A. architectus metallicus intergrade (see Townes 1957 for definition of this intergrade).

Ageniella arcuata has been reported to provision its nests with Oxyopidae, Thomisidae, and Salticidae, with most of the records being for adult females of the lynx spider Oxyopes salticus (Table 1; Krombein 1979, Kurczewski and Edwards 2012, this study). Evans and Yoshimoto (1962) noted an A. arcuata transporting an adult female $O$. salticus, with all legs cut off at the coxa-trochanter joints, forward, climbing tall vegetation and making short flights, while straddling the spider and grasping it with the mandibles by its "anterior end". Kurczewski and Edwards (2012) and this study report $A$. arcuata straddling an adult female $O$. salticus, exhibiting the same straddling prey transport behavior but grasping the paralyzed and legless spider with her mandibles at the opposite end of its body (spinnerets).

Nearly a dozen host records for Ageniella (Ageniella) conflicta implicate immature wolf spiders (Lycosidae) in the genera Arctosa, Pardosa, Rabidosa, Trochosa, Varacosa, and ? Hogna as hosts (Table 1; Krombein 1979, Kurczewski and Edwards 2012, Wilson and Pitts 2007), and prompting Wilson and Pitts (2007) to mention that this species is "potentially ... a specialist on lycosids". Our record of ?Arctosa sp. (Lycosidae) for A. conflicta underlines this specificity for wolf spiders (Table 1). Ageniella accepta, although as common as $A$. conflicta in insect collections, pales in comparison to $A$. conflicta with respect to the number of published host 
records. The few host records available for A. accepta also indicate a predilection for immature wolf spiders (Lycosidae) (Table 1). Following amputation of the spider's legs at the coxa-trochanter joints, the paralyzed prey is carried dorsal side upward and face forward, being grasped by a chelicera or pedipalp with the wasp's mandibles (Evans and Yoshimoto 1962, Kurczewski and Edwards 2012, Kurczewski and Kurczewski 1968a, this study [as A. accepta or A. conflicta]). The wasp's wings are held flat on the dorsum and do not assist in the forward transport of the prey. In this study, an A. accepta or A. conflicta periodically released her spider to feed on hemolymph exuding from the point of amputation of one of the spider's legs.

Aporus hirsutus inhabits active and relict sand dunes in the western US, and is especially common in central coastal California. This species hunts, paralyzes, and oviposits on wafer-lid trapdoor spiders of the genus Aptostichus (Euctenizidae) in their own burrows (Table 1), as apparently does the related Aporus (Aporus) luxus (Banks) (Wasbauer 1982). The unusually shaped head and prothorax (for a pompilid) and powerful forelegs of the genus Aporus are probably adaptations for opening and entering the spider's trapdoor and burrow (Krombein 1979, Williams 1928).

Agenioideus (Agenioideus) humilis provisions its nests with species belonging to several genera of orb-weaver spiders (Araneidae): Acacesia, Araneus, Conepeira, Eustala, Larinioides, and Neosconella (Table 1; Krombein 1979, Kurczewski and Edwards 2012, Kurczewski and Kiernan 2015, Wasbauer 1982). We add Neoscona arabesca, $N$. crucifera, and Zygiella x-notata to the known list of A. humilis host genera and species of Araneidae.

Agenioideus (Gymnochares) birkmanni, unlike A. humilis, is somewhat polyphagous in host selection: Schizocosa sp. (Lycosidae) (1 record; Wilson and Pitts 2007); Herpyllus ecclesiasticus as H. vasifer (Walckenaer) (Gnaphosidae) (2 records; Evans 1950, Kurczewski and Kurczewski 1968b); and Platycryptus undatus (Salticidae) (5 records; Kurczewski and Spofford 1986, this study; Table 1). Most of the observations on this species were made near woodland, and several sightings involved the wasp pulling the spider backwards up a vertical or across a horizontal surface, e.g., tree or wooden object, and grasping it by a foreleg or chelicera with the mandibles. In one case, the right $1^{\text {st }}$ and $2^{\text {nd }}$ legs of the spider were missing and perhaps purposely cut off or accidentally broken off by the wasp (Wilson and Pitts 2007).

Sericopompilus apicalis is strongly polyphagous in host selection, provisioning nests with spiders belonging to the families Araneidae, Lycosidae, Oxyopidae, Anyphaenidae, Philodromidae, Thomisidae, and Salticidae (Table 1; Krombein 1979, Kurczewski 1981, Kurczewski and Edwards 2012, this study). Although not nearly as well studied ( 3 host records), S. neotropicalis is also polyphagous in host selection having been reported to provision its nests with the families Theridiidae (Latrodectus mactans (Fabricius) [Black Widow Spider]), Thomisidae, and Salticidae (Table 1; Kurczewski and Edwards 2012, Wasbauer 1982, this study).

North American species of Episyron hunt, capture, and provision their nests exclusively with genera of orb-weaving Araneidae: E. biguttatus uses Acanthepeira, 
Araneus, Argiope, Eriophora, Eustala, Larinioides, Metepeira, and Neoscona; E. conterminus uses Acacesia, Araneus, Argiope, Eriophora, Eustala, Gea, Larinia, Neoscona, and Neosconella; and E. quinquenotatus uses Acanthepeira, Araneus, Araniella, Argiope, Cyclosa, Eustala, Larinioides, Metepeira, Neoscona, Singa, and Zygiella (Table 1; Krombein 1979, Krombein and Norden 1996, Kurczewski 1981, Kurczewski and Edwards 2012, Kurczewski and Kiernan 2015, Kurczewski and Spofford 1986, Wasbauer 1982, this study). Episyron biguttatus and E. quinquenotatus provision with 7 host genera of Araneidae in common in the northeastern US despite often occurring in different natural communities (F.E. Kurczewski, pers. observ.; Kurczewski and Kiernan 2015). We present the first host record for Episyron quinquenotatus hurdi x E. q. quinquenotatus intergrade (see Evans 1950 for definition of this intergrade).

Poecilopompilus algidus provisions its nests with adult and subadult female orb-weaver spiders of the families Araneidae and Nephilidae, while P. interruptus stocks its nests mainly with adult and subadult female orb-weavers of the family Araneidae (Table 1). The 2 species of Poecilopompilus provision with 4 host genera of Araneidae in common: Araneus, Argiope, Eriophora, and Neoscona (Krombein 1979, Kurczewski and Edwards 2012, Martins 1991, this study).

Tachypompilus ferrugineus provisions its nests with large, often adult, female Lycosidae, Pisauridae, Sparassidae (Florida), and Ctenidae (Costa Rica), stocking a preponderance of wolf spiders (Lycosidae) and fishing spiders (Pisauridae) in central and eastern North America (Table 1; Krombein 1979; Kurczewski 1981, 1989, 2010; Kurczewski and Edwards 2012; Kurczewski and Kiernan 2015; Wasbauer 1982; Wilson and Pitts 2007; this study). Adult females of Rabidosa rabida and Tigrosa helluo, both Lycosidae, are commonly captured host species, sex, and stage in the eastern and midwestern US. We present herein a new family (Sparassidae, Heteropoda venatoria) and new genus and species of host spider, Schizocosa avida, for T. ferrugineus. The new family record for $T$. ferrugineus (Sparassidae [huntsman or giantcrab spiders]) coincides with other species of Tachypompilus that include Sparassidae in their host-spider family repertoire: T. unicolor, T. analis, T. erubescens (Taschenburg), and T. ignitus (Smith) (Barthélémy 2010; Iwata 1942, 1964, 1976; Gess and Gess 1980; Krombein 1991; Kurczewski and Edwards 2012; Martins 1991; Nakao and Iwata 1964; Williams 1919). Tachypompilus unicolor has similar nesting behavior and host preferences as T. ferrugineus, its host-spider families include large adult and subadult Lycosidae and Sparassidae in the western US (Table 1; Krombein 1979, Kurczewski and Edwards 2012, this study). The host-spider families for both T. ferrugineus and T. unicolor include genera and species that are rather large in size and vagrant and cursorial-hunting in habitat and behavior.

Anoplius aethiops provisions its nests with large, often adult female Lycosidae, especially species of Hogna and Tigrosa (Table 1; Krombein 1979, Kurczewski and Edwards 2012, Kurczewski and Kiernan 2015, this study). Tigrosa helluo is a frequent host species for $A$. aethiops in the northeastern US (Kurczewski and Edwards 2012, Kurczewski and Kurczewski 1968a, this study). We introduce 
Rabidosa punctulata as a new host genus and species for A. aethiops in the midwestern US. Anoplius atrox, which occurs in some of the same natural communities as $A$. aethiops, also provisions its nests with large, often adult, female Lycosidae and, in addition, captures large, often adult, female Dolomedes (Pisauridae) (Table 1; Krombein 1979, Kurczewski and Edwards 2012, Kurczewski and Kiernan 2015, this study). Anoplius cleora, another species in the subgenus Lophopompilus, is basically host-specific on adults and subadults of both sexes of Arctosa littoralis (Lycosidae), capturing mainly immatures/juveniles in early summer and adult females in late summer and early fall (Table 1; Kurczewski and Kiernan 2015, this study). Unlike $A$. aethiops and $A$. atrox, which occur in abandoned overgrown fields, woodland edges, meadows, and prairies, A. cleora inhabits bare sandy soils, often on beaches near water courses (Evans and Yoshimoto 1962, Kurczewski and Kiernan 2015, this study). Anoplius carolina, also in the subgenus Lophopompilus, is smaller than the aforementioned species, inhabits woodland instead of open areas, and is host-specific on moderate-size hacklemesh-weaver spiders (Amaurobiidae) (Table 1; Krombein 1979, this study).

Anoplius lepidus captures and stocks wolf spiders of the family Lycosidae in its nest-cells. Several of the host records in the central and southeastern US are for Rabidosa punctulata and R. rabida (Evans and Yoshimoto 1962, Krombein 1979, Kurczewski and Edwards 2012, this study).

Anoplius americanus provisions its nests almost exclusively with wolf spiders (Lycosidae), whereas A. nigritus captures a preponderance of Lycosidae and, occasionally, Agelenidae (funnel-web-weaver spiders) (Table 1; Krombein 1979, Kurczewski and Edwards 2012, Kurczewski and Kiernan 2015, this study). Anoplius semicinctus is similar to A. nigritus in its host-spider preference, selecting predominantly wolf spiders of the family Lycosidae (Gwynne 1979, Krombein 1979, Kurczewski and Edwards 2012, Kurczewski and Kiernan 2015, Kurczewski et al. 1987). Anoplius apiculatus, like A. cleora, is host-specific on Arctosa littoralis (Lycosidae), albeit almost always provisioning with immature or juvenile spiders instead of adults or subadults (Table 1; Krombein 1979, Kurczewski and Kiernan 2015, this study). Anoplius semirufus hunts and captures predominantly moderate-size wolf spiders (Lycosidae), but also stocks in its nests Agelenidae and, rarely, Amaurobiidae (Table 1, Krombein 1979, Kurczewski and Edwards 2012, Kurczewski and Kiernan 2015).

Anoplius marginatus species-complex, A. ?splendens, and A. tenebrosus are strongly polyphagous species in the subgenus Pompilinus, having been reported to capture at least 12,10, and 8 families of spiders, respectively, in North America (Table 1; Alm and Kurczewski 1984, Krombein 1979, Kurczewski and Edwards 2012, Kurczewski and Kiernan 2015, Wasbauer 1982, this study). Anoplius tenebrosus is highly unusual among North American spider wasps in the subfamily Pompilinae in that the females overwinter in deep underground burrows in the northeastern US and southeastern Canada in the early fall, re-emerge from the burrows during the first warm days of spring, hunt and capture spiders, and provision their nests before most other pompilid species emerge (Alm and Kurczewski 1984). 
Anoplius depressipes is host-specific on large fishing or nursery-web spiders (Pisauridae) in the vicinity of standing water such as swamps, ponds, lagoons, and slow-moving streams or on arboreal and terrestrial fishing spiders in moist woodland (Table 1; Evans and Yoshimoto 1962, Krombein 1979, Kurczewski and Edwards 2012, Kurczewski and Kiernan 2015, this study). Host spiders of A. depressipes usually comprise adult or subadult females of the genus Dolomedes. In this study, we introduce Pisaurina mira as a new host genus and species. Females of $A$. depressipes are structurally and ecologically adapted for running across the water surface, diving below the surface in search and pursuit of fishing spiders, and towing the paralyzed host spider across the water surface, using the wings, to a preexisting burrow on the shore (Evans and Yoshimoto 1962, Krombein 1979, Kurczewski and Edwards 2012, Kurczewski and Kiernan 2015, Roble 1985, this study).

Anoplius fulgidus is a tropical species that inhabits extreme southern sections of the US (Evans 1951a). Only a pair of host records have previously been reported for this little-studied species, Pirata ?sedentarius Montgomery and Arctosa sp. near littoralis, both genera belonging to the family Lycosidae (Table 1; Krombein 1979). Pirata?sedentarius may have been used only for adult feeding (Wasbauer 1955, Wasbauer and Kimsey 1985). We herein record Rabidosa punctulata, another lycosid, and Hololena ?curta (Agelenidae), a new family, genus and species, as prey of A. fulgidus in the southwestern US.

Anoplius illinoensis closely resembles A. ventralis in size, external morphology, color, geographic range, seasonal occurrence, habitat, and size and type of host spider (Evans 1951a, Evans and Yoshimoto 1962, Krombein 1979, Kurczewski 1989, Kurczewski and Kiernan 2015). Both species apparently use preexisting openings in the ground for nesting, as do many other species of Anoplius s. str. (Evans and Yoshimoto 1962, Richards and Hamm 1939, this study). Anoplius illinoensis and A. ventralis often capture the same species of wolf spider (Lycosidae) (Kurczewski and Kiernan 2015, this study). In addition, A. ventralis stocks Agelenopsis spp. (Agelenidae) in its nests (Krombein 1979, Kurczewski and Kiernan 2015, this study).

Anoplius imbellis predominantly captures and stocks small and moderate-size wolf spiders (Lycosidae) in its nests (Krombein 1979), but recent studies extend its host selection to also include the families Pisauridae, Amaurobiidae, and Thomisidae (Table 1; Kurczewski and Edwards 2012, Kurczewski and Kiernan 2015, Wasbauer 1982, Wilson and Pitts 2007, this study). The use of preexisting depressions, excavation of burrows from the ground surface, and multi-celled nests with consecutively made cells in close proximity further characterize the nesting behavior of this species (Kurczewski and Edwards 2012, this study).

Anoplius ithaca is a specialist on small wolf spiders (Lycosidae), especially in the genus Pardosa, although there is 1 record of this pompilid species capturing Gnaphosidae (Krombein 1979, Kurczewski and Kiernan 2015, Kurczewski et al. 1987, Wasbauer 1982). Anoplius ithaca occurs mainly along rocky stream beds (Evans 1951a, Evans and Yoshimoto 1962, Wasbauer 1957), but occasionally this species nests in sandy beaches that lack stones and pebbles (Evans and Yoshimoto 
1962, Kurczewski and Kiernan 2015). The tarsal claws of this species are large, bifid, and asymmetrical, with the inner claw being distinctly longer than the outer claw-evidently an adaptation for the stone-loving habits of this wasp species (Evans 1951a).

Anoplius virginiensis is a common inhabitant of deciduous forests in the northeastern US and southeastern Canada, being found in woodland openings where there are stumps and fallen timber (Evans and Yoshimoto 1962). This species nests in preexisting galleries in dead wood (Evans and Yoshimoto 1962). Anoplius virginiensis is moderately polyphagous, provisioning its nests with moderate-size host spiders belonging to the families Lycosidae, Agelenidae, and Amaurobiidae (Table 1; Krombein 1979, Kurczewski 2010, Kurczewski and Kiernan 2015, this study).

Our record of Perissopompilus phoenix preying on Xysticus sp. (Thomisidae) is only the $2^{\text {nd }}$ host-spider record for this uncommon species of Pompilidae. Evans (1966) reported this species of spider wasp capturing Filistata sp. (Filistatidae) in Riverside County, CA. In both observations of host-spider transport, the wasp dragged the paralyzed spider backwards on sparsely vegetated ground, grasping a leg with the mandibles.

Ammosphex angularis is strongly polyphagous, having been reported to provision its nests with Lycosidae, ?Anyphaenidae, Clubionidae, Corinnidae, Gnaphosidae, Philodromidae, Thomisidae, and Salticidae throughout North America (Table 1; Krombein 1979, Kurczewski and Edwards 2012, Kurczewski and Kiernan 2015, this study). Ammosphex michiganensis is highly specific in host selection, all records for this species being for the crab spider genus Xysticus (Thomisidae) (Table 1). In other aspects of nesting behavior, this species is typically pompiline in excavating its own burrow after capturing and paralyzing the host spider, stashing the spider in a concealed place, usually above ground, during burrow excavation, dragging the spider backwards by the base of a leg while holding it in a nearly upright perpendicular position, pulling the spider into the burrow by its spinnerets with the mandibles, and laying an egg on the paralyzed prey's abdomen (Krombein 1979, Kurczewski and Snyder 1964). Ammosphex solonus provisions its nests predominantly with wolf spiders (Lycosidae) and, rarely, Gnaphosidae (Krombein 1979, Kurczewski and Edwards 2012). In this study, we introduce Tengellidae as a new host family for $A$. solonus.

Arachnospila arcta is strongly polyphagous, having been reported to provision its nests with cursorial-hunting and retreat-dwelling spiders belonging to the families Segestriidae, Lycosidae, Agelenidae, Amaurobiidae, Clubionidae, Gnaphosidae, and Salticidae (Table 1; Krombein 1979, Kurczewski and Edwards 2012, Kurczewski and Kiernan 2015, Wasbauer 1982, this study). All A. arcta host records in this study are for tube-dwelling Segestriidae or funnel-web-weaving Agelenidae, supporting our observation of the wasps searching for prey in tubular silken retreats or on flat silk sheets leading to such retreats. Females of $A$. arcta, unlike many other pompiline species, excavate the provisioning burrow before capturing and transporting the spider to the nest (Evans 1951b, Evans and Yoshimoto 1962, this study). Arachnospila fumipennis, in contrast to A. arcta, is highly 
oligophagous in host selection in North America, provisioning its nest cells only with wolf spiders (Lycosidae) (Table 1; Krombein 1979, Kurczewski and Edwards 2012, Wasbauer 1982, this study). Arachnospila scelesta is predominantly a hunter of wolf spiders (Lycosidae), although it has been reported to rarely capture fishing spiders (Pisauridae) and large jumping spiders (Salticidae) (Gwynne 1979, Krombein 1979, Kurczewski 2010, Kurczewski and Kiernan 2015, Kurczewski et al. 1987, Wasbauer 1982). In the case of burrowing Geolycosa wolf spiders, and unlike the pompilids Anoplius nigritus and A. semicinctus, Arachnospila scelesta females do not use the spider's burrow for a nest but, instead, dig their own burrow within the sand (Gwynne 1979, Kurczewski and Kiernan 2015, Kurczewski and Kurczewski 1973, McQueen 1978).

The North American species of Aporinellus are among the smallest of spider wasps and their host spiders are mostly tiny compared to prey of other Nearctic Pompilidae. Aporinellus taeniolatus hunts, captures, and stocks species of jumping spiders (Salticidae) in its nest-cells (Table 1; Krombein 1979, Kurczewski and Edwards 2012, Kurczewski and Kiernan 2015, Kurczewski et al. 1988, this study). Aporinellus completus, like A. taeniolatus, is host-specific on Salticidae (Table 1; Krombein 1979, Kurczewski and Kiernan 2015, Wasbauer 1982, this study).

\section{Acknowledgments}

We thank Matthias Buck for the identification of some spider wasp species and Robb Bennett, David Bixler, Kelly Kissane, Joe Lapp, Robin Leech, Laura Paxson, Darrell Ubick, Rick West, and Chao Lun Wu for naming a number of spider genera and species. Keith E. Kurczewski, son of the first author, assisted with field collections and observations in central coastal California. David Keil identified the California coastal dune scrub plant community and other California plant species. We are indebted to the following individuals for their field observations, online descriptions, telephone and email information, and photographs used and not used in this monograph: Alice J. Abela, Yurika Alexander, Joshua P. Allen, Ralph Arveson, Peter Assmann, Seth J. Ausubel, John and Jane Balaban, Carl D. Barrentine, Kyron Basu, Andrew Bateman, David Brady, Val Bugh, Carmen C. Champagne, Jesse Christopherson, Linda F. Cooper, M. R. Corder, Patrick Cotinis, Rollin E. Coville, Shelly Cox, Stephen Creswell, D. Crispin, Peter Cristophono, Rob Curtis, Jeanne Dammarell, Dandybiologist, Even Dankowicz, Owen Davids (Hobo Joe A.K.A. Insect Lover), Tony DiTerlizzi, Drakken, Eaglebeach, Jeremy Early, Eric R. Eaton, Charles Eiseman, Noah Elhardt, S.J. Falk, Robert Ganz, G.K. Gerber, Sharon E. Ginsburg, J. Gluth, H. Go, Amy Goodman, Jay Greenberg, Jason Griffin, Joyce Gross, Patricia Hankey, George Val Hart, Ron Hemberger, Sam Houston, Wayne Hughes, Phil Huntley-Franck, Jonas Insinga, Eric Isley, Stoil Ivanov, S.R. Johnson, Gordon Johnston, KC Wildlife, Rich Kelly, Gary Kessler, Tom Klein, Josh D. Kouri, John Lampkin, Greg Lasley, Darrah J.G. Leffler (WanderingMogwai), Paul A. Lenhart, LilWeezyAnna, Miller and Stephanie MacDerment, Arthur Scott Macmillan, Martin-Hall, Mayfly 1963, M.D. McIvor, Stan McKechnie, Natalie McNear, Charles W. Melton, Colette Micallef, Eileen Miller, Philippe Moniotte, Graham Montgomery, Mark Moran, Racquel Morris, Arlon Motsch (Arlon), Patrick Murray, Tom Murray, Naturenut, Nick, Loren and Babs Padelford, Dale and Elva Paulson, Julia Pearson, Shelley Penner, Rob Ransom, Bryan E. Reynolds, Donald R. Riley, Shannon Schade, Paul A. Scharf, Marie L. Schmidt, Ken Schneider, Aaron Schusteff, T. Scrider, Adam Selzer, James Shelton, Charles Sheppard, Judith Lopez Sikora (Taogirl), Sipolandis, John M. Smith, Naomi Smith, Rick 
Snider, R.J. Speer, Mark Swanson, Adrian Thysse, Edward Trammel, Tim Turner, Royal M. Tyler Jr., John VanDyk, Tracy Palmer Villalobos, Richard K. Walton, Melvin Wei, Sally L. White, James Williamson, Cathy Wilson, Herb Wilson, and Bo Zaremba. John VanDyk, Publisher and Editor of BugGuide, was instrumental in serving as liaison between the first author and persons who submitted photographs and descriptions of spider wasp-spider encounters to BugGuide. Charles W. Melton, Rob Ransom, Bryan E. Reynolds, and Tiffany Yau enlarged photographs of specific wasp body parts that enabled the identifications of Auplopus carbonarius, A. mellipes variitarsatus, Anoplius lepidus atramentarius, and A. fulgidus. Joseph W. Stoll reconfigured the front and back cover photographs. Diane H. Kiernan ran a 2 sample $t$-test of head measurements for Auplopus carbonarius versus $A$. mellipes variitarsatus. Tsutomu Nakastugawa translated papers written in Japanese. Keith Goldfarb assisted with manuscript editing, formatting, photograph selection, and cover photograph composition. We thank Joseph S. Wilson (Utah State University) for serving as Guest Editor. This research was supported by the Utah Agricultural Experiment Station, Utah State University, and approved as journal paper number 8948.

\section{Literature Cited}

Abela, A. (aliceinwll's photostream). 2013. Tarantula hawk (Pepsis sp.) with wolf. Available online at http://www.flickr.com/photos/44150996@NO6/9456839406/in/photostream/. Accessed 23 November 2013.

Abela, A. (aliceinwll's photostream). 2015a. Spider wasp with prey (Aporus). Available online at https://www.flickr.com/photos/44150996@16773609160/in/photostream/.Accessed 12 April 2015.

Abela, A. (aliceinwll's photostream). 2015b. Aporus hirsutus with Southern Coastal Dune Trapdoor Spider (Aptostichus simus). Available online at https://www.flickr.com/photos/44150996@NO6/18883781756/in/photostream/. Accessed 18 June 2015.

Abela, A. 2016a. Perissopompilus phoenix - female. Available online at http://www.bugguide.net/node/view/1288992/bgimage. Accessed 7 September 2016.

Abela, A. (aliceinwll's photostream). 2016b. Spider wasp (Perissopompilus phoenix) with prey. Available online at https://www.flickr.com/photos/44150996@N06/28844567313. Accessed 7 September 2016.

Alexander, Y. 2010. Spider wasp and prey - Caliadurgus fasciatellus. Available online at http://www.bugguide.net/node/view/458402/bgimage. Accessed 10 July 2015.

Alexander, Y. 2014. Black and orange spider wasp - Ageniella. Available online at http:// www.bugguide.net/node/view/945997/bgimage. Accessed 3 August 2014.

Allen, J.P. 2014. Wasp with spider - Cryptocheilus attenuatum - female. Available online at http://www.bugguide.net/node/view/968181/bgimage. Accessed 2 August 2014.

Alm, S.R., and F.E. Kurczewski. 1984. Ethology of Anoplius tenebrosus (Cresson) (Hymenoptera: Pompilidae). Proceedings of the Entomological Society of Washington 86:110-119.

Arlon (Arlon Motsch). 2013. Tiny wasp with prey - Aporinellus. Available online at http:// www.bugguide.net/node/view/787291. Accessed 10 July 2015.

Arvesen, R. 2013. Spider hunter wasp (Tachysphex ferrugineus) dragging paralyzed wolf spider. Available online at http://www.flickr.com/photos/9139233144/in/photostream/. Accessed 27 July 2014.

Assmann, P. 2012. Plano Outdoor Learning Center/Bob Woodruff Park/Oak Point Nature Preserve. July 1, 2012. Spider wasp (Entypus fulvicornis) with paralyzed prey (wolf spider, Lycosidae). Available online at http://www.utdallas.edu/ assmann/POLC/ polc_070112.html. Accessed 17 July 2014. 
Ausubel, S.J. 2016. Priocnemis hestia (?) with Xysticus sp. prey. Available online at http:// www.bugguide.net/node/view/1280195/bgimage. Accessed 26 August 2016.

Balaban, J., and J. Balaban. 2012. Wasp with nursery web spider - female. Available online at http://www.bugguide.net/node/view/701177. Accessed 29 July 2015.

Barrentine, C.D. 2012. Pompilidae - Auplopus? Available online at http://www.bugguide. net/node/view/651077/bgimage. Accessed 28 October 2014.

Basu, K. 2013. Wasp with prey - Auplopus architectus. Available online at http://www.bugguide.net/node/view/831083. Accessed 18 July 2014.

Bateman, A. 2007. Small black wasp with spider. Available online at http://www.bugguide. net/node/view/133812. Accessed 19 September 2014.

Barthélémy, C. 2010. Preliminary description of the predatory and nesting behavior of Tachypompilus analis (Pompilidae: Pompilinae) in Hong Kong, China. Hong Kong Entomological Bulletin 4:3-9.

Brady, D. 2010. Spider wasp - Episyron - female. Available online at http://www.bugguide. net/node/view/439300/bgimage. Accessed 10 July 2015.

Buck, M. 2005. Two introduced spider wasps (Hymenptera: Pompilidae) new to Canada, with notes on nesting habits and the incidence of introduction. Canadian Entomologist 137:278-282.

Bugh, V. 2010. The Lady Bird Johnson Wildflower Center. The Fauna Project. Survey August 21, 2010 (spider wasp with Arizona jumper; spider wasp with barn spider). Available online at http://www.austinbug.com/survey/2010/survey8-21-2010.html. Accessed 2 October 2013.

Champagne, C.C. 2010. Spider wasp - female. Available online at http://www.bugguide.net/ node/view/457253/bgimage. Accessed 21 October 2014.

Christopherson, J. 2015. Wasp with spider prey. Available online at http://www.bugguide. net/node/view/1083475/bgimage. Accessed 24 July 2015.

Corder, M.R. 2009. Pepsis and prey. Available online at http://www.flickr.com/photos/34249425@N03/3870964360. Accessed 29 November 2013.

Cotinis, P. 2014. Phanagenia bombycina - female. Available online at http://www.bugguide.net/node/view/987350/bgimage. Accessed 28 July 2015.

Cox, S. 2014. Spider hunter. Available online at http://www.bugguide.net/node/ view/1007596/bgimage. Accessed 16 November 2014.

Creswell, S. 2010. Pompilidae with spider - female. Available online at http://www.bugguide.net/node/view/871117/bgimage. Accessed 5 August 2014.

Creswell, S. 2012a. Spider wasp, early spring hunter - Priocnessus minorata. Available online at http://www.bugguide.net/node/view/630357/bgimage. Accessed 10 October 2013.

Creswell, S. 2012b. Spider wasp dragging prey - Anoplius - female. Available online at http:// www.bugguide.net/node/view/635820, 635821/bgimage. Accessed 23 October 2014.

Crispin, D. 2007. Wasp with tarantula - Pepsis. Available online at http://www.bugguide. net/node/view/156506/bgimage. Accessed 25 July 2015.

Cristophono, P. 2013. Wasp battles spider? Available online at http://www.bugguide.net/ node/view/852823/bgimage. Accessed 14 October 2015.

Curtis, R. 2006. 6007845 Pompilid - Anoplius - female. Available online at http://www. bugguide.net/node/view/66801/bgimage. Accessed 29 September 2013.

Curtis, R. 2016. 3013780 pomp - female. Available online at http://www.bugguide.net/ node/view/1251276/bgimage. Accessed 8 August 2016.

Dammarell, J. 2015. Gray and black spider wasp. Available online at http://www.bugguide. net/node/view/1123314/bgimage. Accessed 20 August 2015.

Dandybiologist. 2015. Red-tailed Spider Hunter (Tachypompilus ferrugineus). Available online at https://www.inaturalist.org/observations/1834246. Accessed 21 August 2016. 
Dankowicz, E. 2013. Spider wasp and spider. Available online at http://www.bugguide.net/ node/view/877956/bgimage. Accessed 2 August 2014.

Dankowicz, E. 2015a. Pompilidae. Available online at http://www.bugguide.net/node/ view/1161802/bgimage. Accessed 3 November 2015.

Dankowicz, E. 2015b. Pompilidae. Available online at http://www.bugguide.net/node/ view/1161804/bgimage. Accessed 3 November 2015.

DiTerlizzi, T. 2004. Spider wasp with prey. Available online at http://www.bugguide.net/ node/view/13322/bgimage. Accessed 20 September 2014.

Drakken. 2006. Wasp and spider - Tachypompilus ferrugineus. Available online at http:// www.bugguide.net/node/view/73983/bgimage. Re-accessed 8 August 2014.

Eaglebeach. 2015. Spider wasp. Available online at http://www.bugguide.net/node/ view/1099893/bgimage. Accessed 24 July 2015.

Eaton, E.R. 2012a. Wasp Wednesday: Ageniella accepta/conflicta. Available online at http://www.bugeric.blogspot.com/2012/08/wasp-wednesday.ageniella.html. Accessed 10 October 2013.

Eaton, E.R. 2012b Wasp Wednesday: Anoplius aethiops. Available online at http://www. bugeric.blogspot.com/2012/10/wasp-wednesday-anoplius-aethiops.html. Accessed 17 October 2013.

Eaton, E.R. 2015. Spider wasp with prey - Agenioideus humilis - female. Available online at: http://www.bugguide.net/node/view/1092108/bgimage. Accessed 11 July 2015.

Eiseman, C. 2004. Spider wasp with prey - female. Available online at http://www.bugguide.net/node/view/355078/bgimage. Accessed 20 November 2014.

Eiseman, C. 2011. Spider wasp - Anoplius. Available online at http://www.bugguide.net/ node/view/615172/bgimage. Accessed 19 November 2014.

Elhardt, N. 2012. Tachypompilus with unknown spider - Tachypompilus ferrugineus - female. Available online at http://bugguide.net/node/view/697784/bgimage. Accessed 27 November 2013.

Evans, H.E. 1950. A taxonomic study of the Nearctic spider wasps belonging to the tribe Pompilini (Hymenoptera: Pompilidae). Part I. Transactions of the American Entomological Society $75: 133-270$.

Evans, H.E. 1951a. A taxonomic study of the Nearctic spider wasps belonging to the tribe Pompilini (Hymenoptera: Pompilidae). Part II: Genus Anoplius Dufour. Transactions of the American Entomological Society 76:207-361.

Evans, H.E. 1951b. A taxonomic study of the Nearctic spider wasps belonging to the tribe Pompilini (Hymenoptera: Pompilidae). Part III. Transactions of the American Entomological Society 77:203-330.

Evans, H.E. 1966. Some unusual prey records for Pompilidae. Proceedings of the Entomological Society of Washington 68:339.

Evans, H.E., and C.M. Yoshimoto. 1962. The ecology and nesting behavior of the Pompilidae (Hymenoptera) of the northeastern United States. Miscellaneous Publications of the Entomological Society of America 3:65-119.

Falk, S.J. 1997. Cryptocheilus notatus (Rossi, 1792) (Species Profile). Available online at http://www.bwars.com/index,php?q=wasp/pompilidae/pepsinae/cryptocheilus-notatus. Acccessed 27 February 2016. [photograph by J. Early].

Ganz, R. 2009. Wasp that hunts crab spiders? Available online at http://www.bugguide.net/ node/view/271399/bgimage. Accessed 8 August 2014.

Gerber, G.K. 2012. Spider wasp - Tachypompilus. Available online at http://www.bugguide. net/node/view/669283. Accessed 20 November 2014.

Gess, F.W., and S.K. Gess. 1980. Spider vanquishers: The nesting of Tachypompilus ignitus (Smith) and Batazonellus fuliginosus (Klug). The Eastern Cape Naturalist 69:4-7. 
Gluth, J. 2014. Predatory wasp with spider. Available online at http://www.bugguide.net/ node/view/932911/bgimage. Accessed 12 October 2014.

Go, H. 2014. Spider wasp with spider - female. Available online at http://www.bugguide. net/node/view/968289/bgimage. Accessed 13 October 2015.

Goodman, A. 2011. Spider wasp vs. crab spider over paralyzed salticid. Available online at http://www.bugguide.net/node/view/537739/bgimage. Accessed 6 June 2015.

Grandi, G. 1961. Studi di un Entomologo sugli Imenotteri superiori. Bolletino dell' Istituto di Entomologia delia Universita degli Studi di Bologna 25:1-659.

Greenberg, J. 2016. Spider wasp with spider - female. Available online at http://www.bugguide.net/node/view/1260676, 1260677/bgimage. Accessed 23 July 2016.

Griffin, J.S. 2014. Pelee island wasp/spider. Available online at http://www.bugguide.net/ node/view/984510/bgimage. Accessed 6 June 2015.

Gros, E., and F. Durand. 2013. Les Pompiles. Comportement/Clé des Genres. Bulletin de 1' Association Entomologique d' - Arvernsis-Hors Série n 1:1-183.

Gross, J. 2005. Spider wasp - Anoplius americanus. Available online at http://www.bugguide.net/node/view/45509. Accessed 28 September 2013.

Gwynne, D.I. 1979. Nesting biology of the spider wasps (Hymenoptera:Pompilidae) which prey on burrowing wolf spiders (Araneae, Lycosidae, Geolycosa). Journal of Natural History 13:681-692.

Hankey, P. 2005. Spider being hauled away by an insect - Agenioideus humilis. Available online at http://www.bugguide.net/node/view/224646/bgimage. Accessed 6 June 2015.

Harris, A.C. 1999. The life histories and nesting behavior of the Pompilidae (Hymenoptera) in New Zealand: A comparative study. Species Diversity 4:143-235.

Hart, G.V. 2009. Spider wasp - Pompilidae. Available online at http://www.bugguide.net/ node/view/286863. Accessed 16 October 2015.

Hemberger, R. 2006. Spider wasp. Psorthaspis planata. Available online at nathistoc.bio. uci.edu/hymenopt/Psorthaspis planata.htm. Accessed 10 October 2013.

Hemberger, R. 2013. Spider wasp. Anoplius americanus. Available online at nathistoc.bio. uci.edu/hymenopt/Anoplius americanus/index.htm. Accessed 10 October 2013.

Hobo Joe A.K.A. Insect Lover (O. Davids). 2016. Wasp vs spider. Available online at http:// www.bugguide.net/node/view/1230737/bgimage. Accessed 9 June 2016.

Houston, S. 2009. Spider wasp. Available online at http://www.bugguide.net/node/ view/329786/bgimage. Accessed 21 October 2014.

Hughes, W. 2008. There goes the neighborhood [general]. 5 August 2008. Available online at http://www.sparkleberrysprings.com/v-web/b2/index.php?s-pisaurina. Re-accessed 31 July 2014.

Huntley-Franck, P. 2008. Wasp and dinner - Priocnemis. Available online at http://www. bugguide.net/node/view/227247/bgimage. Accessed 6 August 2014.

Huntley-Franck, P. 2009. Priocnemis oregona? with foldingdoor spider. Available online at http://www.bugguide.net/node/view/264522/bgimage. Accessed 2 August 2014.

Hurd, P.D., Jr. 1952. Revision of the Nearctic species of the pompilid genus Pepsis (Hymenoptera: Pompilidae). Bulletin of the American Museum of Natural History 98:257-334.

Insinga, J. 2012. Spider hawk w/prey - Episyron biguttatus - female. Available online at http://www.bugguide.net/node/view/609165/bgimage. Accessed 3 October 2013.

Isley, E. 2014. Spider wasps (Family Pompilidae) observed by ericisley. Available online at http://www.inaturalist.org/observations/811429. Accessed 1 August 2014.

Ivanov, S. 2015. Unknown spider wasp with prey - Geolycosa - female. Available online at http://www.bugguide.net/node/view/1143534/bgimage. Accessed 31 August 2016.

Ivanov, S. 2016a. Very small spider wasp with spider - female. Available online at http://www. bugguide.net/node/view/1297802 - 1297805/bgimage. Accessed 28 September 2016. 
Ivanov, S. 2016b. Spider wasp Anoplius? - female. Available online at http://www.bugguide.net/node/view/1283370/bgimage. Accessed 31 August 2016.

Ivanov, S. 2016c. Spider wasp Anoplius? - female. Available online at http://www.bugguide.net/node/view/1294836 - 1294840, 1295269-1295273/bgimage. Accessed 21 September 2016.

Iwata, K. 1942. Comparative studies on the habits of solitary wasps (translated from Japanese). Tenthredo 4:1-146.

Iwata, K. 1964. Bionomics of non-social wasps in Thailand. Nature and Life in Southeast Asia 3:323-383.

Iwata, K. 1976. Evolution of Instinct. Comparative Ethology of Hymenoptera (translated from Japanese). Smithsonian Institution and the National Science Foundation, Washington, DC. 535 pp.

Janvier, H. (M.F. Claude-Joseph). 1930. Recherches biologiques sur les prédateurs du Chili. Annales des Sciences Naturelles (10) 13:235-354.

Johnson, S.R. 2016. Small Melissodes male. Available online at http://www.bugguide.net/ node/view/1280421/bgimage. Accessed 26 August 2016.

Johnston, G. 2016. Wasp preying on spider. Available online at http://www.bugguide.net/ node/view/1280056/bgimage. Accessed 26 August 2016.

Kaston, B.J. 1948. Spiders of Connecticut. State Geological and Natural History Survey of Connecticut Bulletin 70:1-874.

KC Wildlife. 2013. Black/blue wasp dragging spider across sand. Available online at http:// www.bugguide.net/node/view/851375/bgimage. Accessed 2 August 2014.

Kelly, R. 2013. Wasp A - unident - Priocnemis minorata. Available online at http://www. bugguide.net/node/view/764615/bgimage. Accessed 10 October 2013.

Kiely, A. 2009. Tarantula hawk wasp and tarantula - Pepsis mildei - female. Available online at http://www.bugguide.net/node/view/332495/bgimage. Accessed 1 August 2016.

Klein, T. 2011. Episyron biguttatus? - Episyron biguttatus. Available online at http://www. bugguide.net/node/view/697295/bgimage. Accessed 17 October 2015.

Kouri, J. D. 2009. Blue-black spider wasp - Anoplius - female. Available online at http:// www.bugguide.net/node/view/601530. Accessed 30 August 2015.

Krombein, K.V. 1979. Family Pompilidae. Pp. 1523-1570, In K.V. Krombein, P.D. Hurd Jr., D.R. Smith, and B.D. Burks (Eds.). Catalog of Hymenoptera in America North of Mexico. Volume 2, Apocrita (Aculeata). Smithsonian Institution Press, Washington, DC.

Krombein, K.V. 1991. Biosystematic Studies of Ceylonese Wasps, XIX: Natural History Notes on Several Families (Hymenoptera: Eumenidae, Vespidae, Pompilidae, and Crabronidae). Smithsonian Institution Press, Washington, DC. 41 pp.

Krombein, K.V., and B.B. Norden. 1996. Behavior of nesting Episyron conterminus posterus (Fox) and its cleptoparasite Ephuta s. slossonae (Fox) (Hymenopera: Pompilidae, Mutillidae). Proceedings of the Entomological Society of Washington 98:188-194.

Kurczewski, F.E. 1975. Host records for some species of Pompilidae from the southwestern United States and Mexico (Hymenoptera). Pan-Pacific Entomologist 51:147-151.

Kurczewski, F.E. 1981. Observations on the nesting behaviors of spider-wasps in southern Florida (Hymenoptera: Pompilidae). Florida Entomologist 64:424-437.

Kurczewski, F.E. 1989. Ecology, mating, and nesting of Tachypompilus ferrugineus nigrescens (Hymenoptera: Pompilidae). Great Lakes Entomologist 22:75-78.

Kurczewski, F.E. 2001. Comparative nesting behavior of Episyron quinquenotatus (Hymenoptera: Pompilidae) in the northeastern United States. Northeastern Naturalist 8:403-426.

Kurczewski, F.E. 2010. Prey and nesting behavior of some North American spider wasps (Hymenoptera: Pompilidae). Northeastern Naturalist 17:115-124. 
Kurczewski, F.E., and G.B. Edwards. 2012. Hosts, nesting behavior, and ecology of some North American spider wasps (Hymenoptera: Pompilidae). Southeastern Naturalist 11 (Monograph 4):1-71.

Kurczewski, F.E., and D.H. Kiernan. 2015. Analysis of spider wasp host selection in the eastern Great Lakes Region (Hymenoptera: Pompilidae). Northeastern Naturalist 22 (Monograph 11):1-88.

Kurczewski, F.E., and E.J. Kurczewski. 1968a. Host records for some North American Pompilidae (Hymenoptera) with a discussion of factors in prey selection. Journal of the Kansas Entomological Society 41:1-33.

Kurczewski, F.E., and E.J. Kurczewski. 1968b. Host records for some North American Pompilidae (Hymenoptera). First Supplement. Journal of the Kansas Entomological Society 41:367-382.

Kurczewski, F.E., and E.J. Kurczewski. 1972. Host records for some North American Pompilidae, Second Supplement. Tribe Pepsini. Journal of the Kansas Entomological Society 45:181-193.

Kurczewski, F.E., and E.J. Kurczewski. 1973. Host records for some North American Pompilidae (Hymenoptera). Third Supplement. Tribe Pompilini. Journal of the Kansas Entomological Society 46:65-81.

Kurczewski, F.E., and M.F. O'Brien. 1991. Auplopus carbonarius, a Palearctic spider wasp, extends its range to Michigan (Hymenoptera: Pompilidae). Great Lakes Entomologist 24:185-186.

Kurczewski, F.E., and N.F.R. Snyder. 1964. Observations on the nesting of Pompilus (Ammosphex) michiganensis (Dreisbach) (Hymenoptera: Pompilidae). Proceedings of the Biological Society of Washington 77:215-222.

Kurczewski, F.E., and M.G. Spofford. 1985. Observations on the nesting and unique cachement behavior of Calicurgus hyalinatus (Hymenoptera: Pompilidae). Great Lakes Entomologist 18:41-44.

Kurczewski, F.E., and M.G. Spofford. 1986. Observations on the behaviors of some Scoliidae and Pompilidae (Hymenoptera) in Florida. Florida Entomologist 69:636-644.

Kurczewski, F.E., E.J. Kurczewski, and R.A. Norton. 1987. New prey records for Nearctic species of Pompilidae (Hymenoptera). Journal of the Kansas Entomological Society 60:467-475.

Kurczewski, F.E., J.P. Pitts, and N.B. Elliott. 2014. Annotated list of spider wasps from The Bahamas, with description of a new species of Tachypompilus (Hymenoptera: Pompilidae). Caribbean Naturalist 5:1-28.

Lampkin, J. 2015. Spider wasp with prey - Entypus unifasciatus - female. Available online at http://www.bugguide.net/node/view/1105313/bgimage. Accessed 23 July 2015.

Lampkin, J. 2016. Lycosidae as prey - ID request. Available online at http://www.bugguide. net/node/view/1263575/bgimage. Accessed 25 July 2016.

Lasley, G. 2014. Red-tailed Spider Hunter (Tachypompilus ferrugineus). Available online at http://www.inaturalist/observations/811169. Accessed 1 August 2014.

Lenhart, P. A. 2010. Basket case parasitoid - Ageniella - female. Available online at http:// www.bugguide.net/node/view/548098,548100,548101/bgimage. Accessed 22-23 October 2014 .

LilWeezyAnna. 2013. Pompillidae [sic!] - female. Available online at http://www.bugguide. net/node/view/856885/bgimage. Accessed 2 August 2014.

Macmillan, A.S. 2014. Blue wasp eating spider - Auplopus architectus. Available online at http://www.bugguide.net/node/view/982518/bgimage. Accessed 16 October 2015.

Martin-Hall. 2016. Unknown (placeholder: Tachypompilus ferrugineus). Available online at https://www.inaturalist.org/observations/3703893. Accessed 20 August 2016. 
Martins, R.P. 1991. Nesting behavior and prey of Poecilopompilus algidus fervidus and Tachypompilus xanthopterus (Hymenoptera: Pompilidae). Journal of the Kansas Entomological Society 64:231-236.

Mayfly 1963. 2015. Red-tailed Spider Hunter (Tachypompilus ferrugineus). Available online at https://www.inaturalist.org/observations/1781179. Accessed 20 August 2016.

McIvor, M.D. 2013. Pompilidae. Available online at http://www.bugguide.net/node/ view/862012/bgimage. Accessed 14 October 2015.

McKechnie, S. 2013. Wasp with Xysticus 170813. Available online at http://www.bugguide. net/node/view/1005913/bgimage. Accessed 11 October 2014.

McQueen, D.J. 1978. Field studies of growth, reproduction, and mortality in the burrowing wolf-spider Geolycosa domifex (Hancock). Canadian Journal of Zoology 56:2037-2049.

Melton, C.W. 2008. Tarantula hawk wasp, Pepsis sp., with paralyzed tarantula - Pepsis mildei - female. Available online at http://www.bugguide.net/node/view/199871/bgimage. Accessed 1 August 2016.

Melton, C.W. 2009. Spider wasp with prey - female. Available online at http://www.bugguide.net/node/view/259667/bgimage. Accessed 8 August 2014.

Micallef, C. 2012. TX - Spider killing wasp? - Poecilopompilus interruptus. Available online at http://www.bugguide.net/node/view/652587/bgimage. Accessed 2 October 2013.

Miller, E. 2016. Wasp - Caliadurgus fasciatellus - female. Available online at http://www. bugguide.net/node/view/1257976/bgimage. Accessed 15 July 2016.

Moniotte, P. 2011. Pompilidae - Anoplius - female. Available online at http://www.bugguide.net/node/view/611054/bgimage. Accessed 29 September 2013.

Montgomery, G. 2010. Wasp - Auplopus mellipes. Available online at http://www.bugguide. net/node/view/728534/bgimage. Accessed 23 July 2014.

Moran, M. 2004. Anoplius sp. with prey - Anoplius - female. Available online at http://www. bugguide.net/node/view/4355/bgimage. Accessed 22 July 2014.

Morris, R. 2009. Tarantula hawk yellow antenna? Confused on spider? - female. Available online at http://www.bugguide.net/node/view/350527. Accessed 4 October 2013.

Murray, P. 2015. Pompillidae [sic!]. Available online at http://www.bugguide.net/node/ view/1133828/bgimage. Accessed 27 October 2015.

Murray, T. 2011. Spider wasp - Priocnemis - female. Available online at http://www.bugguide.net/node/view/560878. Accessed 10 October 2013.

Murray, T. 2014a. Spider wasp - female. Available online at http://www.bugguide.net/node/ view/981112. Accessed 26 October 2014.

Murray, T. 2014b. Spider wasp - female. Available online at http://www.bugguide.net/node/ view/981111. Acessed 28 October 2014.

Nakao, S., and K. Iwata. 1964. Notes on the provisioning habits of some solitary hunting wasps of Southeast Asia (Hymenoptera, Aculeata) (in Japanese). Kontyu 32:504-511.

Naturenut. 2014. Red-tailed Spider Hunter (Tachypompilus ferrugineus). Available online at http://www.inaturalist.org/observations/748116. Accessed 1 August 2014.

Neuman, A. 2016. Gwasp - Priocnemis minorata. Available online at http://www.bugguide. net/node/view/1223222/bgimage. Accessed 22 June 2016.

Nick. 2016. Spider wasp preys upon wolf spider. Available online at http://www.whatsthatbug.com/2016/08/03/spider-wasp-preys-upon-wolf-spider. Accessed 23 August 2016.

Nolfo, S. 1983. Notes on Auplopus carbonarius, a spider wasp new to the United States (Hymenoptera: Pompilidae). Entomological News 94: 29-30.

Padelford, L., and B. Padelford. 2013. Spider wasp with spider - Phanagenia bombycina - female. Available online at http://www.bugguide.net/node/view/801362/bgimage. Accessed 24 July 2015. 
Padelford, L., and B. Padelford. 2015. Pompilid wasps? - Priocnemis minorata - female. Available online at http://www.bugguide.net/node/view/1057523, 1057524. Accessed 8 June 2015.

Paulson, D., and E. Paulson. 2015. Antrodiatus pacificus? - Priocnemis oregona. Available online at http://www.bugguide.net/node/view/ 1051243, 1051244, 1051246/bgimage. Accessed 6 June 2015.

Pearson, J. 2011. Spider wasp - Priocnemis oregona - female. Available online at http:// www.bugguide.net/node/view/526972/bgimage. Accessed 6 August 2014.

Penner, S. 2010. Bug wars - Episyron. Available online at http://www.bugguide.net/node/ view/443641/bgimage. Accessed 8 August 2014.

Platnick, N. 2015. The World Spider Catalog, version 16.5, American Museum of Natural History. Available online at http://www.research.amnh.org/iz/spiders/catalog/. Accessed 10 August 2015.

Punzo, F. 1994a. The biology of the spider wasp, Pepsis thisbe (Hymenoptera: Pompilidae) from Trans Pecos, Texas. I. Adult morphometrics, larval development and the ontogeny of larval feeding patterns. Psyche 101:229-242.

Punzo, F. 1994b. The biology of the spider wasp, Pepsis thisbe (Hymenoptera: Pompilidae) from Trans Pecos, Texas. II. Temporal patterns of activity and hunting behavior with special reference to the effects of experience. Psyche 101:243-256.

Ransom, R. 2013. Black wasp on the way to stash the morning's victim - Anoplius. Available online at http://www.bugguide.net/node/view/787151. Accessed 2 October 2013.

Reynolds, B.E. 2005. Spider wasp with Nursery Web Spider - female. Available online at http://www.bugguide.net/node/view/696876/bgimage. Accessed 2 August 2014.

Reynolds, B.E. 2015a. Spider wasp with prey - Poecilopompilus interruptus - female. Available online at http://www.bugguide.net/node/view/1143396/bgimage. Accessed 23 September 2015.

Reynolds, B.E. 2015b. Spider wasp with prey - Anoplius Lepidus - female. Available online at http://www.bugguide.net/node/view/1141139/bgimage. Accessed 21 September 2015.

Richards, O.W., and A.H. Hamm. 1939. The biology of the British Pompilidae. Transactions of the Society for British Entomology 6:51-114.

Riley, D.R. 2013. Poecilopompilus algidus. Available online at http://www.bugguide.net/ node/view/828955/bgimage. Accessed 20 September 2013.

Roble, S.M. 1985. Submergent capture of Dolomedes triton (Araneae, Pisauridae) by Anoplius depressipes (Hymenoptera, Pompilidae). Journal of Arachnology 13:391-392.

Schade, S. 2015. Spider wasp sp. dragging wolf spider?? Available online at http://www. bugguide.net/node/view/1102637/bgimage. Accessed 21 July 2015.

Scharf, P.A. 2013. Spider wasp - Tachypompilus ferrugineus. Available online at http:// www.bugguide.net/node/view/812944/bgimage. Accessed 20 September 2013.

Schneider, K. 2015. Pompilidae? Available online at http://www.bugguide.net/node/ view/1143251/bgimage. Accessed 23 September 2015.

Schusteff, A. 2013. Pepsine wasp and wolf spider - female. Available online at http://www. bugguide.net/node/view/869374/bgimage. Accessed 25 November 2013.

Shelton, J. 2015. Spider wasp - Priocnemis minorata - female. Available online at http:// www.bugguide.net/node/view/1056703, 1056704. Accessed 8 June 2015.

Sipolandis. 2013. Wasp and spider, Utah - Poecilopompilus. Available online at http://www. bugguide.net/node/view/844798/bgimage. Accessed 19 July 2014.

Smith, J.M. 2009. Big Thicket critters: Entypus unifasciatus. Available online at http:// www.bigthicketcritters.com/images/Fullsize/fsWASP45.jpg. Accessed 20 July 2014.

Smith, N. 2006. Episyron sp. \#3756. Available online at http://www.pbase.com/naomismith/image/64914623. Accessed 4 December 2013. 
Smith, N. 2008. Priocnemis cornica. Available online at http://www.pbase.com/naomismith/priocnemis_cornica. Accessed 2 December 2013.

Smith, N. 2009a. Wasp ID Confirmation - Priocnemis. Available online at http://www.bugguide.net/node/view/335804/bgimage. Accessed 6 August 2014.

Smith, N. 2009b. Priocnemis? Available online at http://www.bugguide.net/node/ view/309061. Accessed 23 October 2014.

Smith, N. 2010a. \#8840, 8865, 8873, 8874 JN10. Available online at http://www.pbase. com/naomismith/image/127721010, 127721568, 127721640, 127221703. Accessed 4 December 2013.

Smith, N. 2010b. JL10 \#0119. Available online at http://www.pbase.com/naomismith/image/127932283 and on http://www.bugguide.net/node/view/420540, 420541. Accessed 5 December 2013 and 10 November 2014, respectively.

Smith, N. 2012a. Wasp. Available online at http://www.bugguide.net/node/view/654165/ bgimage. Accessed 12 October 2014.

Smith, N. 2012b. Wasp and spider - Auplopus carbonarius. Available online at http://www/ bugguide.net/node/view/765944. Accessed 19 September 2014.

Smith, N. 2016. Wasp and spider - Auplopus carbonarius. Wasp JL 16 \#9226. Available online at http://www.pbase.com/image/163788189, 163788190, 164042295. Accessed 8-9 September 2016.

Snider, R. 2008. Tarantula hawk wasp - Pepsis. Available online at http://www.bugguide. net/node/view/297984/bgimage. Accessed 25 July 2015.

Speer, R.J. 2015. Unknown wasp - genus/species? Available online at http://www.bugguide. net/node/view/1115976/bgimage. Accessed 8 August 2015.

Swanson, M. 2015. Spider wasp with prey (close up of spider) - female. Available online at http://www.bugguide.net/node/view/1107908/bgimage. Accessed 24 July 2015.

Taogirl (J.L. Sikora). 2013. Red-tailed Spider Hunter, Tachypompilus ferrugineus. Available online at http://www.inaturalist.org/observations/359833. Accessed 20 September 2013.

Thysse, A. 2013a. Adrian Thysse. Photography/Dipogon sayi. Available online at http:// www.adrianthyssephotography.zenfolio.com/p537899560/hfle8117\#hfle8117. Accessed 31 October 2013.

Thysse, A. 2013b. Splendour awaits: Wasp and spider. Available online at http://www.bugs. adrianthysse.com/2013/03/wasp-and-spider/. Accessed 18 October 2013.

Townes, H. 1957. Nearctic wasps of the subfamilies Pepsinae and Ceropalinae. United States National Museum Bulletin 209:1-286.

Trammel, E. 2006. Pompilid - Priocnemis minorata. Available online at http://www.bugguide.net/node/view/70583. Accessed 10 October 2013.

Turner, T. 2015. Wasp with spider. Available online at http://www.bugguide.net/node/ view/1144762/bgimage. Accessed 26 September 2015.

Tyler, R.M., Jr. 2014. Spider wasp? - Poecilopompilus. Available online at http//www. bugguide.net/node/view/965120/bgimage, and http:/www.inaturalist.org/observations/809448, and https://www.flickr.com/photos/royalhillsphotography/14559288697/ in/photolist Accessed 9 August 2014.

VanDyk, J. 2011. Wasp with spider - Sericopompilus apicalis. Available online at: http:// www.bugguide.net/node/view/554408/bgimage. Accessed 11 July 2015.

Vardy, C.R. 2000. The New World tarantula-hawk wasp genus Pepsis Fabricius (Hymenoptera: Pompilidae). Part 1. Introduction and the P. rubra species-group. Zoologische Verhandeling Leiden 332:1-86.

Villalobos, T.P. 2009. Wasp. Available online at http://www.bugguide.net/node/ view/286472/bgimage. Accessed 2 August 2014. 
Waayers, R. 2006. Tarantula hawk with tarantula - Pepsis mildei - female. Available online at http://www.bugguide.net/node/view/83146/bgimage. Accessed 1 August 2016.

Waichert, C., C.D. von Dohlen, and J.P. Pitts. 2011. Does the Ageniella accepta speciesgroup (Hymenoptera: Pompilidae) contain multiple species or a single, wide-ranging, morphologically variable species? Entomological Society of America Meetings Online Program, 15 November 2011. Available online at http://esa.confex.com/esa/2011/webprogram/Paper59756.html. Accessed 14 March 2012.

Walton, R.K. 2013. Natural history services. Wasps. Pompilidae 6. Available online at http://www.rkwalton.com/wasps.php. Accessed 29 November 2013.

WanderingMogwai (D.J.G. Leffler). 2015a. Wasp and spider. Available online at http:// www.bugguide.net/node/view/1124906/bgimage. Accessed 21 August 2015.

WanderingMogwai (D.J.G. Leffler). 2015b. Spider wasp. Available online at http://www. bugguide.net/node/view/1157987/bgimage. Accessed 23 October 2015.

Wasbauer, M.S. 1955. Observations on the biology of Anoplius fulgidus Cresson (Hymenoptera: Pompilidae). Pan-Pacific Entomologist 15:81-92.

Wasbauer, M.S. 1957. A biological study of Anoplius (Anoplius) imbellis Banks (Hymenoptera: Pompilidae). Wasmann Journal of Biology 15:81-97.

Wasbauer, M.S. 1982. Prey records for some North American spider wasps (Hymenoptera: Pompilidae). Pan-Pacific Entomologist 58:223-230.

Wasbauer, M.S., and L.S. Kimsey. 1985. California spider wasps of the subfamily Pompilinae (Hymenoptera: Pompilidae). Bulletin of the California Insect Survey 26:1-130.

Wei, M. 2012. Spider wasp drags Cat-Faced Spider, digs burrow (Parts 1-3). Available online at http://www.youtube.com/watch?v=DqtnSoe9GLA, 6goOrPsmZwo, pnSrKSBMs9Q. Accessed 11 October 2013.

Wei, M. 2013. Parasitoid wasp drags off prey. Available online at http://www.youtube.com/ watch?v=zAcoUOYCbiM. Accessed 11 October 2013.

White, S.L. 2010. Foothills fancies. Nature today: Attempted prey piracy. Available online at http://www.foothillsfancies.blogspot.com/2010/07/nature-today-attempted-preypiracy.html. Accessed 30 July 2014.

Williams, F.X. 1919. Philippine wasp studies. Bulletin of the Hawaiian Sugar Planters' Experiment Station, Entomological Series 14:19-181.

Williams, F.X. 1928. Studies in tropical wasps - their hosts and associates (with descriptions of new species). Bulletin of the Experiment Station of the Hawaiian Sugar Planter's Association (Entomology) 19:1-179.

Wilson, C. 2015. Who's the predator? - Dipogon. Available online at http://www.bugguide. net/node/view/1102342/bgimage. Accessed 15 Auguat 2015.

Wilson, J.S., and J.P. Pitts. 2007. New host associations for New World spider wasps (Hymenoptera: Pompilidae). Journal of the Kansas Entomological Society 80:223-228.

Wilson, W.H. 2014. Parasitoid wasp attacking lycosid spider. Available online at http:// www.bugguide.net/node/view/992916/bgimage. Accessed 2 June 2015.

Zaremba, B. 2008a. Wasp dragging spider - can either be ID'ed? Available online at http:// www.bugguide.net/node/view/221635/bgimage. Accessed 28 July 2015.

Zaremba, B. 2008b. Spider wasps? - female. Available online at http://www.bugguide.net/ node/view/248903/bgimage. Accessed 8 August 2014. 
Appendix 1. Host-spider index for species of Pompilidae included in this study. Families of spiders and species of Pompilidae are listed taxonomically following Platnick (2015) and Krombein (1979), respectively, with species of spiders arranged alphabetically.

\section{ANTRODIAETIDAE}

Antrodiaetus sp.: Priocnemis (Priocnemissus) oregona Banks.

\section{EUCTENIZIDAE}

Aptostichus simus Chamberlin: Aporus (Plectraporus) hirsutus (Banks).

\section{THERAPHOSIDAE}

Aphonopelma ?anax (Chamberlin): Pepsis sp.

Aphonopelma chalcodes Chamberlin: Pepsis mildei Stål.

Aphonopelma ?harlingenum (Chamberlin): Pepsis sp.

Aphonopelma hentzi (Girard): Pepsis sp.

Aphonopelma steindachneri (Ausserer): Pepsis mildei.

\section{SEGESTRIIDAE}

Segestria sp.: Arachnospila arcta (Cresson).

\section{DYSDERIDAE}

Dysdera crocata C.L. Koch: Priocnemis (Priocnemissus) minorata Banks.

\section{ARANEIDAE}

Araneidae sp.: Caliadurgus fasciatellus alienatus (Smith), Episyron biguttatus californicus (Banks), Episyron conterminus cressoni (Dewitz), Episyron quinquenotatus hurdi Evans. Araneus gemmoides Chamberlin \& Ivie: Episyon biguttatus californicus, Episyron quinquenotatus hurdi.

Araneus marmoreus Clerck: Episyron ?q. quinquenotatus (Say).

Araneus montereyensis (Archer): Episyron quinquenotatus hurdi.

Araneus pegnia (Walckenaer): Agenioideus (Agenioideus) humilis (Cresson).

Araneus saevus (L. Koch): Episyron b. biguttatus (Fabricius).

Araneus sp.: Agenioideus (Agenioideus) humilis.

Argiope trifasciata (Fôrskal): Episyron b. biguttatus, Poecilopompilus algidus coquilletti

(Provancher).

Eriophora ravilla (C.L. Koch): Poecilopompilus a. algidus (Smith).

Eustala anastera (Walckenaer): Agenioideus (Agenioideus) humilis, Poecilopompilus i. interruptus (Say).

Larinia directa (Hentz): Caliadurgus fasciatellus alienatus.

Larinioides cornutus (Clerck): Episyron b. biguttatus.

Larinioides patagiatus (Clerck): Episyron b. biguttatus.

Metepeira labyrinthea (Hentz): Caliadurgus fasciatellus alienatus.

Metepeira spinipes F.O. Pickard-Cambridge: Episyron quinquenotatus hurdi.

Neoscona arabesca (Walckenaer): Agenioideus (Agenioideus) humilis, Episyron b. biguttatus.

Neoscona crucifera (Lucas): Agenioideus (Agenioideus) humilis, Episyron b. biguttatus, Poecilopompilus a. algidus, Poecilopompilus $i$. interruptus.

Neoscona oaxacensis (Keyserling): Episyron biguttatus californicus, Episyron quinquenotatus hurdi x Episyron q. quinquenotatus intergrade. 
Zygiella x-notata (Clerck): Agenioideus (Agenioideus) humilis, Episyron quinquenotatus hurdi.

\section{LYCOSIDAE}

Alopecosa aculeata (Clerck): Cryptocheilus attenuatus Banks.

Alopecosa kochi (Keyserling): Phanagenia bombycina (Cresson), Arachnospila arcta.

?Alopecosa kochi: Arachnospila f. fumipennis Zetterstedt.

Arctosa littoralis (Hentz): Anoplius (Lophopompilus) cleora Banks, Anoplius (Arachnophroctonus) americanus ambiguus (Dahlbom), Anoplius (Arachnophroctonus) apiculatus autumnalis (Banks).

Arctosa ?rubicunda (Keyserling): Priocnemis (Priocnemissus) minorata.

?Arctosa sp.: Ageniella (Ageniella) conflicta Banks.

Geolycosa wrighti (Emerton): Anoplius (Arachnophroctonus) semicinctus (Dahlbom), Arachnospila scelesta (Cresson).

Gladicosa gulosa (Walckenaer): Priocnemis (Priocnemissus) minorata.

Hogna antelucana (Montgomery): Entypus unifasciatus cressoni (Banks), Tachypompilus ferrugineus annexus (Banks).

Hogna carolinensis (Walckenaer): Entypus aratus (Townes), Tachypompilus f. ferrugineus (Say).

Hogna fondicola (Emerton): Priocnemis (Priocnemissus) minorata.

Hogna ?lenta (Hentz): Tachypompilus f. ferrugineus.

?Hogna sp.: Anoplius (Lophopompilus) atrox (Dahlbom).

Lycosidae sp.: Phanagenia bombycina.

Pardosa ?lapidicina Emerton: Anoplius (Anoplius) ithaca (Banks).

Pardosa moesta Banks: Priocnemis (Priocnemis) cornica (Say).

Pardosa sp.: Priocnemis (Priocnemissus) minorata, Ammosphex a. angularis (Banks).

Pardosa ?xerampelina (Keyserling): Anoplius (Anoplius) ithaca.

Rabidosa punctulata (Hentz): Ageniella (Ageniella) accepta (Cresson) or A. (A.) conflicta, Tachypompilus $f$. ferrugineus, Anoplius (Lophopompilus) aethiops (Cresson), Anoplius (Notiochares) lepidus atramentarius (Dahlbom), Anoplius (Anoplius) fulgidus (Cresson).

Rabidosa rabida (Walckenaer): Entypus fulvicornis (Cresson), Entypus u. unifasciatus (Say), Phanagenia bombycina, Tachypompilus ferrugineus annexus, Tachypompilus $f$. ferrugineus, Anoplius (Lophopompilus) atrox.

Schizocosa avida (Walckenaer): Tachypompilus $f$. ferrugineus.

Schizocosa ?mccooki Montgomery: Tachypompilus u. unicolor (Banks).

Schizocosa ?ocreata (Hentz): Anoplius (Arachnophroctonus) nigritus (Dahlbom).

Schizocosa sp.: Priocnemis (Priocnemissus) minorata.

Tigrosa annexa (Chamberlin): Anoplius (Arachnophroctonus) americanus ambiguus.

Tigrosa ?georgicola (Walckenaer): Entypus u. unifasciatus.

Tigrosa grandis (Banks): Entypus u. unifasciatus, Tachypompilus f. ferrugineus, T. $и$. unicolor.

Tigrosa helluo (Walckenaer): Entypus u. unifasciatus, Tachypompilus f. ferrugineus, Anoplius (Lophopompilus) aethiops, Anoplius (Anoplius) illinoensis (Robertson) or A. (A.) ventralis (Banks).

Cf. Tigrosa helluo: Tachypompilus $f$. ferrugineus.

?Tigrosa helluo: Anoplius (Anoplius) virginiensis (Cresson).

?Tigrosa sp.: Anoplius (Lophopompilus) atrox.

Trochosa ruricola (De Geer): Priocnemis (Priocnemissus) minorata, Priocnemis (Priocnemis) cornica, Anoplius (Anoplius) imbellis Banks, Anoplius (Anoplius) virginiensis. 
Trochosa sp.: Priocnemis (Priocnemissus) minorata, Anoplius (Pompilinus) marginatus (Say) species-complex, Anoplius (Pompilinus) tenebrosus (Cresson).

Trochosa sp., probably ruricola: Anoplius (Anoplius) imbellis.

Trochosa terricola Thorell: Priocnemis (Priocnemissus) minorata, Priocnemis (Priocnemis) cornica, Anoplius (Pompilinus) marginatus species-complex, Anoplius (Anoplius) imbellis, Anoplius (Anoplius) virginiensis.

Varacosa avara (Keyerling): Anoplius (Arachnophroctonus) semirufus (Cresson).

\section{PISAURIDAE}

Dolomedes albineus Hentz: Entypus u. unifasciatus.

Dolomedes scriptus Hentz: Tachypompilus $f$. ferrugineus.

Dolomedes tenebrosus Hentz: Entypus fulvicornis, Entypus u. unifasciatus, Tachypompilus f. ferrugineus, Anoplius (Lophopompilus) atrox.

Dolomedes triton (Walckenaer): Anoplius (Anoplius) depressipes Banks.

Pisaurina mira (Walckenaer): Priocnemis (Priocnemissus) minorata, Priocnemis (Priocnemis) germana, Anoplius (Anoplius) depressipes.

\section{OXYOPIDAE}

Oxyopes salticus Hentz: Ageniella (Priophanes) arcuata (Banks).

\section{AGELENIDAE}

Agelenopsis sp.: Priocnessus nebulosus (Dahlbom), Anoplius (Anoplius) illinoensis or A. (A.) ventralis.

Eratigena agrestis (Walckenaer): Arachnospila arcta.

Hololena ?curta (McCook): Anoplius (Anoplius) fulgidus.

Hololena sp.: Arachnospila arcta.

Novalena pina Chamberlin \& Ivie: Arachnospila arcta.

\section{AMAUROBIIDAE}

Amaurobiidae sp.: Anoplius (Pompilinus) ?splendens (Dreisbach).

Callobius bennetti (Blackwall): Dipogon (Deuteragenia) papago anomalus Dreisbach.

Coras sp., possibly juvenilis (Keyserling): Priocnemis (Priocnemissus) minorata.

?Coras sp.: Anoplius (Lophopompilus) carolina (Banks).

Wadotes hybridus (Emerton): Priocnemis (Priocnemissus) minorata.

?Wadotes sp.: Anoplius (Lophopompilus) carolina.

\section{TENGELLIDAE}

Socalchemmis shantzi Platnick \& Ubick: Ammosphex s. solonus (Banks).

\section{EUTICHURIDAE}

Cheiracanthium inclusum (Hentz): Priocnemis (Priocnemis) germana, Priocnemis (Priocnemis) n. notha (Cresson), Auplopus mellipes variitarsatus (Dalla Torre).

Cheiracanthium mildei C.L. Koch: Priocnemis (Priocnemis) germana, Priocnemis (Priocnemis) n. notha, Auplopus carbonarius (Scopoli), Auplopus mellipes variitarsatus.

Cheiracanthium sp.: Priocnemis (Priocnemis) germana, Priocnemis (Priocnemis) scitula relicta Banks, Auplopus a. architectus (Say) x Auplopus architectus metallicus (Banks) intergrade. 
ANYPHAENIDAE

Anyphaena sp.: Priocnemis (Priocnemis) cornica, Auplopus a. architectus.

Anyphaenidae sp.: Auplopus architectus metallicus.

Hibana gracilis (Hentz): Auplopus a. architectus.

\section{LIOCRANIDAE}

?Agroeca sp.: Priocnemis (Priocnemis) cornica, Auplopus carbonarius.

\section{CLUBIONIDAE}

Clubiona lutescens Westring: Auplopus architectus metallicus.

Clubiona sp.: Auplopus m. mellipes (Say), Auplopus mellipes variitarsatus.

?Clubiona sp.: Priocnemis (Priocnemissus) minorata.

\section{TRACHELIDAE}

Trachelas tranquillus (Hentz): Auplopus a. architectus.

\section{GNAPHOSIDAE}

Herpyllus ecclesiasticus Hentz: Priocnemis (Priocnemis) germana.

Zelotes sp.: Anoplius (Pompilinus) tenebrosus.

\section{SPARASSIDAE (HETEROPODIDAE)}

Heteropoda venatoria L.: Tachypompilus $f$. ferrugineus.

\section{PHILODROMIDAE}

Philodromus sp.: Priocnemis (Priocnemis) cornica.

Thanatus sp., possibly formicinus (Olivier): Anoplius (Pompilinus) tenebrosus.

\section{THOMISIDAE}

Misumena vatia (Clerck): Auplopus a. architectus, Auplopus carbonarius.

Xysticus sp.: Priocnemis (Priocnemis) scitula relicta, Dipogon (Deuteragenia) c. calipterus

(Say), Dipogon (Deuteragenia) sayi nigrior Townes, Dipogon (Deuteragenia) s. sayi Banks, Anoplius (Pompilinus) tenebrosus, Perissopompilus phoenix Evans, Ammosphex m. michiganensis (Dreisbach).

\section{SALTICIDAE}

Anasaitis canosa (Walckenaer): Dipogon (Dipogon) g. graenicheri Banks.

Habronattus coecatus (Hentz) species group, possibly H. klauseri (Peckham \& Peckham): Aporinellus completus Banks.

Habronattus californicus (Banks) or H. peckhami (Banks): Aporinellus t. taeniolatus (Dalla Torre).

Maevia sp.: Auplopus caerulescens subcorticalis (Walsh).

Naphrys pulex (Hentz) or Sitticus sp.: Anoplius (Pompilinus) tenebrosus.

Phidippus arizonensis (Peckham \& Peckham): Auplopus m. mellipes.

Phidippus clarus Keyserling: Sericopompilus apicalis (Say), Sericopompilus neotropicalis

(Cameron), Anoplius (Pompilinus) marginatus species-complex.

Phidippus sp., possibly clarus: Auplopus mellipes variitarsatus.

Phidippus purpuratus Keyserling or P. purpuratus x P. ardens Peckham \& Peckham hybrid:

Aporinellus completus. 
Platycryptus undatus (De Geer): Priocnemis (Priocnemis) scitula relicta, Dipogon (Deuteragenia) pulchripennis (Cresson), Auplopus mellipes variitarsatus, Agenioideus (Gymnochares) birkmanni (Banks).

Salticidae sp.: Priocnemis (Priocnemis) scitula relicta. 